\title{
Congressional Intent, Practical Reasoning, and the Dynamic Nature of Federal Indian Law
}

\author{
Philip P. Frickey†
}

\begin{abstract}
Federal Indian law is a little understood, almost mysterious corner of public law. One major reason is that the Supreme Court has accorded Congress plenary power over Indian affairs. Taken to its logical conclusion, this doctrine would require the Court to follow congressional intent in deciding Indian law cases. The author demonstrates, however, that in a variety of important cases, the Court has subordinated original congressional intent in favor of more dynamic interpretation. Several eclectic factors explain these cases individually, but the factors are so deeply divisive that they cannot be aggregated into any general, descriptive theory of federal Indian law. This incoherence is in stark contrast to the conventional scholarly approach, which posits that the field is governed by foundationalist, deductive theory. Rejecting foundationalism, the author suggests an antiformalist alternative based on practical reasoning in law, which would stress a more inductive process based on context, traditions, and reasoning from paradigmatic cases. Practical reasoning not only better describes what the Court has done, but it is a normatively more attractive method of addressing the contemporary consequences of colonization. It could be a powerful tool not simply of demystification, but also of reconstruction.
\end{abstract}

\section{INTRODUCTION}

Near the beginning of this century, a Yale Law Journal article by Isaac Franklin Russell captured the dominant perceptions concerning the colonization of North America. ${ }^{1}$ The history was straightforward: "The Anglo-Saxon settled . . . to find a refuge from political oppression. His first wars were to maintain a foothold against savages, and later for self-defense and national integrity."2 Russell noted the speculation of anthropologists that "the Indian is undergoing a process of self-extermination," and that "if it was thought desirable to save the Indian to the civilization of the future," it might be best to assinnilate him gradually

$\dagger$ Professor of Law and Julius E. Davis Professor of Law for 1990-91, University of Minnesota. B.A. 1975, University of Kansas; J.D. 1978, University of Michigan. Robert Clinton, William Eskridge, Daniel Farber, Robert Gough, Nell Jessup Newton, Frank Pommersheim, and Gerald Torres provided helpful comments on an earlier version of this Article.

1. Russell, The Indian Before the Law, 18 YALE L.J. 328 (1909).

2. Id. at 329 . 
into American life. ${ }^{3}$ Turning to the legal domain, Russell concluded that the sovereignty of Indian tribes, though continuously recognized by the federal government under international law and through treaties and war, was "akin to the pious frauds of our early law, and our modern inethods of dealing with infants and mcoinpetents. At any rate, while we inay have deceived the Indian by our elaborate display of the forms of diplomacy, we have never deceived ourselves."

As this century draws to a close, the Indian is no longer the "Vanishing American," and tribal sovereignty, although fraught with ambiguity, is not an einpty legal fiction. ${ }^{6}$ Indians and their tribes have survived despite the drastic fits and starts of this century's federal Indian policy, which has twice cycled between coercing assimilation and encouraging tribal self-governinent. ${ }^{7}$ Each instance of policy oscillation resulted from a congressional decision to repudiate the approach of a past Congress. Even though the single specific constitutional grant of congressional power concerning Indians only authorizes the regulation of commerce with tribes, ${ }^{8}$ Congress has assumed nearly unfettered authority to govern Indian affairs.

3. Id. at 330 .

4. Id. at 333.

5. See generally B. Dippie, The Vanishing AmERICan: White AtTitudes and U.S. INDIAN POLICY (1982). Although the census data on the Native American population is "notoriously unrehable," it appears that the birth rate of Native Americans is twice the national average. See D. Getches \& C. Wilkinson, Federal Indian LAW: CASES ANd Materials 6 (2d ed. 1986).

6. Most recent Supreme Court Terms have witnessed several important cases involving tribal sovereignty. For example, the 1988 Term included Brendale v. Confederated Tribes \& Bands of Yakima Indian Nation, 109 S. Ct. 2994 (1989) (holding that tribc had authority to zone property owned by nonmembers only in those areas of the reservation traditionally closed to general public); Cotton Petroleuun Corp. v. New Mexico, 109 S. Ct. 1698 (1989) (holding that the state, like the tribe, could impose severance taxes on reservation oil produced under non-Indian leases); Mississippi Band of Choctaw Indians v. Holyfield, 109 S. Ct. 1597 (1989) (holding that state court lacked jurisdiction to enter adoption decree for tribal children even though parents had voluntarily surrendered children for adoption). On the prevalenee of Indian cases on the Court's docket, see C. WILKINSON, AMERICAN INDIANS, TIME AND THE LAW 2 (1987) (Court decided 12 Indian cases in 1960s, 35 in 1970s, and 32 during the first 7 Terms of the 1980s); Hellman, The Supreme Court, the National Law, and the Selection of Cases for the Plenary Docket, 44 U. PITT. L. REV. 521, 619 (1983) (during 1977-79 Terms, "[m]atters of Indian law . . . occupied the Court's time on a scale far out of proportion to the frequency of their appearance in the lower courts").

7. A quick overview should suffiee for our purposes. At the turn of this century, federal Indian policy was assimilatiomist in orientation, and reservations were being broken down into land allotinents for individual Indians and into "surplus lands" for non-Indian homesteading. In 1934, Congress shifted toward a pohicy of encouraging tribal self-determination. In 1953, Congress abandoned that policy for its opposite: an effort to terminate the sovereignty of tribes and elininate the legal distinctions between Indians and non-Indians. President Nixon formally repudiated that policy in 1970, and today federal Indian policy supports tribal sovcreignty. See generally HANDBOOK OF FEDERAL INDIAN Law 127-206 (R. Strickland ed. 1982) [hereinafter HaNDBoOK OF INDIAN LAW].

8. Indians are inentioned only thrce times in the Constitution. Two places direct that "Indians not taxed" are to be ignored in apportioning the House of Representatives. U.S. CoNST. 
At first glance, the power of Congress in federal Indian law ${ }^{9}$ appears virtually absolute. The Supreme Court has repeatedly said that Congress has plenary power in Indian affairs, ${ }^{10}$ and the Court has never struck down a federal statute directly regulating tribes on the ground that Congress exceeded its authority to govern Indian affairs. ${ }^{11}$ Only in the 1970s did the Court first suggest some general constitutional limit on congressional action, and even then only under a highly deferential standard of review. ${ }^{12}$ When, as sometimes occurs witl aboriginal tribal lands, no treaty or federal statute or agreement specifically recognizes Indian title, Congress may extinguisli the tribe's right of possession without mcurring any legal obligation to pay compensation. ${ }^{13}$ Congress may also unilaterally abrogate a treaty, ${ }^{14}$ even if that resnlts $m$ diminishing or

art. I, $\S 2, \mathrm{cl} .3 ; i d$. amend. XIV, $\S 2$. The only source concerning congressional power authorizes Congress "[to] regulate Commerce with foreign Nations, and among the several States, and with the Indian Tribes." Id. art. I, $\S 8, \mathrm{cl}$. 3; see generally Laurence, The Indian Commerce Clause, 23 ARIz. L. REV. 203 (1981).

9. That is, federal law concerning Native Americans, especially those living in a tribal context. This field is commonly labeled federal "Indian" law, although that does perpetuate Christopher Columbus' geographical misnomer.

10. See, e.g., Cotton Petroleum Corp. v. New Mexico, 109 S. Ct. 1698, 1716 (1989) ("the central function of the Indian Commerce Clause is to provide Congress with plenary power to legislate in the field of Indian affairs"); Rice v. Rehner, 463 U.S. 713, 719 (1983) ("The sovereignty that the Indian tribes retain is of a unique and limited character. It exists only at the sufferance of Congress and is subject to complete defeasance." ") (quoting United States v. Wheeler, 435 U.S. 313, 323 (1978) (emphasis in Rice)). The best treatment of congressional plenary power is Newton, Federal Power over Indians: Its Sources, Scope, and Limitations, 132 U. PA. L. REv. 195 (1984).

11. See Newton, supra note 10 , at $195 \&$ n.1. The boundaries of the assertion in the text should be noted. For example, the Court has struck down a federal statute in part regulating tribal affairs, but not because the statute exceeded congressional authority over tribes. See Muskrat v. United States, 219 U.S. 346 (1911) (statute called upon federal courts to issue advisory opinion). The Court has also found constitutional infirmity in a federal statute regulating the property rights of individual Indians, as opposed to tribal property rights. See Hodel v. Irving, 481 U.S. 704 (1987) (statute providing that small shares of Indian allotment escheat to tribe constituted a taking).

12. The history is well explained in Newton, supra note 10. In a nutshell, the Court at first seemed to hold that congressional power over Indians was a political matter not subjeet to judicial review. See, e.g., Lone Wolf v. Hitchcock, 187 U.S. 553 (1903) (apparently holding that congressional abrogation of an Indian treaty was a political question). The Court has now severely limited this approach. See, e.g., United States v. Sioux Nation of Indians, 448 U.S. 371 (1980) (Lone Wolf's presumption of congressional good faith has hittle to commend it as an enduring principle for cases alleging takings of treaty-protected property); Delaware Tribal Business Comm. v. Weeks, 430 U.S. 73, 84 (1977) ("The statement in Lone Wolf . . that the power of Congress "has always been deemed a political one' . . . has not deterred this Court, particularly in this day, from scrutinizing Indian legislation to determine whether it violates equal proteetion ...."). But the Court continues to consider hines drawn by Congress on the basis of tribal memberslip as political rather than racial classifications, and accordingly it has held that federal regulation does not violate the equal protection component of the due process clause of the fifth ainendment, so long as "the special treatment can be tied rationally to the fulfillment of Congress' unique obligation toward the Indians." Morton v. Mancari, 417 U.S. 535, 555 (1974). It is more than a little ironic that the Americans who were here first have essentially the same eqnal protection guarantees as nonresident aliens. See Matthews v. Diaz, 426 U.S. 67 (1976).

13. See Tee-Hit-Ton Indians v. United States, 348 U.S. 272 (1955).

14. Lone Wolf v. Hitchcock, 187 U.S. 553 (1903). For a thorough discussion and proposed 
disestablishing an Indian reservation. ${ }^{15}$ Governing autliority in Indian country presumptively resides with the federal government and the tribes, ${ }^{16}$ but Congress may freely alter it, assigning the states some important function ${ }^{17}$ or reducimg tribal authority. ${ }^{18}$ Indeed, Congress may even go so far as to terminate the sovereignty of a tribe without its consent. ${ }^{19}$

Where Congress operates with sucl breathtaking authority, ordinary methods of statutory interpretation would suggest that congressional intent, if reasonably identifiable, would control the outcome of most controversies. ${ }^{20}$ After all, even outside federal Indian law the Court sometimes lias said that the "sole task" in statutory interpretation is to discern the congressional intent concerning the issue at hand. ${ }^{21}$ To be sure, sucli comments actually imsconstrue the Court's general interpretive practice, where statutory langnage, broader statutory purposes, statutory evolution, and current values play important roles as well. ${ }^{22}$ Nevertheless, one imight expect that in federal Indian law the Justices would not allow other sources of meaning to trump congressional intent. Simce the Court las placed tribes "at the whim of the sovereign," ${ }^{23}$ with

reform, see Comment, Congressional Abrogation of Indian Treaties: Reevaluation and Reform, 98 YALE L.J. 793 (1989) (authored by Mike Townsend).

15. See infra text accompanying notes 62-77. A clain for just compensation arises if the federal government takes land after a federal treaty, agreement, or statute has "recognized" the Indian title to that land. See Tee-Hit-Ton Indians v. United States, 348 U.S. 272 (1955). In its status as trustee for a tribe, however, Congress has the authority to change the form of Indian property so long as it acts in good faith. See United States v. Sioux Nation of Indians, 448 U.S. 371, 407-09 (1980).

16. See Worcester v. Georgia, 31 U.S. (6 Pet.) 515 (1832). But cf. infra text accompanying notes 179-204 (discussing permitted assertions of state authority in Indian country).

17. See, e.g., infra text accompanying notes $163-78$ (discussing federal statute assigning state courts some criminal and civil jurisdiction in Indian country).

18. See, e.g., infra text accompanying notes 117-39 (discussing the Indian Civil Rights Act of 1968, Pub. L. No. 90-284, tit. II, §§ 201-203, 82 Stat. 77 (1968) (codified at 25 U.S.C. $\$ \S 1301-1303$ (1988)) ("ICRA"), which requires tribes to accord their members certain constitutional protections).

19. See, e.g.. infra text accompanying notes 36-61 (discussing federal statute terminating the federal tribal status of the Menominee Tribe).

20. To test this assumption, this Article adopts a broad definition of congressional intent. See infra notes 31-34 and accompanying tcxt.

21. Commissioner v. Engle, 464 U.S. 206, 214 (1984) ("sole task" of Court in statutory interpretation is to determine congressional intent); see also Public Citizen v. United States Dep't of Justice, 109 S. Ct. 2558, 2566 (1989) (plain statutory language can be overridden by "other evidence of congressional intent"); Blanchard v. Bergeron, 109 S. Ct. 939, 943-44 (1989) (lower court decision controlling because cited approvingly in congressional committee report).

22. See Eskridge \& Frickey, Statutory Interpretation as Practical Reasoning, 42 STAN. L. REv. 321 (1990). Other scholars also recently have debated to what extent-indeed, even whetherlegislative intent should play a role in statutory interpretation. See, e.g., Aleinikoff, Updating Statutory Interpretation, 87 Mich. L. REv. 20 (1988); Eskridge, Dynamic Statutory Interpretation, 135 U. PA. L. REv. 1479 (1987); Farber, Statutory Interpretation and Legislative Supremacy, 78 GEO. L.J. 281 (1989); Farber \& Frickey, Legislative Intent and Public Choice, 74 VA. L. REv. 423 (1988); Popkin, The Collaborative Model of Statutory Interpretation, 61 S. CAL. L. REV. 541 (1988).

23. Newton, At the Whim of the Sovereign: Aboriginal Title Reconsidered, 31 Hastings L.J. 
the sovereign being defined as Congress, one would expect the Court to obey discernible whims.

In the realm of Indian law, however, the Court has articulated some canons of construction that might amehorate some of the harshness of the plenary power doctrine. ${ }^{24}$ These canons originated in a Marshall Court decision interpreting an Indian treaty, ${ }^{25}$ but are sometimes apphed in modern statutory interpretation cases as well. ${ }^{26}$ According to conventional wisdoin, the essential point of the canons is to encourage narrow construction against mvasions of Indian imterests and broad construction favoring Indian rights. ${ }^{27}$ The canons apply, however, only where congressional imtent is unclear; clear congressional intent controls, no matter how harsh the result. ${ }^{28}$

The plenary power doctrine rests on tenuous foundations, as Nell Jessup Newton has shown. ${ }^{29}$ The extent to which the canons actually soften the impact of the doctrine is subject to debate. ${ }^{30}$ Although there is surely more to say about these and related issues, for purposes of this Article I will initially take the law-including the plenary power doctrine

1215, 1215 (1980) (discussing the doctrine of plenary power as applied in Tee-Hit-Ton Indians v. United States, 348 U.S. 272 (1955)).

24. See generally HANDBOOK OF INDIAN LAW, supra note 7, at 221-25; Wilkinson \& Volkman, Judicial Review of Indian Treaty Abrogation: "As Long as Water Flows, or Grass Grows Upon the Earth"-How Long a Time Is That?, 63 CALIF. L. Rev. 601 (1975); Coininent, The Canons of Indian Treaty and Statutory Construction: A Proposal for Codification, 17 U. Mich. J.L. REF, 681 (1984).

25. See Worcester v. Georgia, 31 U.S. (6 Pet.) 515 (1832) (Marsliall, C.J.), discussed at infra text accompanying notes 160-61, 215-17, 408-30.

26. See, e.g., Bryan v. Itasca County, 426 U.S. 373 (1976), discussed at infra text accoinpanying notes 168-78; Menominee Tribe of Indians v. United States, 391 U.S. 404 (1968), discussed at infra text accompanying notes $42-61$.

27. Wilkinson \& Volkman, supra note 24 , at $623-26$, found that sometimes courts will find an invasion of Indian riglits only upon a "clear showing" of legislative intent; other times, such an invasion will not be "liglitly implied"; still otlier cases suggest that such an invasiou may be found only after the court lias engaged in "liberal construction" in favor of Indian rights. The otler formulation tliey identified-that an imvasion of Indian rights should be found only upon express congressional repudiation of the rights in question, $i d$. at 627-30-was later rejeeted in Umited States v. Dion, 476 U.S. 734, 740 (1986). For more background on the canons, see D. GetcheS \& C. WILKINSON, supra note 5 , at 214-17.

28. Dion, 476 U.S. at $739-40$ ("[W]lere the evidence of congressional intent to abrogate is sufficiently compelling, 'the weight of authority indicates that sucl an intent can also be found by a reviewing court from clear and reliable evidence in the legislative listory of a statute.' . . What is essential is clear evidence that Congress actually considered the conflict between its intended action on the one hand and Indian treaty rights on the other, and cliose to resolve that conflict by abrogating the trcaty." (citation omitted)); South Carolina v. Catawba Indian Tribe, 476 U.S. 498, 506 (1986) ("The eanon of construction regarding the resolution of ambiguities in favor of Indians ... does not permit reliance on ambiguities that do not exist; nor does it permit disregard of the clearly expressed intent of Congress.").

29. See Newton, supra note 10 , at $236-38$. For a sliort collection of arguments against the plenary power doctrine, see infra text accompanying notes $340-44$.

30. See Frickey, Scholarship, Pedagogy, and Federal Indian Law, 87 MICH. L. Rev. 1199, 1208-09 (1989). 
and the canons of interpretation - as I find it. Part I examines a variety of important federal Indian law cases imvolving the interpretation of federal statutes and treaties. The cases are used to investigate unexplored questions about the role that congressional intent plays in federal Indian law interpretation. Since Congress seems to be the sole repository of power, any understanding of the field must encompass both a descriptive and a normative evaluation of the role of congressional imtent. Contrary to likely expectations, Part I concludes that congressional intent was only weakly related to the outcomes of these disputes.

This surprising conclusion necessarily leads to a broader assessment of the cases. Part II identifies factors that better explain the outcomes of the cases discussed in Part I. Instead of being tied to the static expectations of the Congress that enacted or ratified the relevant statutes, treaties, or agreements, unany of these factors are dynamic in nature. As Part II demonstrates, these dynamic considerations inform federal Indian law inore than congressional intent alone. Yet, because these factors require both an understanding of the contextual nature of federal Indian law and an appreciation of the appropriate traditions and judicial role in this area, one might question how effectively the contemporary Supreme Court can identify and evaluate them. Indeed, Part II concludes that the cases are largely a collection of ad hoc judicial assessments.

After concludimg in Parts I and II that neither congressional intent nor easily categorized presumptive principles have governed interpretation in federal Indian law, this Article broadens its discussion of the role of theory in this field. The mode of theory now dominant in the field is foundationalist: it seeks to resolve disputes by deductive reasoning from a foundational first principle. Parts I and II seriously undermine foundationahisun's claim as the appropriate approach to federal Indian law. These Parts demonstrate the rejection of a quite plausible foundational theory (imtentionalism in interpretation), and the absence of any foundational alternative. Accordingly, Part III considers ways to construct an antiformalist alternative for federal Indian law scholarship by relying upon recent writings about practical legal reasoning. Part III contends that the problems of federal Indian law are better understood and analyzed through a contextually enriched framework built on the traditions established by Chief Justice Marshall than through the articulation of foundational rules.

Congressional INTENT In Federal Indian LAW

As an introductory matter, it is necessary to define what I mean by 
"congressional intent." The whole notion of legislative intent is subject to the attack that a large, disputatious body like Congress can have no ineaningful, collective intention. Notwithstanding this obvious problem with identifying the "actual" intent of Congress, many lawyers and judges have conventionally conceptualized the role of a judge interpreting a statute as the faithful agent of the enacting legislature. Legislative expectations have salience in a democracy, since statutes embody Congress' authoritative decisions for our polity. Courts usually derive legislative intent from statutory language ${ }^{32}$ and legislative history. ${ }^{33}$ When, as is often the case, these sources reveal no clear legislative intent, courts often engage in a second-best analysis that Judge Posner has aptly called "imaginative reconstruction," which asks what the enacting legislature probably would have done had it anticipated the issue under litigation. ${ }^{34}$

Consistent with these conventions, this Article's use of congressional intent subsumes both specific congressional intent about the issue under hitigation and imaginative reconstruction of probable congressional expectations. The best indices of congressional intent, according to this conventional approach, include statutory language, legislative history, and the general context in which Congress acted.

Obviously some federal Indian law decisions match the apparent intentions of the Congress that enacted the statute or of the Senate that ratified the treaty. ${ }^{35}$ Accordingly, it would be foohsh to suggest that legislative intent is not a serious part of the interpretive equation in many cases. It turns out, however, that legislative intent is not the generally controling factor one might well expect it to be. This Part examines four important areas of federal Indian law, all within Congress' plenary power: treaty abrogation, federal sovereigu immunity, tribal sovereignty, and state regulation in Indian country. In each area, reference to congressional intent does not support the results of the principal cases.

31. For this discussion, I summarize the analysis of legislative intent recently developed in Eskridge \& Frickey, supra note 22, at 325-32.

32. United States v. American Trucking Ass'n, 310 U.S. 534, 543 (1940) ("There is, of course, no more persuasive evidence of the purpose of a statute than the words by which the legislature undertook to give expression to its wishes."); Caminetti v. Umited States, 242 U.S. 470, 490 (1917) ("[W] $]$ hen words are free from doubt they must be taken as the final expression of the legislative intent.").

33. On the use of legislative history in statutory interpretation, see Farber \& Frickey, supra note 22 , at $437-52$.

34. See R. Posner, The Federal Courts: Crisis and Reform 286-93 (1985).

35. A recent, controversial example is Mississippi Band of Choctaw Indians v. Holyfield, 109 S. Ct. 1597 (1989), in which the Court stuck with the language and apparent congressional intent surrounding the Indian Child Welfare Act of 1978, Pub. L. No 95-608, Sec. 2, 92 Stat. 3069 (codified at 25 U.S.C. $\$ \$ 1901-1963$ (1988)), even when that nullified the longstanding adoption of Indian children whose biological parents had voluntarily arranged placement of the children in non-Indian homes. Holyfield is discussed at infra text accompanying notes 294-301. 
Moreover, in circumstances where congressional intent was impossible to reconstruct, the Court has said that it is controlling anyway, and then has found some way of constructimg an intent that happens to accord with the imterpretation reached by the Court.

\section{A. Treaty Abrogation}

The Court's failure to follow the conventional imtentionalist interpretive method is seen in several principal cases involving treaty abrogation. For example, one important decision involved an 1854 treaty providing that the Menominee Tribe of Indians would perpetually hold the Wolf River Reservation in Wisconsin. ${ }^{36} \mathrm{~A}$ century later, in the Menominee Indian Termination Act of 1954, ${ }^{37}$ Congress set out to end federal supervision of the tribe's meinbers and property. Pursuant to the statute, the reservation was disestabhished and the tribe's property was transferred to a corporation organized under state law. ${ }^{38}$ After the property transfer, the statute provided that federal supervision ended, and that "the laws of the several States shall apply to the tribe and its inembers in the same manner as they apply to other citizens or persons within their jurisdiction." 39

Following these events, the Supreme Court of Wisconsin held that the state could regulate hunting and fishing by the Menominees on the forner reservation. ${ }^{40}$ The tribe then sued the United States, contending that the Termination Act, by abohishing the tribe's treaty right to hunt and fish free from state regulation, had taken property for which just compensation was required under the fifth amendment's takings clause. ${ }^{41}$ In Menominee Tribe of Indians v. United States, ${ }^{42}$ the Supreme Court held that the treaty had provided this right, but concluded that no compensation was due because the Tennination Act had not abolished the right. In other words, the Court concluded that the right survived the general abrogation of the treaty, the disestablishment of the reservation, and even the termination of the tribe.

Whatever else might be said about this outcome, it seems inconsistent with evident indications of congressional intent. Recall that the Termination Act said that "the laws of the several States shall apply to 1064.

36. Treaty with Menominee Indians, May 12, 1854, United States-Menominee Tribe, 10 Stat.

37. Pub. L. No. 83-399, 68 Stat. 250 (1954) [hereinafter Termination Act] (codified at 25 U.S.C. $\$ \S 891-902$ (1962)), repealed by Pub. L. No. 93-197, § 3(b), 87 Stat. 770, 770 (1973).

38. For discussion of the details of this conversion of tribal property into corporate assets, see D. GETCHES \& C. WILKINSON, supra note 5, at 148-49.

39. 68 Stat. at 252.

40. State v. Sanapaw, 21 Wis. 2d 377,124 N.W.2d 41 (1963).

41. For an analysis of such claims, see HANDBOOK OF INDIAN LAW, supra note 7, at 467-70.

42. 391 U.S. 404 (1968). 
the tribe and its members in the same manner as they apply to other citizens or persons within their jurisdiction."43 Although the legislative history apparently contained no careful consideration of treaty-based hunting and fishing rights, there was evidence that the congressional intent accorded with the plain meaning of the quoted language.

The Termination Act was just one statute impleinenting a year-old congressional policy that sought "as rapidly as possible, to make the Indians ... subject to the same laws and entitled to the same privileges and responsibilities as are apphicable to other citizens of the Umited States." 44 The Congress that passed the Termination Act had also earlier enacted Public Law No. 280, ${ }^{45}$ which required several states and allowed others to assume some jurisdiction over Indian country. ${ }^{46}$ Public Law 280 contained an exception protecting treaty-based hunting and fishing rights from this delegation of authority to the states. ${ }^{47}$ The later-adopted Termination Act contained no such proviso. Accordingly, a strong argument arises on the face of these statutes that the Congress in question had demonstrated its ability to insulate Indian hunting and fishing rights from state authority. Its failure to do so in the Termination Act reinforces the statute's plain language stating that the Menominee were subject to state regulation.

From a conventional perspective, at least, it is hard to understand Menominee Tribe's analysis of these statutes. The Court contended that the Termination Act and Public Law 280 were in pari materia and that somehow the express exception in Public Law 280 for treaty-based hunting and fishing rights suggested a similar implied exception in the Termination Act. ${ }^{48}$ The Court's opimion did not analyze the contrary argument made above. Moreover, as Justice Stewart pointed out in dissent, the Termination Act provided that all federal statutes regulating tribal Indians no longer applied to the Menominee. ${ }^{49}$ Public Law 280, as such a federal statute, thus seeins of no direct relevance in Menominee Tribe.

43. 68 Stat. at 252 .

44. H.R. Con. Res. 108, 67 Stat. B132 (1953).

45. Act of Aug. 15, 1953, Pub. L. No. 280, 67 Stat. 588 (codified as amended at 18 U.S.C. $\S \S 1161-1162$ (1988), 25 U.S.C. $\S \S 1321-1322$ (1988), 28 U.S.C. $\S 1360$ (1988)).

46. For a definition of "Indian country," see infra note 63.

47. Pub. L. No. 280, § 2(b) (codified as amended at 18 U.S.C. § 1162(b) (1988)) ("Nothing in this section ... shall deprive any Indian or any Indian tribe, band, or community of any right, privilege, or immunity afforded under Federal treaty ... with respeet to hunting, trapping, or fishing or the control, licensing, or regulation thereof.").

48. Menominee Tribe, 391 U.S. at 410-11.

49. Id. at 416 (Stewart, J., dissenting). See Pub. L. No. 83-399, § 10, 68 Stat. 250, 252 (1954) (codified at 25 U.S.C. $\$ 899$ (1962)), repealed by Pub. L. No. 93-197, §3(b), 87 Stat. 770, 770 (1973) ("[A]ll statutes of the United States which affect Indians shall no longer be applicable to the members of the tribe ...."). 
With the plain statutory language of the Termination Act and the emanations from Public Law 280 against them, one would expect the Menominee to lose their liunting and fishing rights absent a clear showing of congressional intent to the contrary. ${ }^{50}$ About all the Court in Menominee Tribe cited to support its position, however, was a comment froin the cliief sponsor, Senator Watkins, that "[t]he bill in no way violates any treaty obhigation witl this tribe."51 The Court considered this quotation to be direct evidence that Congress intended no abrogation of liunting and fishing riglits. ${ }^{52}$ In fact, the cominent undercuts the Court's case for congressional intent.

First, Senator Watkins made the comment after botll Houses of Congress had passed the statute. Sucli subsequent legislative history, particularly coming froin only one legislator, is usually unhelpful (because it is just an off-the-cuff remark) or intentionally misleading (because it ainounts to post loc remaking of legislative intent in a context where it cannot be effectively countered). ${ }^{53}$ Second, and more disturbing, Watkin's statement is false. The Termination Act does not preserve treaty obligations. The Termination Act disestablished the Wolf River Reservation, an area guaranteed by treaty for the Menominee. Third, Watkins' post loc stateinent cannot be reconciled witl his other cominents in the legislative history, which deinonstrate his belief that Indian treaties were contrary to modern policy and of no legal importance. ${ }^{54}$ That the Menominee Tribe opinion fails to recognize the irony in using the Watkins comment is simply one more indication that the Court was

50. Under conventional intentionalist statutory interpretation, a clear congressional intent may trump even seeiningly clear statutory language. See supra note 21 and accompanying text.

51. 100 CONG. REC. 8538 (1954).

52. Menominee Tribe, 391 U.S. at 413 ("Our conclusion is buttressed by the remarks of the legislator chiefly responsible for guiding the Termination Act to enactment . . ...").

53. On the presumptive weakness of such subsequent legislative history, see W. ESKRIDGE \& P. Frickey, Cases and Materials on Legislation: Statutes and the Creation of Public POLICY 752-60 (1988).

54. The principal scholarly study of the termination policy summarized Watkins' attitude as follows:

Watkins had little patience with the concern for Indian treaties. When another subcommittee member suggested that a bill might violate treaty rights, Watkins answered: "It is hike the treaties with Europe. They can be renounced at any time. I would like to comment. ... We have arrived at the point where we do not recognize now within the confines of the United States any foreign nations. You now have become citizens of the one nation. Ordinarily the United States does not enter into treaties . . . between any of its citizens and the Federal Governinent. ... So it is doubtful now that from here on treaties are going to be recognized where the Indians themselves have gone to the point where they have accepted citizenship in the United States and have taken advantage of its opportunities. So that question of treaties, I think, is going to largely disappear."

G. Orfield, A Study of the Termination Policy, reprinted in Subcomm. ON INDIAN Education, Senate Comm. on Labor and Public Welfare, 4 The Education of American INdians: The Organization Question, 91st Cong., 1st Sess. 673, 689-90 (1969) (quoting Termination of Federal Supervision Over Certain Tribes of Indians: Joint Hearings Before the Joint Subcomms. on Indian Affairs, 83d Cong., 2d Sess. 255, 457 (1954) (citations omitted)). 
little concerned about the congressional intent concerning the Termination Act.

Indeed, the Court's decision in Menominee Tribe directly conflicts with the available evidence of congressional intent. The Court acknowledged that one of the bills under congressional consideration had expressly preserved hunting and fishing rights froin state control. ${ }^{55}$ During hearings on the version that was enacted, which lacked an express reservation, counsel for the tribe opposed the bill on the ground that it abrogated those rights. ${ }^{56}$ The Court cited nothing in the legislative history that contradicted the counsel's fears or that supported a congressional intent to preserve such rights. ${ }^{57}$

How could the Court conclude that Congress intended no abrogation of the Menominees' hunting and fishing rights when the plain language of the statute seems to the contrary and the (admittedly sparse) evidence of congressional intent cited by the Court supports that plain meaning? First, the Court invoked a canon of interpretation, namely that " "the intention to abrogate or modify a treaty is not to be lightly imputed to the Congress." "58 Nonetheless, the clear mdications of legislative intent in the statutory language and the legislative history would appear to render the canon mapplicable. Second, the Court doubted that Congress would, "without exphcit statement," subject the federal government to a claim for compensation for the taking of property rights protected by treaty. ${ }^{59}$ But courts do not require an explicit congressional statement concerning just compensation to find a taking. ${ }^{60}$ These transparent conclusions suggest that the Court in Menominee Tribe was

55. Menominee Tribe, 391 U.S. at 408.

56. The majority briefly acknowledged this statement by counsel. Id. Justice Stewart, in dissent, quoted the comment:

"I think it is clear that [the bill] does affect those treaty rights and that those treaties are abrogated. Certainly it abohishes the tribal right to exclusive hunting and fishing privileges, because automatically upon the final terminatiou date, the Menominee Reservation so far as hunting and fishing is concerned, would become subject to the laws of Wisconsin."

Id. at 415 n.5 (Stewart, J., dissenting) (quoting Joint Hearings on S. 2813, H.R. 2828, and H.R. 7135, Before the Subcomms. of Comm. on Interior and Insular Affairs, 83d Cong., 2d Sess. 692, 708 (1954)).

57. The only potentially contrary evideuce that the Court presented was a comment by Senator Watkins in the legislative history of a different termiuation act, dealiug with a different tribe but taken up in the same time frame, that suggested that perhaps the federal government should compensate the tribe for loss of hunting and fishing rights rather than preserve them after termination. See Menominee Tribe, 391 U.S. at 413 n.15 (citing Joint Hearings on S. 2745 and H.R. 7320 Before the Subcomms. of the Comms. on Interior and Insular Affairs, 83d Coug., 2d Sess., Pt. 4, at 254-55 (1954)).

58. Id. at 413 (quoting Pigeon River Co. v. Cox Co., 291 U.S. 138, 160 (1934)).

59. Id.

60. See United States v. Sioux Nation of Indians, 448 U.S. 371 (1980) (finding a taking of Indian property by congressional action which did not acknowledge the possibility of such a fifth amendment claim). 
moved by something other than congressional intent. The Court's opinion provides no hint of what these factors might have been. ${ }^{61}$

Although the Court in Menominee Tribe failed to follow rather evident indications of congressional intent, in another series of cases involving treaty abrogation the Court has purported to obey congressional intent where it did not exist. These decisions concern the scope of "Indian country," a term setting the geographical boundaries important for federal Indian law.

Defining Indian country often beconies a probleın where a statute or agreement has iniplemented the General Allotnient Act of $1887 . .^{62}$ Pursuant to the Act, reservation land was broken down into two primary coniponents: Indian allotnients (small acreages held in trust by the United States for the benefit of the individual Indian "allottee") and "surplus lands" that became available for non-Indian hoinesteading. Since the statutory definition of Indian country nicludes "all land within the limits of any Indian reservation under the jurisdiction of the United States government, notwithstanding the issuance of any patent," 63 the issuance to non-Indians of homestead patents to "surplus" reservation lands did not by itself remove those lands from Indian country. A frequent issue, therefore, is whether the allotnient and surplus land statute or agreenient left the original reservation boundaries intact, diminished the size of the reservation, or disestablished it entirely. Diminishment or disestablishment would, of course, abrogate the treaty that established the reservation.

Purporting to apply a standard that " "congressional determination to terminate [or diminish] be expressed on the face of the Act or be clear from the surrounding circunistances and legislative history," "64 the Court has found reservation diminishment or disestablishment in soine circumstances. ${ }^{65}$ It is even clearer in these cases than in Menominee

61. For a discussion of such factors, see infra text accompanying notes 223-27 \& 285-87.

62. 25 U.S.C. $\$ \S 331-332$ (1988).

63. For purposes of federal criminal law, Indian country is defined as follows:

[T] he term "Indian country", as used in this chapter, means (a) all land within the limits of any Indian reservation under the jurisdiction of the United States government, notwithstanding the issuance of any patent, and, including riglits-of-way running through the reservation, (b) all dependent Indian communities within the borders of the United States whether within the original or subsequently acquired territory thereof, and whether within or without the limits of a state, and (c) all Indian allotments, the Indian titles to which have not been extinguished, including rights-of-way running through the same.

18 U.S.C. $\$ 1151$ (1988). The Supreme Court generally borrows this definition for purposes of civil jurisdiction as well. See DeCoteau v. District County Court, 420 U.S. 425, 427 n.2 (1975) ("While $\S 1151$ is concerned, on its face, only with criminal jurisdiction, the Court has recognized that it generally applies as well to questions of civil jurisdiction.').

64. DeCoteau, 420 U.S. at 444 (quoting Mattz v. Arnett, 412 U.S. 481, 505 (1973)).

65. See Rosebud Sioux Tribe v. Kneip, 430 U.S. 584, 587 (1977) (1904, 1907, and 1910 statutes diminished the size of the Rosebud Sioux Reservation, which had been established by an 1889 
Tribe that the holdings, although couched in legislative intent terms, are based on other factors. Indeed, the Court recently admitted as much.

With uncharacteristic candor for an Indian law opmion, the Court in Solem v. Bartlett ${ }^{66}$ noted that neither the language nor the legislative history of the surplus lands statutes and agreements revealed whether "opened lands retained reservation status or were divested of all Indian interests." ${ }^{67}$ The Court explained that the Congresses involved had no reason to think that reservation boundaries were legally significant. ${ }^{68}$ Following this admission, one might expect continued candor about the difficult judicial role in Indian cases where congressional intent is unavailing, and then some practical resolution of the case. ${ }^{69}$ What one finds in Solem, however, is a disingenuous about-face.

The Court quickly abandoned its realism and returned to the standard amiounced in earlier cases that Congress must "clearly evince an 'intent . . . to cliange . . . boundaries' before dimmishment will be found." 70 The Court noted that in some earlier cases finding diminishment or disestablishment, the surplus land statute contamed "[e]xplicit reference to cession or other language evidencing the present and total surrender of all tribal interests," which according to Solem "strongly suggests that Congress meant to divest from the reservation all unallotted opened lands." the argument is a non sequitur. In one case, for example, disestablishment was found when an agreement provided that the tribes " 'cede, sell, relinquish, and convey to the United States all their claim, right, title and

statute); DeCoteau, 420 U.S. at 427-28 (1889 agreement resulted in the disestablishment of the Lake Traverse Reservation, which had been created by an 1867 treaty).

66. 465 U.S. 463 (1984).

67. Id. at 468 .

68. The Court stated:

When the surplus land Acts were passed, the distinction seemed uninportant. The notion that reservation status of Indian lands might not be coextensive with tribal ownership was unfamiliar at the turn of the century. Indian lands were judicially defined to include only those lands in which the Indians held some form of property interest . . . . Only in 1948 did Congress uncouple reservation status from Indian ownership, and statutorily define Indian country to include lands held in fee by non-Indians within reservation boundaries. . . Another reason why Congress did not concern itself with the effect of surplus land Acts on reservation boundaries was the turn-of-the-century assumption that Indian reservations were a thing of the past. Consistent with the prevailing wisdom, Members of Congress voting on the surplus land Acts believed to a man that within a short timewithin a generation at most-the Indian tribes would enter traditional American society and the reservation system would cease to exist. Given this expectation, Congress naturally failed to be ineticulous in clarifying whether a particular piece of legislation formally sliced a certain parcel of land off one reservation.

Id. (citations omitted). In passing, one might note the irony in labeling the non-Indian community in the United States the "traditional American society."

69. See generally Eskridge \& Frickey, supra note 22 (Supreme Court frequently uses a practical reasoming approach to statutory interpretation).

70. Solem, 465 U.S. at 470 (quoting Kneip, 430 U.S. at 615).

71. Id. 
interest in and to all the unallotted lands." "72 Standing alone, this language only implies a transfer of Indian title to the United States. It says nothing about tribal jurisdiction over the lands.

The Court in Solem continued its analysis of earlier cases by stating that "[w] hen such language of cession is buttressed by an unconditional commitment from Congress to compensate the Indian tribe for its opened land, there is an almost insurmountable presuinption that Congress meant for the tribe's reservation to be diminished."73 Again, although this language is found in earher decisions, the Court's conclusion about congressional intent does not necessarily follow. One would hope that Congress will provide compensation for the taking of treatyprotected land, but if Congress fails to do so just compensation is required by the fifth amendment. ${ }^{74}$ The statutory provision of compensation is consistent with the conclusion that the tribe was merely sellingactually, was being compelled to sell-land to the federal government for a specified anount, not also giving up its potential sovereignty over the land. ${ }^{75}$

Following its imitial candor about the nonexistence of congressional intent and its eventual atteinpt to find it anyhow, the Court in Solem essentially admitted once more that legislative intent cannot adequately explain the results in the cases. The Court acknowledged that in previous decisions it had also considered subsequent factors, such as changed demographics and congressional and executive branch treatinent of the area in question. ${ }^{76}$ This second instance of frankness in Solem provides insight not only into its own holding but more generally into the factors that probably influenced Menominee Tribe. ${ }^{77}$ Nonetheless, on the whole Solem remains another vivid example of just how hard the Court will work to make congressional intent support judicial interpretation in federal Indian law, even in the most inapt circumstances.

\section{B. Federal Sovereign Immunity}

Another area controlled by congressional intent is federal sovereign

72. DeCoteau v. District County Court, 420 U.S. 425, 445 (1975) (quoting Agreement of 1889, art. I, 26 Stat. 1036).

73. Solem, 465 U.S. at $470-71$.

74. See United States v. Sioux Nation of Indians, 448 U.S. 371, 415 (1980).

75. The Court in Solem also recognized that one case went even further in constructing a congressional intent to diminish from even weaker statutory language and almost nonexistent legislative history. Solem, 465 U.S. at 471 (discussing Kneip, 430 U.S. 584). The Court presented these cases matter-of-factly, as precedents somehow to be followed rather than questioned. In this respect, Solem is typical of the Court's federal Indian law opinions, which uncritically take the precedents as law and attempt to identify an answer following from them. See Frickey, supra note 30 , at 1212-14.

76. Solem, 465 U.S. at $471-72$.

77. See infra notes 234-37 and accompanying text. 
immunity. It is elementary that one may not sue the federal government for damages without a congressional waiver of sovereign immunity. ${ }^{78}$ Indeed, such a waiver must be "unequivocally expressed" rather than inferred from unclear statutory langnage. ${ }^{79}$

The General Allotment Act, which we just considered, ${ }^{80}$ contains no evident congressional intent to waive sovereign immunity by creating a right to damages for federal mismanagement of allotted lands. The statute merely states that the Umited States is to "hold the land . . . in trust for the sole use and benefit of the" allottee. ${ }^{81}$ And this is what the Court decided in United States v. Mitchell (Mitchell I), ${ }^{82}$ in which Indians sought damages for alleged federal mismanagement of timber on their allotments. In this case, the Supreine Court disagreed with the Court of Claims' conclusion that the General Allotment Act, by stating that allotments would be held "im trust" by the United States for the allottee, ${ }^{83}$ provided plaintiffs a cause of action for damages. ${ }^{84}$ Justice Marshall's majority opimion held that Congress had not intended to impose fiduciary responsibilities upon the federal government for allotment manageinent, much less to make damages available for the breach of such duties. ${ }^{85}$ Sections 1 and 2 of the Act indicated that the allottee, not the government, was responsible for farming or grazing. ${ }^{86}$ The legislative history indicated that the trust arrangenient was designed primarily to nuake allotments inalienable and free from state taxation. ${ }^{87}$

In dissent, Justice White argned that the statutory words "in trust" should be interpreted as creating a fiduciary relationship, especially since the statute estabished all the elements of a common law trust-a trustee (the Umited States), a beneficiary (the allottee), and a trust corpus (the allotnient). ${ }^{88}$ The problem, of course, is that even if one assumes that by using "in trust" Congress intended the executive branch to have the duties of a private trustee, the statute nowhere expressly waives federal immunity to damages suits for breach of fiduciary duty. Justice White argued rather that hability "follows naturally fron1 the existence of a trust and of fiduciary duties. It is hornbook law that the trustee is

78. See, e.g., United States v. Sherwood, 312 U.S. 584, 586 (1941) (the United States is immune from suit unless it consents to be sued).

79. United States v. King, 395 U.S. 1, 4 (1969).

80. See supra text accompanying notes $62-65$.

81. 25 U.S.C. $\$ 348$ (1988).

82. 445 U.S. 535 (1980).

83. 25 U.S.C. $\S 348$ (1988).

84. Mitchell $I, 445$ U.S. at 539.

85. Id. at $542-46$.

86. Sections 1 and 2 of the General Allotment Act are found at 25 U.S.C. $\$ \S 331-332$ (1988).

87. Mitchell I, 445 U.S. at 543-44.

88. Id. at 547-48 (White, J., dissenting). 
accountable in damages for breaches of trust." ${ }^{89}$ Justice White persuasively contended that monetary damages would serve public policy by compensating the victims and deterring official inalfeasance. ${ }^{90}$ That argument seems unavailing in a sovereigu immunity case, however, where accordimg to longstanding precedent, a right to damages against the United States must be expressly provided by Congress, not judicially constructed froin inore flexible sources of statutory ineaming. ${ }^{91}$

In Mitchell $I$ the Court found good evidence of congressional intent (unlike in Solem) ) $^{92}$ and followed it (unlike in Menominee Tribe). ${ }^{93}$ Yet just three years later, again in an opinion by Justice Marshall, the Court took an about-face. In the second United States v. Mitchell (Mitchell II), ${ }^{94}$ the Court affirmed the judgment of the Court of Claims, which on reinand from Mitchcll $I$ had again assessed damages against the United States for timber imismanagement on allotments. Mitchell II was based on federal tinuber management statutes rather than the General Allotinent Act. ${ }^{95}$ According to the Court in Mitchell II, not only did the Tucker Act ${ }^{96}$ provide the Court of Claims with jurisdiction to hear the claims for damages against the United States, ${ }^{97}$ it also waived the federal government's sovereign immunity. Thus, the Court flatly repudiated its Mitchell $I$ interpretation of the Tucker Act as only a jurisdictional statute, not a waiver of sovereign immunity. ${ }^{98}$

The conclusion reached in Mitchell II concerning the Tucker Act did not resolve the Indian law problein im both Mitchell cases, however. As the Court im Mitchell II admitted, even under its own construction, the Tucker Act simply provides a waiver of sovereign inimunity when one of the sources of law it mentions establishes both a substantive right and a cause of action for damages for violating that right. For the majority in Mitchell II, the question was whether federal timber management

89. Id. at $\mathbf{5 5 0 .}$

90. Id.

91. In cases where "clear statement" rules like the sovereign immunity canon are inapplicable, usual tools of statutory interpretation include the suggestions of statutory language, probable legislative intent, overall statutory purpose, and good policy. See generally Eskridge \& Frickey, supra note 22.

92. See supra text accompanying notes $66-77$.

93. See supra text accompanying notes $42-61$.

94. 463 U.S. 206 (1983).

95. Id. at 209-11.

96. 28 U.S.C. $\S 1491$ (1988).

97. These damages against the United States inay be "founded either upon the Constitution or any act of Congress or any regulation of an executive Department." Id.

98. Mitchell I, 445 U.S. at 538. Because the nature of the Tucker Act is not a question unique to federal Indian law, this conflict between Mitchell $I$ and Mitchell $I I$ need not concern us. 
statutes or regulations " "can fairly be interpreted as mandating compensation by the Federal Government for the damage sustained.',"99 The language of those statutes and regulations, however, is silent about monetary hability for claims of general mismanagement.

For our purposes, let us agree with Mitchell II that a right to damages from the federal government may be found somewhere other than on the face of the statute in question. Under longstanding federal sovereign immumity doctrine, that right could be created ouly upon a showimg of clear congressional intent. Justice Powell, dissenting in Mitchell II, properly summarized federal sovereign immunity law when he said that "whether the U1nited States has created a cause of action turns upon the intent of Congress, not the inclinations of the courts." 100

As Justice Powell noted in Mitchell II, the Court appeared uninterested in the intent of Congress. ${ }^{101}$ The majority opmion cited no legislative history associated with the federal timber management statutes that suggested any congressional intent that damages would be generally available for mismanagement of timber on allotments. Considering the longstanding rule that sovereigu immunity waivers inust be express, the Congresses that enacted these statutes would no doubt be surprised to learn that, many years later, the Court would award dainages for their breach.

Thus, from the standpoint of evident congressional intent, Mitchell $I$ and Mitchell $I I$ are indistinguishable. The statutes involved in both cases do not expressly establish general federal fiduciary responsibilities, do not expressly waive sovereign immumity, and do not provide an express cause of action for dannages. Moreover, the congressional intent surrounding the statutes does not clearly support an imphed cause of action.

99. Mitchell II, 463 U.S. at 217 (quoting United States v. Testan, 424 U.S. 392, 400 (1976) (quoting Eastport S.S. Corp. v. United States, 372 F.2d 1002, 1009 (Ct. Cl. 1967))).

100. Id. at 229 (Powell, J., dissenting) (citations omitted). Indeed, an earlier majority opinion by Justice Marshall concerning the sovereign immunity of tribes also supports the position of Justice Powell in Mitchell II. In Santa Clara Pueblo v. Martinez, 436 U.S. 49 (1978), the Court lield that a tribe could not be sued for injunctive relief for alleged violations of the Indian Civil Rights Act of 1968, 25 U.S.C. $\S \S 1301-1303$ (1988) (ICRA). Justice Marshall noted decisions establishing that tribes possess "the common-law immunity from suit traditionally enjoyed by sovereign powers," that Congress by virtue of its plenary power could waive the immunity, but that any such waiver "'cannot be iniplied but must be unequivocally expressed." Id. at 58 (quoting United States v. Testan, 424 U.S. 392, 399 (1976) (quoting Uuited States v. King, 395 U.S. 1, 4 (1969))). Then, Justice Marshall explained why the language of ICRA did not expose tribes to suit: "Nothing on the face of [ICRA] purports to subject tribes to the jurisdiction of the federal courts in civil actions for injunctive or declaratory relief. ... In the absence liere of any unequivocal expression of contrary legislative intent, we conclude that suits against the tribe under the ICRA are barred by its sovereign inımunity from suit." Id. at 59. Other aspects of Martinez are discussed at infra text accompanying notes 114-39.

101. 463 U.S. at 229 (Powell, J., dissenting). 
Although some might recoil at its outcome, Mitchell $I$ is thus easily compatible with statutory language and original congressional intentions. Mitchell II, im contrast, is similar to Menominee Tribe because the Court reached a result contrary to the probable intent of the enacting Congresses. Unlike in Menominee Tribe, however, the Court in Mitchell II had to maneuver around a "clear statement" requirement involving waivers of sovereigu immumity that seemingly barred the claims of individual Indians. At least im Menominee Tribe, the Court could attempt to draw support from the canons of interpretation applicable to statutes that might invade treaty rights granted to tribes.

Later cases reveal that Mitchell II has not revolutionized federal sovereign immumty law in general ${ }^{102}$ or in Indian cases in particular. ${ }^{103}$ Indeed, simce Mitchell II the Court has shown enthusiasm for the policies associated with sovereign immunity. The Court has extended tort immunity to federal military contractors despite the absence of any express statutory protection for them, ${ }^{104}$ and has continued to adhere to the much-criticized $^{105}$ Feres doctrine, which bars suit by military servicemembers for service-related mjuries due to the negligence of a fellow servicemember or federal civilian employee. ${ }^{106}$

On the Feres issue, the Court has explained that barring the claims of servicemembers is supportable because their relationship with the government is umiquely federal in nature, the government provides many statutory disability and death benefits to them anyway, and theirs "are the 'type[s] of claims that, if generally permitted, would involve the judiciary in sensitive military affairs at the expense of military discipline and effectiveness.' "107 The federal-Indian relationship is somewhat analogous: it is umquely federal, the federal government provides tribes and their members with many benefits, and judicial inquiry into federal management of Indian assets could inhibit admmistrative effectiveness.

102. See, e.g., Library of Congress v. Shaw, 478 U.S. 310,318 (1986) ("In analyzing whether Congress has waived the immunity of the United States, we must construe waivers strictly in favor of the sovereign, and not enlarge the waiver "beyond what the language requires." (quoting Ruckelshaus v. Sierra Club, 463 U.S. 680, 685-86 (1983) (quoting Eastern Transp. Co. v. United States, 272 U.S. 675, $686(1927))$ ).

103. In a sovereign immunity case involving Indians following Mitchell $I$ and Mitchell $I I$, the Court quoted Mitchell $I$ for the proposition that "even for Indian plaintiffs, "[a] waiver of sovereign immunity cannot be lightly implied but must be unequivocally expressed.'" United States v. Mottaz, 476 U.S. 834, 851 (1986) (quoting Mitchell I, 445 U.S. at 538 (quoting United States v. King, 395 U.S. 1, 4 (1969))).

104. See Boyle v. Umited Technologies Corp., 487 U.S. 500 (1988).

105. See, e.g., Note, United States v. Johnson: Expansion of the Feres Doctrine to Include Servicemembers' FTCA Suits Against Civilian Government Employees, 42 VAND. L. REV. 233 (1989), and sources cited id. at 234 n.9.

106. See United States v. Johnson, 481 U.S. 681 (1987).

107. Id. at 690 (emphasis omitted) (quoting United States v. Shearer, 473 U.S. 52,59 (1985)). 
When one adds two other factors-the longstanding congressional plenary power doctrine and the likelihood that Indians have more compensable grievances against the federal government than any other group ${ }^{108}$ _one might well expect the Supreme Court to be particularly penurious im its approach to sovereign immunity im Indian cases. ${ }^{109}$ For all these reasons, whatever led to the result in Mitchell $I I$ seems both reniarkable and contrary to probable congressional expectations. ${ }^{110}$

\section{Tribal Sovereignty}

The extent of tribal sovereignty is yet another issue on which one would expect congressional imtent to play a significant role. The inherent tribal sovereignty that existed before colonization can be diminished im one of three ways: by treaty or agreement, by federal statute, or by a judicial holding that some tribal authority is inconsistent with the tribe's "dependent status."111 In the first method of diminishing tribal sovereignty - by treaty - the Indian law canons allow some deviation froin the

108. Indeed, in Mitchell II the Court noted that damages in that case might amount to $\$ 100$ million. 463 U.S. at 211 n.7.

109. On at least one occasion the Court seemingly admitted that the sheer magnitude of federal money that Indians might recover suggested that their claims should not be legally cognizable. See Tee-Hit-Ton Indians v. United States, 348 U.S. 272, 283 n.17 (1955).

110. In the Mitchell cases, there were effectively three groups of Justices: those who would make money damages available in both cases (Justices Brennan, White, and Stevens); those who would allow damages in neither case (Justices Powell and Rehnquist); and those who would allow damages only in the second case (Justices Marshall and Blackmun). The majority in Mitchell II consisted of the Brennan group plus Justices Marshall, Blackmun, and Chief Justice Burger, who had not participated in Mitchell I. Justice O'Connor joined the dissent in Mitchell II, presumably carrying on the preference of her predecessor, Justice Stewart, who had been in the majority in Mitchell $I$.

It might seem impossible to reconcile the swing votes of the two Justices (Marshall and Blackmun) who were essential in constituting the majorities in Mitchell $I$ and Mitchell II. As with Menominee Tribe and Solem, however, there may be factors other than congressional intent that shaped their decisions and thus the outcomes in both of the Mitchell cases. See infra text accompanying notes $238-42$.

111. In United States v. Wheeler, 435 U.S. 313 (1978), the Court summarized its approach to the sovereignty of Indian tribes. Before colonization, tribes were "self-governing sovereign political communities" with "the inherent power to prescribe laws for their members and to punish infractions of those laws," but since then,

[t] heir incorporation within the territory of the United States, and their acceptance of its protection, necessarily divested them of some aspects of the sovereignty which they had previously exercised. By specific treaty provision they yielded up other sovereign powers; by statute, in the exercise of its plenary control, Congress has removed still others.

... The sovereignty that the Indian tribes retain is of a urique and limited character. It exists only at the sufferance of Congress and is subject to complete defeasance. But until Congress acts, the tribes retain their existing sovereign powers. In sum, Indian tribes still possess those aspects of sovereignty not withdrawn by treaty or statute, or by implication as a necessary result of their dependent status.

Id. at 322-23 (citations omitted).

This language is loaded with ironic and doubtful assertions. For example, who incorporated the tribes into the United States? In what ways did the tribes accept protection from the United States? Where did Congress get its plenary power over tribes? (One looks in vain in the Constitution for any 
unilateral intent of the federal officials who negotiated the treaty or the Senate that ratified it, primarily because treaties are ostensibly consensual. ${ }^{112}$ In cases involving the second or third inethods of divesting tribal sovereignty, however, one would expect that congressional intent is a key, if not controlling, factor. Under the second method of divestinentby federal statute-conventional intentionalist interpretation would accord congressional intent great weight, particularly in light of the plenary power doctrine. Under the third method-by judicial line drawing based on the tribes' dependent status-the plenary power doctrine likewise would seemingly counsel strong judicial deference to any perceived congressional perceptions. This Section investigates this expectation for judicial deference, first in cases involving tribal regulation of nembers, and then in cases concerning tribal regnlation of nonmenbers. ${ }^{113}$

\section{Tribal Regulation of Members}

Santa Clara Pueblo v. Martinez ${ }^{114}$ is the principal modern case concerning congressional divestment of tribal sovereignty over its members. To understand Martinez, one must first note that tribal sovereignty is inherent and "pre-constitutional": it flows neither from the Constitution nor from any delegation of federal authority. ${ }^{115}$ Accordingly, the Constitution does not apply to exercises of a tribal government's inherent

specific grant of such power. See supra note 8.) Nonetheless, the dictum fairly summarizes the Court's approach to contemporary tribal sovereignty. Since for the moment we should be content to take the law as we find it, we can accept the Court's summary without pausing to critique its normative attractiveness.

112. In such situations, one can imvoke a variety of contract interpretation principles to help the Indian cause: the treaty should, as a contract of adhesion, be narrowly interpreted against its drafter (the federal government); because the treaty was written (and perhaps also negotiated) in a language foreign to the tribe, its provisions should be read as the Indians probably understood them, not as what a literal reading of the English language might suggest; because the federal government is a trustee for the tribe, the treaty is similar to a trust agreement that should be broadly interpreted to protect the beneficiary; and so on.

That the canons of Indian treaty interpretation grow out of such analogies is well argued in Wilkinson \& Volkman, supra note 24, at 608-20. One problem with this line of argument, however, is that it assumes that all Indian treaties are essentially fungible. The historical record indicates, to the contrary, that many early treaties were probably like bilateral contracts; the tribes were bargaining from situations of strength. In contrast, many later treaties and agreements were imposed on tribes unilaterally, often when their members were essentially prisoners of war, and their terms were often unilaterally changed anyway before ratification by the Senate. Wilkinson \& Volkman, supra note 24 , at $608-09$, briefly note this historical trend, but fail to consider whether it undermines the method of consistently borrowing contract interpretation canons.

113. Until recently it was unclear whether the relevant group over which a tribe has extensive sovereignty is its "members" or all "Indians." The Supreme Court resolved the issue in Duro v. Reina, 110 S. Ct. 2053 (1990), holding that only tribal members are subject to any expansive conception of inherent tribal sovereignty.

114. 436 U.S. 49 (1978).

115. See supra note 111. 
sovereignty. ${ }^{116}$ Congress effectively changed this arrangeinent in the Indian Civil Rights Act of 1968 (ICRA), ${ }^{117}$ which commands tribal governinents to adhere to requireinents paralleling soine of the Constitution's protections of individual rights.

Martinez involved the degree to which ICRA diminished inherent tribal sovereignty. Martinez was a woman who belonged to the Santa Clara Pueblo and had married a Navajo inan by whoin she had several children. Her tribe used a patrilineal ineinbership rule for children born of marriages between a tribal member and a nonmeinber: children were eligible for tribal membership only if the father was a meinber. After failing to convince the tribe to change the membership rule, Martinez and one of her children challenged the rule as inconsistent with ICRA's requirement that tribes may not deny equal protection. ${ }^{118}$

A nearly unanimous Court in Martinez held that the federal courts could provide no rehef even if the tribal rule violated ICRA. ${ }^{119}$ Justice Marshall's opinion reaclied this remarkable outcome by holding that the only federal judicial remedy for violations of ICRA was that which the statute expressly provided-habeas corpus. ${ }^{120}$ Thus, injunctive relief in federal court was unavailable to reinedy tribal violations of ICRA.

The general question in Martinez-whether federal courts should iniply civil causes of action under federal statutes that create rights but do not expressly provide corresponding civil reinedies-has sliarply divided the Court. ${ }^{121}$ Most recently, the Court lias said that the question turns on congressional intent. ${ }^{122}$ Martinez purported to follow a similar approacl by relying largely upon the statutory language and legislative history.

The most obvious argument is simply that habeas corpus is the only rehef mentioned in the language of the statute. Supporting this argument is the longstanding canon of statutory interpretation that the "inclusion of one thing indicates the exclusion of the other" (referred to in shortland as expressio unius). ${ }^{123}$ The maxim is a weak one, however. It

116. See Talton v. Mayes, 163 U.S. 376 (1896).

117. Pub. L. No. $90-284$, tit. II, $\S \S 201-203$, 82 Stat. 77 (1968) (codified at 25 U.S.C. $\S \S 1301-$ 1303 (1988)).

118. Martinez, 436 U.S. at 53-54. The statute provides that "[n]o Indian tribe in exercising powers of self-government shall ... deny to any person within its jurisdiction the equal protection of the laws." 25 U.S.C. $\$ 1302(8)$ (1988).

119. Martinez, 436 U.S. at 72. Justice Rehnquist concurred in the portions of Martinez relevant to our discussion, Justice Blackmun did not participate, and only Justice White dissented.

120. Id. at 70; see 25 U.S.C. $\$ 1303$ (1988) (habeas corpus statute).

121. For an historical overview, see Foy, Some Reflections on Legislation, Adjudication, and Implied Private Actions in the State and Federal Courts, 71 CORNELL L. REV. 501 (1986).

122. See Karahalios v. National Fed'n of Fed. Employees, Local 1263, 109 S. Ct. 1282, 1286 (1989).

123. W. ESKRIDGE \& P. FRICKEY, supra note 53, at 641 . 
assumes that the legislature carefully drafts statutes, is aware of all their details, and intends the interpreter to draw the negative inference posited by the canon. It does not recognize that the legislature inay only want to guarantee that the inatter expressly inentioned becoines positive law. ${ }^{124}$ The lower courts in Martinez did not follow the expressio unius approach, and the statutory language undermines this tack.

The language of the habeas corpus provision suggests that Congress inerely intended to guarantee the availability of habeas corpus relief, not to limit the availability of other federal remedies. ${ }^{125}$ Moreover, many of the civil rights granted by the statute-such as the free exercise of religion, freedoin of speech, equal protection, and due process ${ }^{126}$ - cannot be ineaningfully protected without the availability of injunctive relief. ${ }^{127}$ The statute also forbids the taking of property without just compensation, ${ }^{128}$ for which injunctive relief or dainages would be the appropriate reinedy.

As a second supporting argument, the Court in Martinez suggested that the legislative history of ICRA revealed that Congress had carefully crafted the habeas corpus provision as the only federal relief to avoid undue interference with tribal sovereiguty. ${ }^{129}$ But the Court did not cite any legislative history stating that habeas corpus was the only federal reinedy. To be sure, the legislative history primarily focused on protecting criminal defendants in tribal courts. Congress did not wish to abolish tribal courts, and it rejected the remedy of federal appellate review of tribal court criminal convictions because tribal courts did not ordinarily produce a sufficient record for review by appeal. A proposal for a de novo trial in federal district court eventually became the habeas corpus guarantee. The Senate committee print explaining ICRA listed habeas corpus along with the "constitutional" rights granted by the statute, which suggests that the committee viewed habeas corpus as a right, not

124. Id.

125. 25 U.S.C. $\S 1303$ (1988) ("The privilege of the writ of habeas corpus shall be available to any person, in a court of the United States, to test the legality of his detention by order of an Indian tribe.").

126. 25 U.S.C. $\S 1302(1)$, (8) (1988).

127. Technically speaking, Martinez held only that the federal courthouse door is barred to injunctive actions under ICRA. Martinez assumed that tribal courts "are available to vindicate rights created by the ICRA." 436 U.S. at 65 . Relegating these cases to the tribal courts may be good policy, but it is liard to square with conventional intentionalist interpretation. It is unlikely that the Congress viewed tribal courts as a sufficient source of protection of the rights created by ICRA. For a discussion, see Martinez, 436 U.S. at 80-83 (White, J., dissenting). See generally Comment, The Indian Bill of Rights and the Constitutional Status of Tribal Government, 82 HARV. L. REV. 1343, 1355-60 (1969) (summarizing legislative history that found tribal courts to "resemble justice of the peace courts" that, in some tribes, are not independent from other tribal governmental institutions).

128. 25 U.S.C. $\$ 1302(5)$ (1988).

129. Martinez, 436 U.S. at $62-70$. 
just a remedy. ${ }^{130}$ Furthermore, the legislative history reflects concerns about tribal abuses of Indians in situations which could not be remedied by release froin detention. ${ }^{131}$ This background suggests that Congress simply intended to ensure the availability of habeas corpus, not make it the exclusive remedy.

This conclusion is bolstered by another aspect of the statute. The language and legislative history of ICRA reveal a concern with protecting both Indians and non-Indians from potential abuses by tribal governments. ${ }^{132}$ Indeed, the year after ICRA became law a bill was introduced, but not passed, that wonld have amended ICRA to protect only Indians, indicating a concern that ICRA as adopted covered non-Indians. ${ }^{133}$ The Court in Martinez should have realized that habeas corpus was not relevant to non-Indians because shortly before it decided Martinez it had held that tribes have no criminal jurisdiction over non-Indians. ${ }^{134}$

The Court could have addressed the concerns expressed in the legislative history differently by following the approach to ICRA taken by several lower courts prior to Martinez. These courts had assumed that federal imjunctive rehef was available for violations of ICRA, but concluded that federal intrusiveness should be limited in two ways. First, the protections of ICRA did not have to be interpreted to mirror the Bill of Rights, but rather could be modified to accord with the unique tribal context. ${ }^{135}$ Second, the federal courts could have reasonably limited ICRA by imposing procedural requirenents such as exhaustion of tribal remedies $^{136}$ and by declining to provide injunctive rehef except where

130. See, eg., Comment, supra note 127 , at 1371.

131. See Burnett, An Historical Analysis of the 1968 'Indian Civil Rights' Act, 9 HaRv. J. ON LEGIS. 557, 581-82 (1972) (tribal council interference with religious practices of some Indians).

132. All the guarantees of ICRA, including the habeas corpus provision, are worded generally as rights of the "people" or "any person." 25 U.S.C. $\S \S 1302-1303$ (1988). For a discussion, with citations to some of the legislative history, of some ways in which the statute might protect noninembers from tribal action, see Comment, supra note 127, at 1360-68. See also Burnett, supra note 131, at $602 \mathrm{n} .239$ (proposed version of ICRA was redrafted prior to enactment to guarantee equal protection to any person withm the tribe's jurisdiction rather than limiting it to members of the tribe, as had been recommended by Interior Departinent).

133. See Burnett, supra note 131, at 614-15.

134. Oliphant v. Suquamish Indian Tribe, 435 U.S. 191 (1978), which so held, was decided about two months before Martinez. Oliphant is discussed at infra text accompanying notes 140-57.

135. See Wounded Head v. Tribal Council of Oglala Sioux Tribe, 507 F.2d 1079 (8th Cir. 1975) (holding that tribe voting age requirement does not violate ICRA equal protection provision simce a contrary ruling would be equivalent to forcing an alien culture on tribe); Jacobson v. Forest County Potawotomi Community, 389 F. Supp. 994 (E.D. Wis. 1974) (tribe's exclusion of women from holding office in tribal council and denial of suffrage to those under 21 years of age lield not to violate ICRA since tribes need not have republican form of government).

136. See McCurdy v. Steele, 506 F.2d 653 (10th Cir. 1974) (holding that tribe had to address issue of electoral procedure before federal court could intervene); O'Neal v. Cheyenne River Sioux Tribe, 482 F.2d 1140 (8tlı Cir. 1973) (individual plaintiff had to exhaust tribal remedies before bringing suit in federal court under ICRA). The Supreme Court las taken a similar strategy in 
necessary to correct inanifest injustice. ${ }^{137}$ These approaches would have been superior to that taken in Martinez to address the dual concerns expressed in the legislative history - the need for a federal check on tribal government without drastically weakening tribal sovereignty.

As the third justification for its restrictive reading of ICRA, the Court in Martinez invoked a canon that requires a clear indication of legislative intent before tribal sovereignty can be undermined. ${ }^{138}$ But ICRA was designed to undermine tribal sovereignty, and nothing in the legislative history provides a clear indication that habeas corpus was the only federal remedy available under the Act. By limiting federal reinedial relief in this way, the Court essentially prevented the statute from providing any ineaningful protection in non-tribal forums for many of the riglits it purportedly guarantees. It appears that the Court should have required inore than a canon of clear stateinent to overcome these arguments against its holding.

As with the otlier cases we have surveyed, Martinez seems inconsistent with congressional intent, even when filtered through the Indian law canons. It reseinbles the other cases in another crucial respect: it is supportable on other grounds. ${ }^{139}$

\section{Tribal Regulation of Nonmembers}

The principal case involving tribal attempts to regulate a nonmember, Oliphant v. Suquamish Indian Tribe, ${ }^{140}$ arose where no federal statute autliorized or forbade the tribal regulation, ${ }^{141}$ and thus turned on whether the exercise of sovereignty was consistent with the tribe's

recent cases in which non-Indian civil defendants in tribal court seek federal injunctive relief against the tribal court proceedings. See infra text accompanying notes 444-54.

137. For example, it would have been easy to hold, by analogy to Younger v. Harris, 401 U.S. 37 (1971), that federal courts may not enjoin a criminal prosecution in tribal court absent compelling circumstances like harassment or prosecutorial bad faith. More generally, the federal courts could have strictly enforced the old naxim of equity that one must prove irreparable injury before an injunction may be obtained.

138. The Court wrote that "[a]lthough Congress clearly has power to authorize civil actions against tribal officers, and has done so with respect to habeas corpus relief ..., a proper respect both for tribal sovereignty itself and for the pleuary authority of Congress in this area cautions that we tread hightly in the absence of clear indications of legislative intent." Martinez, 436 U.S. at 60 . The quote comes from the beginning of the Court's discussion, as a background norm. Id. at 59.60. The Court returned to the same theme at the end of the opinion. Id. at 72.

139. See infra text accompanying notes $243-47$ \& 288-93.

140. 435 U.S. 191 (1978). Strictly speaking, Oliphant concerned tribal regulation of a nonIndian. The Court's recent decision in Duro v. Reina, 110 S. Ct. 2053 (1990), extends the holding of Oliphant to govern tribal regulation of "nonmember Indians," that is, Indians who are not members of the tribe seeking to regulate them.

141. Oliphant, 435 U.S. at 195 n.6; cf. United States v. Mazurie, 419 U.S. 544 (1975) (upholding federal statute delegating authority to Indian tribe to regulate liquor sales by all persons, including nonmembers, in Indian country). 
"dependent status." 142 Although one might expect that any indication of congressional intent regarding the extent of tribal authority would greatly influence the judicial outcoine, congressional expectations did not support the decision, and later cases have largely abandoned any reliance on congressional intent.

Oliphant held that a tribe may not assert criminal jurisdiction over a non-Indian who commits a crime on the reservation even if the perpetrator hives there. ${ }^{143}$ Justice Rehnquist's opinion gave "considerable weight" to "the commonly shared presumption of Congress, the Executive Branch, and lower federal courts that tribal courts do not have the power to try non-Indians." 144 Almost all the evidence that Justice Rehnquist marshalled to support his conclusion about congressional intent, however, was indirect and largely imphicit. ${ }^{145}$ For exainple, he

142. Oliphant, 435 U.S. at 196. For a discussion of the sovereignty of Indian tribes, see supra note 111 .

143. Oliphant, 435 U.S. at 195.

144. Id. at 206.

145. For present purposes, we need only note that Justice Rehnquist cited weak evidence to support his conclusion about the expectations of the executive branch and the judiciary. For the judicial branch, Justice Rehnquist cited only one lower court decision holding that a tribal court could not try non-Indians. Id. at 199-200 (discussing Ex parte Kenyon, 14 F. Cas. 353 (W.D. Ark. 1878) (No. 7720)). In addition, Justice Rehnquist quoted the most respected source on federal Indian law:

According to Felix Cohen's Handbook on Federal Indian Law 148 (U.S. Dept. of the Interior 1941) 'attempts of tribes to exercise jurisdiction over non-Indians . . . have been generally condemned by the federal courts since the end of the treaty-making period [i.e., since 1871], and the writ of habeas corpus has been used to discharge white defendants from tribal custody.'

Id. at 199 n.9. But Cohen's book cited only Kenyon to support this statement.

As to the executive branch, Justice Rehnquist noted that the Solicitor of the Department of the Interior, in a 1970 opinion, reaffirmed Kenyon, id. at 200-01, but then acknowledged in a footnote that the Solicitor had withdrawn this opinion in 1974. Id. at $201 \mathrm{n} .11$. Justice Rehnquist also noted that the Attorney General had issued two opinions in the nineteenth century stating that the Choctaw Tribe liad no authority to prosecute non-Indians. Id. at 198-99 (citing 2 Op. Att'y Gen. 693 (1834); 7 Op. Att'y Gen. 174 (1855)).

The 1830 treaty between the Choctaw and the Umited States, however, is not capable of generalization to other tribes and other treaties. First, the treaty contained language indicating that the tribe wanted congressional autliority to prosecute non-Indians. Id. at 197. Apparently no other Indian treaty had this kind of language. Barsl \& Henderson, The Betrayal: Oliphant v. Suquamisl Indian Tribe and the Hunting of the Snark, 63 MinN. L. REv. 609, 617 (1979).

Second, the treaty was negotiated under unusual circumstances: the Choctaw and seven otler eastern tribes were deeded western lands in fee simple in exchange for their aboriginal lands. Id. "Since these tribes lield their territory as landowners rather than as sovereigns, it is not surprising that their treaties included provisions delegating to thein limited powers of self-government." Id. at 617-18. The ordinary Indian treaty, in contrast, delegates no power to a tribe; it assumes that tribes retain all sovereignty not expressly ceded away. See Winters v. United States, 207 U.S. 564 (1908) (state cannot appropriate water rights reserved by tribe); United States v. Winans, 198 U.S. 371, 381 (1905) (Indian treaties are grants of rights from Indians to federal government, and thus all rights, including fishing riglits, not expressly ceded are retained by the tribes).

Justice Rehnquist also noted that federal regulation limits certain courts in Indian country-the so-called "CFR courts," which are descendants of the Courts of Indian Offenses establislied by Congress in 1888-to criminal jurisdiction over Indians within the reservation. Oliphant, 435 U.S. 
noted that longstanding federal statutes and treaties provide that nonIndians who commit crimes in Indian country are subject to federal or state prosecution. ${ }^{146}$ There is no indication, however, that these provisions were designed to provide exclusive state or federal jurisdiction, as opposed to concurrent jurisdiction with tribal courts.

Even Justice Rehnquist's direct evidence of congressional intent was weak. He first cited a bill introduced in 1834 but never enacted, which would have forbidden tribes in a proposed western Indian territory from exercising criminal jurisdiction over non-Indians traveling though the area. ${ }^{147}$ As he noted, however, even this bill did not purport to immunize non-Indians froin tribal criminal prosecution if they settled in Indian territory. ${ }^{148}$

He also cited a 1960 Senate committee report concerning a statute making it a federal crime to hunt or fish on Indian land without permission. ${ }^{149}$ This report assuined that a federal sanction was needed because tribal law could not be enforced against non-Indians. But the views expressed are, at best, simply those of the legislators on one committee of one house of Congress, and there is no indication that the legislators were well-informed about, or gave much thought to, the problein. It is purely speculative whether these legislators would have coine to the same conclusion if they could have foreseen tribal courts that largely operate according to Anglo-American legal procedures, have only limited sentencing authority, and are subject to habeas corpus review by federal courts. Such was the case for at least some tribal courts by the time Oliphant was decided, a decade after the passage of the Indian Civil Rights Act of 1968.

Indeed, Justice Rehnquist inade short shrift of contemporaneous congressional expectations surrounding the 1968 enactinent of ICRA that were contrary to his Oliphant holding. As discussed earlier, ${ }^{150}$ ICRA requires tribal governments, including tribal courts, to respect certain civil rights. As proposed, the statute would have accorded these

at 196 n.7. There is no such federal statutory or administrative limitation, however, for tribal courts functioning under the tribe's inherent powers, such as the one at issue in Oliphant. Id. at 195-96. Thus, if one considers all federal statutory and administrative rules in pari materia, so that they could be read as one body of law, the express limitation for CFR courts suggests no federal intention to limit the jurisdiction of other tribal courts. This argument, another version of expressio unius, is subject to the strong criticism that neither Congress nor the executive branch can be expected to know all sources of Indian law, much less enact law that renders all of it harmonious. See supra text accompanying notes 123-24. Nonetheless, it does further weaken Justice Rehnquist's arguments about the shared conclusions of the judicial and executive branch.

146. Oliphant, 435 U.S. at 197 n.8, 201-03.

147. Id. at 201-03.

148. Id. at 202 n.13.

149. Id. at 204, 206 (citing S. REP. No. 1686, 86th Cong., 2d Sess. 2-3 (1960)). The statute in question is codified at 18 U.S.C. $\$ 1165$ (1988).

150. See supra text accompanying notes $115-17$. 
rights to "American Indians"; as adopted, it extended its guarantees to "any person." 151 The legislative history of ICRA indicates that Congress intended to protect Indians and non-Indians alike from abuses by tribal governments. ${ }^{152}$ The relevant Senate subcommittee explained that the change in language to "any person" was designed to protect " 'all persons who may be subject to the jurisdiction of tribal governments, whether Indians or non-Indians." "153

Justice Rehnquist responded that the change in ICRA was merely intended to "extend the Act's guarantees to non-Indians if and where they come under a tribe's criminal or civil jurisdiction by either treaty provision or Act of Congress." 154 But this conclusion simply begs the question. Moreover, notwithstanding Oliphant, federal law sometimes allows tribes to assert civil jurisdiction over non-Indians without specific congressional authorization. ${ }^{155}$ Fmally, Justice Rehnquist paid little heed to the American Indian Policy Review Commission's report issued only a year prior to Oliphant. The Commission, which was established by Congress and made up im part by members of Congress, had concluded that "[ $t]$ here is an established legal basis for tribes to exercise jurisdiction over non-Indians."156

Later in Oliphant, Justice Rehnquist shifted the focus away from the expectations of the federal branches (and from the provisions of the relevant treaties with the tribe) and justified the holding in the case solely on other grounds. ${ }^{157}$ His analysis of congressional expectations is, therefore, not only tenuous but largely irrelevant.

151. Oliphant, 435 U.S. at 195 n.6.

152. See supra text accompanying notes $132-33$.

153. Oliphant, 435 U.S. at 195 n.6 (quoting Subcomm. ON CONSTITUTIONAL RighTS OF THE Senate Comm. on the Judiciary, 89Th CONG., 2D Sess. 10, Summary Report on the CONSTITUTIONAL RIGHTS OF AMERICAN INDIANS (1966)).

154. Id. at 196 n.6.

155. The Supreine Court has upheld tribal authority to tax non-Indians. See Kerr-McGee Corp. v. Navajo Tribe of Indians, 471 U.S. 195 (1985) (upholding tribal ordinances imposing taxes on the value of leasehold interests in tribal lands even absent approval by Secretary of the Interior); Merrion v. Jicarilla Apache Tribe, 455 U.S. 130 (1982) (upholding tribal right to tax oil and gas production on Indian land). The Court has also implicitly authorized tribal courts to assume jurisdiction over civil suits brought by inembers against nonmembers. See infra text accoinpanying notes 444-56. The Court has also suggested that tribes may sometimes regulate land use on fee land in Indian country owned by nonmembers. See infra text accompanying notes 308-21.

156. Oliphant, 435 U.S. at 205 n.15 (quoting 1 FINAL REPORT OF THE AMERICAN INDIAN Policy REviEw COMM'N 114, 117, 152-54 (1977)). Justice Rehnquist stated that the report relied only upon the lower court decision in Oliphant and a companion case, and did not deny that until recently the three federal branches "were in apparent agreement that Indian tribes do not have jurisdiction over non-Indians." Id.

157. In a critical passage, Justice Rehnquist stated that "an examination of our earlier precedents satisfies us that, even ignoring treaty provisions and congressional policy, Indians do not have criminal jurisdiction over non-Indians absent affirmative delegation of such power by Congress." Id. at 208. For a discussion of the factors that probably controlled the outcome in Oliphant, see infra text accompanying notes 248-54 \& 304-07. 
In later cases dealing with the tribe's inherent sovereignty to regulate nonmembers, the Court has made no sustained attempt to justify the outcomes on the basis of congressional expectations. ${ }^{158}$ Perhaps the most meaningful role Congress has played in these cases has been to give the Court a way to defiect responsibility. As Justice Rehnquist stated in Oliphant, rejecting the policy argument that the prevalence of nonIndian crime in Indian country should justify tribal criminal jurisdiction over non-Indians, "these are considerations for Congress to weigh in deciding whether Indian tribes should finally be authorized to try nonIndians." 159

\section{State Regulation in Indian Country}

In 1832, in Worcester v. Georgia, ${ }^{160}$ Chief Justice Marshall described an Indian reservation as "a distinct community occupying its own territory, with boundaries accurately described, in which the laws of [the state] can have no force." 161 Nonetheless, Congress, because of its plenary power, may rearrange sovereignty in Indian country by delegating regulatory power to the state. ${ }^{162}$ One would expect the meaning of such delegations to turn in large part upon congressional intent. Part One of this Section reviews the principal case deahing with delegation of authority to the states.

States have also attempted to govern activity in Indian country in the absence of any overt congressional authorization. The Court has backed away from Worcester's flat rule against state authority and has rather adjudicated the appropriateness of such state intrusions into

158. In truth, the cases are a motley lot. The primary case in which the Court upheld tribal power to tax nonmembers is premised not on the basis that Congress has authorized the tax, but primarily on the notion that the power to tax is an essential attribute of sovereignty. See Merrion v. Jicarilla Apache Tribe, 455 U.S. 130 (1982). A second tax case, Kerr-McGee Corp. v. Navajo Tribe of Indians, 471 U.S. 195 (1985), is written in a more intentionalist vein. The cases involving tribal court jurisdiction over civil actions brought by members against nonmembers, see infra text accompanying notes 444-56, were not decided primarily on notions of congressional expectations. A recent decision concerning tribal capacity to regulate land use on fee land owned by nonmembers reaches such an imcoherent outcome that it is difficult to identify its basis. See infra text accompanying notes 308-30. Finally, the Court in Duro v. Reina, 110 S. Ct. 2053 (1990), which extended Oliphant to protect nonmember Indians from tribal criminal jurisdiction, relied mostly upon dicta in earlier cases and the concerns about civil rights that animated Oliphant. See infra text accompanying notes $248-54$ \& 304-07.

159. Oliphant, 435 U.S. at 212; see also Duro, 110 S. Ct. at 2066 ("If the present jurisdictional scheme proves insufficient to meet the practical needs of reservation law enforcement, then the proper body to address the problem is Congress, which has the ultimate authority over Indian affairs."); $c f$. Merrion, 455 U.S. at 159 ("[T] The Tribe may enforce its severance tax unless and until Congress divests this power, an action that Congress has not taken to date.").

160. 31 U.S. (6 Pet.) 515 (1832).

161. Id. at 561 .

162. See, e.g., Rice v. Rehner, 463 U.S. 713 (1983) (federal statute authorized state regulation of liquor sales in Indian country). 
Indian country on a case-by-case basis. In this area, given the background of the plenary power doctrine, any evident congressional expectations about state authority presumably would heavily influence the outcome. Part Two of this Section assesses the extent to which congressional understandimgs have governed the outcomes of these kinds of cases.

\section{State Exercise of Congressionally Delegated Authority}

The principal federal statute delegating regulatory power over Indian country to states is federal Public Law No. 280, adopted in 1953. ${ }^{163}$ In the current version of that statute, Congress gives six named states $^{164}$ criminal law enforcement respousibility in Indian country withm their borders, as well as seemingly expansive civil jurisdiction. ${ }^{165}$ Other states can opt into this authority by adopting a statute or constitutional amendment. ${ }^{166}$

Public Law 280, a clear congressional diminishment of tribal sovereignty, was adopted in the Terunination Era, ${ }^{167}$ when Congress was taking wide-ranging interest im reducing tribal sovereignty. One would expect, therefore, that any ambignities in Public Law 280 would be interpreted to promote state regulation, not protect tribal sovereignty. In the principal case applying the statute, however, the Court reached a result

163. Act of Aug. 15, 1953, Pub. L. No. 280, 67 Stat. 588 (codified as amended at 18 U.S.C. $\S \S 1161-1162$ (1988), 25 U.S.C. $\$ \S 1321-1322$ (1988), 28 U.S.C. $\S 1360$ (1988)). A comprehensive article on Public Law 280 is Goldberg, Public Law 280: The Limits of State Jurisdiction Over Reservation Indians, 22 UCLA L. REV. 535 (1975).

164. Originally there were five so-called mandatory states: California, Minnesota, Nebraska, Oregon, and Wisconsin. Goldberg, supra note 163, at 537 n.11. Alaska was added in 1958. Id. (citing Act of Aug. 8, 1958, Pub. L. No 85-615, § 2, 72 Stat. 545) (codified at 18 U.S.C. $\S 1162$ (1988)), 28 U.S.C. $\$ 1360$ (1988)). The current codified version includes these six states, with some Indian country in Alaska, Minnesota, and Oregon expressly excepted from the effects of Public Law 280. 18 U.S.C. $\$ 1162$ (a) (1988).

165. The codified statute provides that each of these states

shall have jurisdiction over offenses committed by or against Indians in the areas of Indian country ... [identified in the statute] to the same extent that such state has jurisdiction over offenses committed elsewhere within the state, and the criminal laws of such State ... shall have the same force and effect within such Indian country as they have elsewhere within the State.

18 U.S.C. $\S 1162$ (a) (1988). The civil jurisdiction provision, 28 U.S.C. $\S 1360$ (1988), states: Each of the States ... shall have jurisdiction over civil causes of action between Indians or to which Indians are parties which arise in the areas of Indian country listed . . . to the same extent that such State has jurisdiction over other civil causes of action, and those civil laws of such State... that are of general application to private persons or private property shall have the same force and effect within such Indian country as they have elsewhere within the State.

28 U.S.C. $\S 1360$ (a) (1988).

166. 25 U.S.C. $\$ \S 1321-1322$ (1988) (currently reflects a 1968 amendment providing that a state assumption of jurisdiction over Indian country is conditioned upon tribal approval).

167. For a discussion of the Termination Era, see supra text accompanying 44-46. 
seemingly opposed to the statutory language and the indicia of congressional intent.

In Bryan v. Itasca County, ${ }^{168}$ the Supreme Court unanimously held that a Minnesota county could not impose its nondiscriminatory personal property tax upon a mobile home owned and occupied by an Indian who hived on a reservation located in the county. By conventional interpretive criteria-statutory language and legislative intent-the county's arguments were extremely strong. Section 4(a) of Public Law 280 , the civil jurisdiction provision, seemingly states that civil laws of general apphication-presumably like a nondiscriminatory tax statuteapply in Indian country just as they do elsewhere in the state. ${ }^{169}$ Section 4(b) provides certam exceptions to this grant of civil jurisdiction, but the property at issue in Bryan did not fall withm them. ${ }^{170}$ The expressio unius maxim noted earher ${ }^{171}$ suggests that when a statute contains a list of exclusions, those are the only exceptions to the general rule enbodied im it. Although this maxim is ordmarily of questionable value, ${ }^{172}$ the point about negative implication seems to have force in Bryan, because section 4(b) carefully specifies what it exempts from state authority. By specifically forbidding certain kinds of "taxation," section 4(b) strongly suggests that section 4(a) amounts to a general delegation of taxing authority subject only to the specific exceptions mentioned in section $4(b) .{ }^{173}$

168. 426 U.S. 373 (1976).

169. For the relevant text of the statute, see supra note 165 .

170. Bryan, 426 U.S. at 390. Section 4(b) (codified at 28 U.S.C. $\$ 1360(b)$ (1988)) provides:

[N]othing in this section shall authorize the alienation, encumbrance, or taxation of any real or personal property, including water rights, belonging to any Indian or any Indian tribe, band, or community that is held in trust by the United States or is subject to a restriction against alienation imposed by the United States; or shall authorize regulation of the use of such property in a manner inconsistent with any Federal treaty, agreement, or statute or with any regulation made pursuant thereto; or shall confer jurisdiction upon the State to adjudicate, in probate proceedings or otherwise, the ownership or right to possession of such property or any interest therein.

Section 4(b) fails to exempt the mobile home in question, since it was not "held in trust by the United States" or "subject to a restriction against alienation imposed by the United States."

171. See supra text accompanying note 123 .

172. See supra text accompanying note 124 .

173. The Court in Bryan mentioned only one argument based on statutory text that runs against this interpretation, and the Court buried the point in a footnote in its legislative history discussion. 426 U.S. at 384 n.11. The Court noted that the title to Public Law 280 spoke of conferring " 'jurisdiction on the States ... with respect to criminal offenses and civil causes of action committed or arising on Indian reservations within such States, and for other purposes." "Id. (quoting Pub L. No. 280, H.R. REP. No. 848, 83d Cong., 1st Sess. 3 (1953) (codified as amended at 18 U.S.C. $\S \S 1161-1162$ (1988), 25 U.S.C. $\S \S 1321-1322$ (1988), 28 U.S.C. $\S 1360$ (1988)). The Court also noted that section 4 of Public Law 280 is entitled "State civil jurisdiction in actions to which Indians are parties." Bryan, 426 U.S. at 385 n.11. Although clear language in the body of the statute supposedly controls, rather than inconsistent language in a statutory title, see generally $2 \mathrm{~A}$ SUTHERLAND STATUTES AND STATUTORY CONSTRUCTION $\$ 47.03$ (4th ed. 1984), the references in these titles do create some ambiguity about whether section 4 gives the state legislature authority 
Courts usually take such clear statutory language as good evidence of congressional intent. ${ }^{174}$ The Court in Bryan gamely responded, however, that the interpretation suggested above was foreclosed by the legislative history of the statute and the applicable canons of construction. ${ }^{175}$ But as the Court acknowledged, the legislative history is essentially silent concerning the ineaning of section $4 .{ }^{176}$ Moreover, the canon cited by the Court-"that 'statutes passed for the benefit of dependent Indian tribes ... are to be liberally construed, doubtful expressions being

over Indian country or, alternatively, simply opens the state courts to hear civil cases arising in Indian country. That the Court buried its best textual argunnent in a footnote suggests that it did not consider the apparent ineaning of the statutory language of great importance in reaching its decision.

174. See, e.g., cases cited supra note 21 .

175. Bryan, 426 U.S. at 379.

176. The legislative history did note that section 4 allows state courts to adjudicate civil lawsuits arising in Indian country. Bryan, 426 U.S. at 381-87. The Court in Bryan interpreted this language as pointing to the primary intent of section 4 . Id. But even if true, that interpretation gives ineaning only to the first of the two clauses in section 4(a). The Court interpreted the second clause of section 4(a) as simply a tag-along of the first, allowing state courts to apply state law rules of decision rather than tribal law rules of decision. Id. at 384. This interpretation ignores the apparent independence of the two clauses suggested by the punctuation and by the implications of section 4(b)'s wording.

The Court in Bryan also noted a 1968 amendinent to Public Law 280 that inandates tribal consent before any state can opt into the regime of Public Law 280 in the future. Bryan, 426 U.S. at 386 (citing the ICRA, tit. IV, 82 Stat. 78 (codified at 25 U.S.C. $\$ \S 1321-1326$ (1988)). The provision requiring tribal consent refers to "State jurisdiction acquired pursuant to this subchapter with respect to criminal offenses or civil causes of action." 25 U.S.C. $\S 1326$ (1988). Although this is inconsistent with the plain wording of the original statute, it helped the Court very little in Bryan. As the Court adinitted, under conventional methods of statutory interpretation -which it purported to follow-"the prinary interpretation of $\S 4$ must have reference to the legislative history of the Congress that enacted it rather than to the history of Acts of a later Congress." Bryan, 426 U.S. at 386. To the extent that the tension between the 1953 statute and the 1968 amendment is irreconcilable, the inconsistency could be resolved in a variety of ways. For example, the Court could hold that the taxing authority allowed under section 4 was impliedly repealed for future, optional state assumptions of jurisdiction. That interpretation, of course, does nothing to support the result in Bryan.

The Court made two other observations in favor of its conclusion. First, it noted that the Congress that adopted Public Law 280 was the same Congress that adopted several Termination Acts. Id. at 389. The Court suggested that this Congress "knew well how to express its intent directly when that intent was to subject reservation Indians to the full sweep of state laws and state taxation." Id. A contrary result in Bryan, however, would not have resulted in Public Law 280's duplicating a termination statute. Even under that interpretation of Public Law 280, a tribe would remain a sovereign capable of, among other things, enacting laws goverring its own people so long as they were not inconsistent with state law. Furthermore, the interpretation of section 4(b) rejected in Bryan would have preserved tribal lands, Indian allotments, and rights protected by federal treaty from state interference.

Second, the Court noted that the criminal jurisdiction provision of Public Law 280, section 2(b), contained a similar exception to the one contained in the civil jurisdictional provision of section $4(\mathrm{~b})$. Id. at 391. The inclusion of these restrictions is puzzling. Perhaps it simply reflects congressional intent to protect Indian treaty rights and trust property from loss or interference resulting froin Public Law 280, for example, by a criminal prosecution for the exercise of treaty-based hunting and fishing rights in a manner inconsistent with state law. In any event, it is difficult to see how the inclusion of the exception in the criminal provision suggests anything about the meaning of the civil provision, except perhaps that they were both carelessly drafted. 
resolved in favor of the Indians" "177_-is inapplicable, since Public Law 280 is a statute designed to undermine, not enhance, the autlority of tribes. But lowever phrased, the canons are of little lielp in Bryan, where the statutory language is so strongly opposed to the Court's interpretation and where the Court invoked no specific legislative intent to overcome this language.

Indeed, if one plausibly assumes that the 1953 Congress liad no specific intent on the issue in Bryan and then asks what those legislators would likely have said about the issue at that time, the answer seeins rather clear. Hostile to tribal independence, that Congress would probably lave been surprised by the outcome in Bryan. In addition, those legislators would probably have opposed Bryan's holding because the taxing authority souglit by the Minnesota county would have helped it pay for the responsibilities Public Law 280 had thrust upon it. Thus, as with the otler cases we have examined, Bryan draws little support froin conventional, intentionalist sources of ineaning. ${ }^{178}$

\section{State Regulation Absent Express Federal Delegation}

The Constitution is silent concerning whether states have any authority to regulate in Indian country. ${ }^{179}$ As noted earlier, Chief Justice

177. Bryan, 426 U.S. at 392 (quoting Alaska Pac. Fisheries v. United States, 248 U.S. 78, 89 (1918)).

178. A decade after Bryan, the Court interpreted the criminal jurisdiction provision of Public Law 280 in a sinilarly narrow fashion. In California v. Cabazon Band of Mission Indians, 480 U.S. 202 (1987), the question was whether Indian tribes in California, a Public Law 280 state, were required to comply with California statutes governing the operation of bingo games. Under Bryan, state gambling statutes of a civil nature could not be applied in Indian country by virtue of Public Law 280. California had several relevant criminal statutes, however, that prohibited bingo games with prizes exceeding $\$ 250$ and forbade persons operating the games from being paid for their services. Despite the language of Public Law 280, which states that "the criminal laws of such State shall have the same force and effect within such Indian country as they have elsewhere within the State," the Court in Cabazon Band held that the California criminal statutes regarding bingo were unenforceable in Indian country. 480 U.S. at 212.

Borrowing the analysis of several circuit courts of appeals, the Court in Cabazon Band distinguished "prohibitory" state criminal laws froin "regulatory" ones. Id. at 210. Statutes that are primarily regulatory are sufficiently like civil statutes as to fall within Bryan; conversely, statutes that are primarily prohibitory are so essentially crininal in nature that they apply in Indian country by virtue of Public Law 280. Since the Court thought that California's approach to bingo amounted mostly to toleration and regulation rather than prohibition, it held that California's bingo statutes unay not be applied to the tribes through Public Law 280 even though the statutes specify penalties for their violation. Id. at 211-12.

The Court in Cabazon Band inade no effort to support this outcoine by reference to statutory language or legislative intent. The statute on its face draws no distinction between different types of criminal laws, and the Court cited no legislative history to support such a distinction. The Court's interpretation was thus inconsistent with the plain language of the statute and with the probable legislative expectation of the 1953 "Termmation Era" Congress. As such, it is apparent that Cabazon Band, like Bryan, cannot be supported by reference to any reasonable assumptions concerning congressional intent.

179. As noted earlier, the only provision in the Constitution expressly governing the allocation 
Marshall's opinion in Worcester attempted to lodge in the federal government the exclusive authority to deal with the Indians. ${ }^{180}$ A century and a half later, this flat prohibition against unilateral state assertions of authority has eroded. In light of the plenary power doctrine, one would expect the Court to uplold state regulation in Indian country when the regulation would be consistent witl evident congressional expectations. An examination of the cases reveals, lowever, that congressional intent does not justify their outcomes.

When no federal statute or treaty provides a state with authority to govern Indian country, the tribe seeking to avoid state regulation may invoke two lines of precedent. The first line began in Williams v. Lee, ${ }^{181}$ which lield that a state court could not exercise jurisdiction over an action by a non-Indian inercliant to collect for goods sold on credit to an Indian in Indian country. The Court in Williams created an "infringement test," stating tliat "absent governing Acts of Congress, the question lias always been whether the state action infringed on the right of reservation Indians to make their own laws and be ruled by them."182 The Court unanimously concluded that allowing state court jurisdiction "would undermine the authority of the tribal courts over Reservation affairs." 183

Williams has not controlled later controversies where the exercise of state authority did not directly undermine the tribe's capacity to govern itself. For example, when a state attempts to inipose a statewide, nondiscrimmatory tax on an Indian who lives in Indian country, the state is not directly undermining the ability of the tribe to make and be governed by its own laws. Accordingly, the Court adopted a different theory when it

of power to deal with Indians is the Indian commerce clause, see supra note 8, which provides that Congress has the authority to "regulate Commerce with foreign Nations, and among the several States, and with the Indian Tribes." U.S. CoNST., art. I, § 8, cl. 3. The Court has never held that the Indian commerce clause has a dormant component authorizing federal judicial invalidation of state regulation unduly impeding commerce between tribes and the United States. See Cotton Petroleum Corp. v. New Mexico, 109 S. Ct. 1698, 1713-15 (1989).

180. See supra text accompanying notes 160-62.

181. 358 U.S. 217 (1959).

182. Id. at 220.

183. Id. at 223. Apparently the Court was assuming that the tribal court would apply tribal customary law (non-Indians would call this the common law) to resolve the contract dispute. Thus, the Court implicitly ratified the tribal courts as appropriate entities to make and enforce tribal law. From non-Indian perspectives, at least, perhaps an even easier case for protecting "the right of reservation Indians to make their own laws and be ruled by them" would arise if a tribal council had adopted a commercial code governing contracts for the sale of goods on credit.

It seems obvious that tribal law may differ in significant respects from state law whether it is adopted by a tribal council or constructed from tribal customs by a tribal court. For example, tribal law may allow execution of judgment by seizure of personal property, but not by garnishment, while the state law allows for garnishment of wages. See Joe v. Marcum, 621 F.2d 358 (10th Cir. 1980) (describing enforcement of judgments under the Navajo Tribal Code). 
held, in McClanahan v. Arizona State Tax Commission, ${ }^{184}$ that Arizona could not tax the incoine of an Indian hiving and working in Indian country.

In contrast to the broad presumption of tribal sovereignty underlying Williams, the Court's modern decisions "tend to avoid reliance on platomic notions of Indian sovereignty and to look mstead to the applicable treaties and statutes which define the limits of state power," stated Justice Marshall in McClanahan ${ }^{185}$ McClanahan made clear, however, that "federal Indian law preemption" analysis is different from federal preemption analysis in other areas. ${ }^{186}$ "The Indian sovereignty doctrine," the Court continued, "is relevant . . . not because it provides a definitive resolution of the issues in this suit, but because it provides a backdrop against which the apphicable treaties and federal statutes must be read." 187

One would expect that any discernible congressional expectations would weigh heavily in defining the scope of relevant treaties and legislation. McClanahan, however, is not readily supportable by reference to congressional intent. The 1868 treaty between the United States and the Navajo did not address the general application of state law in Indian country. ${ }^{188}$ The Court in McClanahan pointed to the Arizona Enabling Act, which made it a condition of statehood that Arizona disclaim any right or title to Indian lands. ${ }^{189}$ But the Enabling Act provided an

184. 411 U.S. 164 (1973).

185. Id. at 172.

186. Occasionally the Court has invoked something similar to ordinary federal preemption analysis to hold that a state may not regulate in Indian country. The principal decision is Warren Trading Post v. Arizona Tax Commission, 380 U.S. 685 (1965), holding that a state may not inpose a nondiscriminatory gross proceeds tax upon a federally licensed retail business operating in Indian country. The Court concluded that federal statutes and administrative regulations provide such comprehensive regulation of Indian traders "that no room remains for state laws imposing additional burdens upon [them]." Id. at 690. Warren Trading Post was followed in Central Machinery Co. v. Arizona State Tax Commission, 448 U.S. 160 (1980) (state cannot tax transaction taking place on reservation, even though the merchant had no permanent place of business on the reservation and was not licensed to trade with Indians).

187. McClanahun, 411 U.S. at 172. In a later opinion, Justice Marshall elaborated upon the Indian law preemption inquiry, seeing it essentially as a case-by-case balanciug test that considers federal, tribal, and state interests, and reads ambiguities in federal law generously to protect tribal sovereiguty and independence. White Mountain Apache Tribe v. Bracker, 448 U.S. 136, 143-45 (1980).

188. McClanahan, 411 U.S. at 174 ("The treaty nowhere explicitly states that the Navajos were to be free from state law or exempt from state taxes."). The Court thought that the treaty reflected an intent "to establish the lands as within the exclusive sovereignty of the Navajos under federal supervision." Id. at 175 . Upon reflection, this argument proves too inuch, since following McClanuhun the Court has held that a tribe does not possess all the attributes of sovereignty over Indian country, see supra text accompanying notes 140-59, and that a state may exercise some regulatory authority there. See infra text accompanying notes 195-201.

189. Arizona Enabling Act, cl. 310, 36 Stat. 569 (1910). 
immunity from state taxation for Indian reservation property only, ${ }^{190}$ creating the negative implication that the state could tax income earned by Indians. Next, the Court referred to the Buck Act, ${ }^{191}$ which generally allows states to tax persons living in federal enclaves but contains an exception for reservation Indians. The exception, however, simply carves out reservation Indians from the Buck Act, rather than providing any express immu1nity for Indians from state taxation. ${ }^{192}$ As such, the Buck Act seeins largely irrelevant to the controversy in McClanahan.$^{193}$ All told, the congressional expectations associated with the federal treaty and statutory sources in McClanahan only weakly support its holding. ${ }^{194}$ Again, any coinpelling justification for the decision coines from factors other than congressional imtent.

Since $\mathrm{McClanahan}$, the Court has held that Indians in Indian country inay be subject to state regulation, even under an ambiguous delegation of federal authority, so long as there is no "backdrop" of tribal sovereignty on the facts. ${ }^{195}$ It has also held that, even without a delegation of federal authority, a state may regulate Indians in Indian country

190. "[N] othing herein, or in the ordinance herein provided for, shall preclude the said State froin taxing as other lands and other property are taxed any lands and other property outside of an Indian reservation owned or held by any Indian." Id. at 570 .

191. 4 U.S.C. $\$ \S 105-109$ (1988).

192. 4 U.S.C. $\$ 109$ (1988).

193. The Court also referred to "narrower statutes authorizing States to assert tax jurisdiction over reservations in special situations," and assumed that they were "explicable only if Congress assuined that the States lacked the power to impose the taxes without special authorization." McClanahan, 411 U.S. at 177. The only tax statute the Court cited, however, is one that allows the states to tax mineral production on unallotted tribal lands. See id. at $177 \mathrm{n} .16$. This statute is "explicable" by reference to the history under which Indian lands are imunune froin state taxation; it takes little inagination to assume that this immunity reaches minerals extracted from these lands as well. See HaNdBook of Indian LAw, supra note 7, at 406-12. But cf. Cotton Petroleuin Corp. v. New Mexico, 109 S. Ct. 1698 (1989) (state may tax oil and gas production of non-Indian lessee on Indian lands), discussed at infra text accompanying notes 198-201.

194. The makeweight nature of the opinion in McClanahan is also shown by the Court's suggestion that Public Law 280 undermines Arizona's power to tax. The Court's short discussion of Public Law 280 apparently assuned that Arizona could obtain taxing authority over the Navajo reservation by opting into the civil jurisdiction provision of Public Law 280, McClanahan, 411 U.S. at 177-78. In retrospect, this argument is an embarrassment, since three years after McClanahan, the Court in Bryan v. Itasca County, 426 U.S. 273 (1976), held that the civil jurisdiction provision of Public Law 280 conferred no power to tax upon the states. See supra text accoinpanying notes 16878. McClanahan does contain a footnote reserving the issue under Public Law 280. 411 U.S. at 178 n.18.

195. In Rice v. Rehner, 463 U.S. 713 (1983), the Court held that a federal statute requiring liquor vendors in Indian country to obey "laws of the State" inandates that Indian vendors coinply with state licensing requirements as well as state substantive provisions. Id. at 733-35. The Court found only weak support for federal preeinption of the state licensing requirement because, using the language of McClanahan, there was no significant "backdrop of tribal sovereignty"; until 1953, federal law forbade the sale of liquor in Indian country, and historically the federal government has encouraged states to outlaw sales of liquor to Indians. Id. at 720-29. The Court concluded that "[t]here can be no doubt that Congress has divested the Indians of any inherent power to regulate in this area." Id. at 724. 
so long as the state interest in regulation is significant, and the regulation does not seriously undermine tribal independence. ${ }^{196}$

The Court initially seemed willing to protect even non-Indian businesses operating in Indian country from state taxation in circumstances where the state could not show that its interest in taxation was significant. ${ }^{197}$ Recently, however, Cotton Petroleum Corp. v. New Mexico ${ }^{198}$ inay have abandoned this approach. It appears that states may now tax such busmesses unless the state is shown to have provided absolutely no benefit to Indian country in connection with the activity sought to be taxed. ${ }^{199}$ Justice Stevens' opinion in Cotton Petroleum analogized a nonIndian contractor employed by a tribe to a contractor for the federal

196. See Washington v. Confederated Tribes of the Colville Indian Reservation, 447 U.S. 134 (1980) (state may tax sale of cigarettes by tribe to non-Indians because (1) legal incidence of tax falls on purchaser; (2) federal preemption argument is weak because tribe is attempting to market a tax exemption for a product for which no value is added on the reservation; and (3) state has significant interest in taxing for revenue purposes and for protecting non-Indian vendors from an "artificial" competitive disadvantage); see also Rice, 463 U.S. at 724 (state had significant interest in regulating liquor transactions in Indian country because of spillover effect of those sales outside Indian country).

This line of argument was rejected in California v. Cabazon Band of Mission Indians, 480 U.S. 202 (1987), discussed at supra note 178, wlich held that state regulation of Indian gambling was preempted by the federal interest in tribal economic development. Id. at 215-19. The Court in Cabazon Band declmed to analogize tribal immunity from state gambling regulation to the marketing of an exemption from state taxation, which it had condemned in Confederated Tribes. The distinction between the two cases is a thin one, however; the Court suggested that in Cabazon Band the tribe had "generat[ed] value on the reservations" by building modern facilities and providing services to non-Indians, $i d$. at 219-20, rather than simply "importing a product onto the reservations for immediate resale to non-Indians." Id. at 219; $c f$. New Mexico v. Mescalero Apache Tribe, 462 U.S. 324 (1983) (state regulation of hunting and fishing in Indian country preempted where tribe and federal government regulated extensively, tribe was exploiting its natural resources for economic development by marketing the reservation as a hunting and fishing site, and state demonstrated no spillover effects outside Indian country).

197. See Ramah Navajo School Bd. v. Burean of Revenue, 458 U.S. 832 (1982) (state may not impose its gross receipts tax upon non-Indian contractor building school for Indians in Indian country because (1) federal government heavily regulated construction and education in Indian country; (2) state tax would deplete funds available for Indian education; and (3) state provided no services to the contractor while it was working in Indian country); White Mountain Apache Tribe v. Bracker, 448 U.S. 136 (1980) (balancing of state, tribal, and federal interests precluded state from imposing motor carrier license and use fuel taxes on non-Indian contractor working for tribe in Indian country).

198. 109 S. Ct. 1698 (1989).

199. Catton Petroleum upheld application of a state oil and gas severance tax amounting to over \$2.2 million upon a non-Indian company extracting oil and gas in Indian country. The state demonstrated that it provided some services, worth approximately $\$ 89,000$, related to the company's oil and gas operations in Indian country. Id. at 1704 n.6. New Mexico's provision of services distinguished Cotton Petroleum from Ramah Navajo School Board and Bracker, discussed at supra note 197, where the states were completely uninvolved in on-reservation activity. $I d$. at 1712 . The Court expressly refnsed to impose any requirement of proportionality between the state services provided and the amount of the state tax in question. Id. at 1712 \& n.15. The Court in Cotton Petroleum also noted that the state was providing some regulation of wells located on the reservation, while in the two earlier cases federal and tribal regulation was exclusive. Id. at 1712-13. Although the state court in Cotton Petroleum had found, as a matter of fact, that the state taxes 
government. Beginning in the 1930s, the Court has repudiated the notion that federal contractors are immune froin state taxation under the intergovernmental immunity doctrine. ${ }^{200}$ Justice Stevens could find no reason why contractors with tribes should have any broader tax innmumity. ${ }^{201}$

Congressional imtent has played ouly a marginal role in the postMcClanahan decisions. For example, in White Mountain Apache Tribe v. Bracker, ${ }^{202}$ Ramah Navajo School Board v. Bureau of Revenue, ${ }^{203}$ and Cotton Petroleum, Congress provided extensive regulation of timbering, funding for education, and regulation of oil and gas production in Indian country. In none of these cases is there any indication that Congress had any intention, one way or the other, about whether non-Indian contractors should be immune from state taxation when the practical effect of the tax is borne by the tribe. ${ }^{204}$

As we complete our review of inany of the important areas of contemporary federal Indian law, we have found, contrary to reasonable expectations, that congressional intent cannot explain what the Court has done. In cases like Menominee Tribe, the Court has reached a result inconsistent with the apparent original congressional expectations, despite the contrary pressures of convention (the intentionalist interpretive inodel) in general, and the plenary power doctrine in particular. In other cases, where original congressional expectations on the issue under

imposed no economic burden on the tribe, the Court recognized that the tax surely had some indirect detrimental effect on it. $I d$.

200. See id. at 1706-07 (discussing intergovernmental immunity cases).

201. Id, at 1713:

Any impairment to the federal policy favoring the exploitation of on-reservation oil and gas resources by Indian tribes that might be caused by [these taxes], however, is simply too indirect and too insubstantial to support Cotton's claim of pre-emption. To find preemption of state taxation in such indirect burdens on this broad congressional purpose, absent some special factor such as those present in Bracker and Ramah Navajo School Bd. would be to return to the pre-1937 doctrine of intergovernmental tax immunity. Any adverse effect on the Tribe's finances caused by the taxation of a private party contracting with the Tribe would be ground to strike the state tax. Absent more explicit guidance from Congress, we decline to return to this long-discarded and thoroughly repudiated doctrine.

202. 448 U.S. 136 (1980), discussed at supra note 197.

203. 458 U.S. 832 (1982), discussed at supra note 197.

204. Other post-McClanahan cases are similarly not supportable by reference to congressional intent. Extensive federal regulation was absent in Washington v. Confederated Tribes of the Colville Indian Reservation, 444 U.S. 134 (1980), discussed at supra note 196, but again one heard only silence from Congress on the disputed issue. To the extent that the result in Cabazon Band seems inconsistent with Congress' probable intent for Public Law 280, see supra note 178, its preenption analysis is equally infirm on that score. It follows that congressional intent cannot serve to reconcile Confederated Tribes and Cabazon Band. Rice v. Rehner, 463 U.S. 713 (1983), discussed at supra note 195 , may be consistent with a congressional intent to delegate liquor regulation to the states. Its imposition in Indian country, however, of state licensing requirements in addition to substantive liquor rules seems inconsistent with the later decision in Cabazon Band, which recognized a distinction for purposes of Public Law 280 criminal jurisdiction between prohibitory and regulatory penal statutes. 
litigation seem nonexistent, the Court lias necessarily looked for other guidance to resolve the dispute. Even here, however, the Court has sometimes pretended to adhere to congressional imtent, as in Solem, and has failed to admit that it is performing any innovative lawmaking role. Our survey of botli kinds of cases raises three obvious questions: What are the outcome-determinative considerations in tliese cases? Wliy has the Court embraced them? Can they be aggregated into any meaningful approach to federal Indian law? It is to these inquiries that we now turn.

II

BEyond CONGRESSIONAL INTENT: DyNAMIC AND PRACTICAL FACTORS IN FEDERAL INDIAN LAW

Identifying tlie factors that trumped the statutory results suggested by congressional expectations in the cases discussed in Part I is a formidable task. The Court rarely even suggests what those factors might be, mucli less explains wliy they should liave more force than congressional intent in a particular litigation context. Even so, a fuller probing of the cases allows a reconstruction that largely ameliorates the incoherence suggested in Part I. This analysis suggests that a variety of important traditions, background norms, and contextual factors trumped original congressional expectations. Sections II(A) and II(B) document that each case discussed in Part I can be explained by one or more of the following values: enforcing a tradition of protecting Indian rights, avoiding congressional expectations that are obsolescent in the current Indian context, applying manageable judicial standards, and defining civil rights by measuring the appropriate scope of sovereiguty within a political community.

Unfortunately, this inquiry reveals a deeper, even inore troubling mcolierence. These four values often conflict, exacerbating the tension between formalism and contextualisin found in public law. Ultimately, it is liard to escape the conclusion that these decisions, althougli individually defensible, in the aggregate simply represent ad loc judicial judginents. $^{205}$ Section II(C) shows how the Indian law cases of the 1988

205. One might argue that the cases simply reveal a judicial rejection of intentionalism as a foundational method of statutory interpretation, particularly since intentionalism has been criticized from a variety of perspectives. For an overview, see infra text accompanying notes 360-82; Eskridge \& Frickey, supra note 22, at 325-32. Although these attacks on intentionalism are not universally accepted, they do provide an obvious rationale for the nonoriginalist perspective of the cases: the Court abjured intentionalism and decided each case for other reasons.

This simple explanation must be rejected, however, for in each case discussed in Part I the Court purported to reach its result through conventional statutory interpretation, which is largely intentionalist in orientation. Indeed, in Solem (the reservation diminishment case), the Court went so far as to justify its holding by reference to congressional intent even though in an earlier section of the opinion it had persuasively explained that no such intent existed. See supra text accompanying notes 66-77. In addition, the cases contain very few suggestions that intentionalism might work 
Term reinforce the conclusion that the Court has no organizing method for approaching Indian law probleins.

Part II ends up casting serious doubt on whether any underlying theory might work in federal Indian law. Accordingly, Part III turns more directly to theory in this field and suggests a theory of interpretation as practical reasoning. Part III suggests that this antiformalist approach is both descriptively and normatively supportable. ${ }^{206}$

\section{A. A Wavering Tradition of Protecting Indian Rights, Avoiding Obsolescent Congressional Intent, and the Search for Manageable Judicial Standards}

The Indian law canons of interpretation cannot fully explain the cases discussed in Part $I$, for the canons do not purport to truinp the seemingly clear congressional intent found in soine of those cases. Canons are also notoriously unrehiable predictors of judicial behavior, ${ }^{207}$ and in many cases that Indians have lost, like Oliphant, ${ }^{208}$ the canons are honored only in the breach. The canons should not be dismissed entirely, however, because they demonstrate a longstanding, although waverimg, judicial tradition of protecting Indian rights against all but direct congressional assaults.

These canons, and the aspirations they represent, descend from Chief Justice John Marshall. The notion that the federal government has some unique responsibility toward tribes arose first in dicta in Cherokee Nation v. Georgia. ${ }^{209}$ The Cherokee Nation sought to invoke the Court's original jurisdiction to hear its complaint that Georgia was attempting to destroy the tribe's sovereignty by endeavoring to apply state law to Cherokee lands set aside by federal treaty. Chief Justice Marshall described the Cherokee Nation "as a state, as a distinct political society, separated from others, capable of managing its own affairs and governing itself."210 Because the Cherokee Nation was neither a foreign nation nor a state of the United States, however, the Court could not exercise original jurisdiction. For Chief Justice Marshall, Indian tribes are "doniestic

mischief in the circumstances under review. For these reasons, it seems safe to conclude that the Court did not overtly abandon intentionalism. Nonetheless, the results in these cases provide stark evidence that the Court did not embrace intentionalism as the foundational theory controlling decisionmaking in federal Indian law.

206. For a more elaborate examination of this perspective on interpretation, see infra text accompanying notes 383-435.

207. See generally W. ESKRIDGE \& P. FRICKEX, supra note 53, at 639-96.

208. See supra text accompanying notes 140-59; infra text accompanying note 248; see also Mountain States Tel. \& Tel. Co. v. Pueblo of Santa Ana, 472 U.S. 237, 257 (1985) (Brennan, J., dissenting) ("The Court's interpretation . . . flouts the fiduciary relationship owed to Indian tribes and the canons of construction that serve to preserve that relationship.").

209. 30 U.S. (5 Pet.) I (1831).

210. Id. at 16 . 
dependent nations" whose relation with the federal government "resembles that of a ward to his guardian."211

This dictum provides the basis for the "trust relationship" between the United States and Indian tribes. For niany years, the doctrine was more sword than shield, for the Court invoked it to justify the congressional plenary power doctrine. ${ }^{212}$ Even today the trust relationship adds little of substance to Indian riglits. ${ }^{213}$ Nevertheless, the trust relationship

211. Id. at 17. Chief Justice Marshall categorized the tribes as "domestic dependent nations" that "occupy a territory to which we assert a title independent of their will, which must take effect in point of possession when their right of possession ceases. Meanwhile they are in a state of pupilage. Their relation to the United States resembles that of a ward to his guardian." Id. at 17.

212. In United States v. Kagama, 118 U.S. 375, 385 (1886), the Supreme Court held that it was within Congress' power to pass the Indian Major Crimes Act, cli. 341, § 9, 23 Stat. 385 (1885) (codified as amended at 18 U.S.C. $\$ 1153$ (1988)), which makes it a federal crime for an Indian to commit certain significant crimes (like murder) in Indian country, even if the victim is also Indian. The Court in Kagama did not rely upon the only express grant of legislative power to Congress involving Indians-that Congress may regulate "Commerce . . . with the Indian Tribes," U.S. CONST. art. I, $\S 8$, cl. 18-because it concluded that the statute was far removed from the regulation of commerce. Kagama, 118 U.S. at 378-79. Instead, the Court held:

It seems to us that this is within the competency of Congress. These Indian tribes are the wards of the nation. They are communities dependent on the United States. Dependent largely for their daily food. Dependent for their political rights. They owe no allegiance to the States, and receive from them no protection. Because of the local ill feeling, the people of the States where they are found are often their deadliest enemies. From their very weakness and helplessness, so largely due to the course of dealing of the Federal Government with them and the treaties in which it has been promised, there arises the duty of protection, and with it the power. . . .

...

The power of the General Government over these remnants of a race once powerful, now weak and diminished in numbers, is necessary to their protection, as well as to the safety of those among whom they dwell. It must exist in that government, because it never has existed anywhere else, because the theatre of its exercise is within the geographical linits of the United States, because it has never been denied, and because it alonc can enforce its laws on all the tribes.

Id. at 383-85 (emphasis in original). The trust relationship, the dependent condition of the tribes, and the perception that it was necessary for some Anglo-American government to have authority over tribes fused together in Kagama to support the congressional plenary power doctrine. For cases following this aspect of Kagama, see United States v. Sandoval, 231 U.S. 28, 46 (1913) (all dependent Indian conimunities, including those without treaty relations with United States, are subject to congressional plenary power); Lone Wolf v. Hitchcock, 187 U.S. 553, 566 (1903) (Congress may unilaterally abrogate Indian treaty).

213. As the Mitchell cases suggest, see supra text aceompanying notes $82-110$, monetary recovery for breaches of fiduciary responsibility is bedeviled with problems of sovereign immunity. Moreover, Congress often requires the executive branch to implement conflicting programs concerning Indian rights, and, notwithstanding the trust relationship, the Court will not interfere with Congress' considered allocation of duties. See Nevada v. United States, 463 U.S. 110, 128 (1983) (the "Government cannot follow the fastidious standards of a private fiduciary" when Congress imposes duties on executive branch inconsistent with single-minded protection of Indian resources).

In marked contrast to the Mitchell cases, the Court in Seminole Nation v. United States, 316 U.S. 286 (1942), assessed damages against the United States for paying money owed under a treaty according to the directions of a tribal council rather than to individual members of the tribe as an annuity, as the treaty provided. There are at least two important distinctions between Seminole Nation and Mitchell. First, in Seminole Nation Congress had enacted a special jurisdictional statute 
may cast at least an aspirational aura over federal Indian law, and it provides an important basis for the canons. ${ }^{214}$

A year after Cherokee Nation, Chief Justice Marshall returned to the conflict between the Cherokee and Georgia. In probably the most important decision in federal Indian law, Worcester v. Georgia, ${ }^{215}$ the Court held that Georgia law did not apply on Cherokee lands protected by federal treaty. A critical issue was whether the Cherokee had agreed to abandon their sovereignty. One treaty provision could be so read:

" $[F]$ or the benefit and comfort of the Indians, and for the prevention of injuries or oppressions on the part of the citizens or Indians, the United States, in congress assembled, shall have the sole and exclusive right of regulating the trade with the Indians, and managing all their affairs, as they think proper." 216

Chief Justice Marshall found it "inconceivable" that the Cherokee would have understood the provision as extending beyond matters of trade to destruction of their political existence. Such an interpretation would, he said, be contrary to the "spirit" of this and other Indian treaties that contemplated that the tribe in question retained sovereignty to wage war. "It would convert a treaty of peace covertly into an act, annihilating the political existence of one of the parties. Had such a result been imtended, it would have been openly avowed."217

Thus began the notion that treaties are to be interpreted as the Indians would have understood them, and that drastic invasions of Indian rights should be found only where coinpelled by clear treaty language. Chief Justice Marshall's creation of these canons is based in part on empirical assuinptions about the probable expectations of the tribe and about the bargaining process between the tribe and the federal government. But the canons have a heavy normative component as well: The Chief Justice assumed not just good faith on the part of federal negotiators, but also a federal responsibility to ensure forthright negotiating and clear drafting to avoid "covert" losses of Indian rights.

Simce Cherokee Nation and Worcester, the Court has frequently

clearly waiving sovereign immunity for "all legal and equitable claims" that might be involved. In the Mitchell cases, by contrast, no clear waiver of sovereign immunity was present. Second, in Seminole Nation Congress had squarely placed the executive branch in a position identical to that of a private trust company: under the treaty, the executive branch was obligated to establish a trust fund and pay annually the income from the fund to the members of the tribe. In Mitchell, however, the executive branch became the manager of Indian resources without any such clear indication that Congress intended to establish fiduciary duties. See infra text accompanying notes 238-42.

214. See HANDBOOK OF INDiAN LAw, supra note 7, at 221-25.

215. 31 U.S. (6 Pet.) 515, 561 (1832).

216. Id. at 553 (quoting Treaty of Hopewell, Nov. 28, 1785, United States-Cherokee Indians, art. IX, 7 Stat. 18, 20) (emphasis added).

217. Id. at 554 . 
invoked a tradition of preserving Indian rights from both state and congressional encroachment, unless Congress has spoken clearly to the contrary. ${ }^{218}$ This tradition, as with all public law traditions rooted in value judgments, lias not protected tribes in all cases. Moreover, tlie Court has drifted with the congressional tide, so that in eras of assimilationist federal policy the Court lias soinetimes abandoned tlie tradition altogether. ${ }^{219}$ In other cases, liowever, the Court has invoked the tradition in the face of a contrary contemporary federal policy. ${ }^{220}$ Although sometimes wavering, tlue tradition seeins to be part of the web of beliefs in the American legal interpretive community. ${ }^{221}$

In several of the cases discussed in Part I, the tradition of preserving Indian riglits led to a "dynamic" interpretation of federal statutes-that is, an interpretation in tension witls the expectations of the enacting Congress and perliaps with the statutory language, but conipatible with conteniporary values and context. ${ }^{222}$ Menominee Tribe, the case involving treaty-based liunting and fishing rights, provides an obvious example. ${ }^{223}$ Although that decision seenis inconsistent with statutory language and the likely origmal congressional expectations, it is easily coinpatible with both prior and subsequent developments. The Termination Act was a sharp departure froin the policy of pronioting

218. For a brief overview, see HaNDBOOK of INDIAN LAW, supra note 7, at 221-25.

219. See, e.g., Tee-Hit-Ton Indians v. United States, 348 U.S. 272, 288-89 (1955) (Termination Era decision holding that Congress may unilaterally extinguish original Indian title without any requirement to pay just compensation); Lone Wolf v. Hitchcock, 187 U.S. 553, 566 (1903) (Allotment Era decision holding that Congress may unilaterally abrogate Indian treaty).

220. See, e.g., Wilhams v. Lee, 358 U.S. 217, 223 (1959) (Termination Era decision holding that tribal court had exclusive jurisdiction over action brought by non-Indian trader against Indian to collect on goods sold on credit in Indian country); Winters v. United States, 207 U.S. 564, 576-77 (1908) (Allotment Era decision holding that tribe had federally protected water rights that trump generally applicable state law).

221. The tradition is elegantly presented, perhaps a bit too optimistically, in C. W1LKINSON, supra note 6. Recent commentators on the canons of statutory interpretation have also noted this tradition. See Eskridge, Public Values in Statutory Interpretation, 137 U. PA. L. REV. 1007, 103234, 1047-48 (1989); Sunstein, Interpreting Statutes in the Regulatory State, 103 HARV. L. REV. 405 , 483-85 (1989). For further discussion, see infra text accompanying notes 425-26.

222. "Dynamic" interpretation in Indian law is somewhat different from that in other areas. William Eskridge, who originated the term, had in mind cases in which legislative expectations have become obsolete over time. In this situation, one starts the inquiry with the original legislative expectations and evaluates whether they remain compatible with the broader legal terrain. See generally Eskridge \& Frickey, supra note 22, at 345-62 (suggesting an evolutive model of statutory interpretation). In federal Indian law, one must start one step further back in tine becausc the longstanding judicial tradition of preserving Indian rights makes statutes or policies that invadc tribal prerogatives questionable from the start.

223. See supra text accompanying notes $42-61$. 
tribal self-government that Congress had adopted in the Indian Reorganization Act of 1934. ${ }^{224}$ Moreover, although Congress only recently formally repudiated the termination pohicy, ${ }^{225}$ in practical terms the policy was remarkably short-lived. ${ }^{226}$ In 1966, two years before Menominee Tribe was decided, a congressional committee concluded that the termination policy had put the Menominee in "desperate straits." Thus, it is understandable tliat the Court in Menominee Tribe was not enthusiastic about enforcing the probable intentions of the Congress that adopted the Termination Act in 1954. It is unfortunate that Menominee Tribe lacks any hint that such factors were controlling.

The tradition of preserving Indian rights and the rejection of an obsolescent congressional policy also explain Bryan, the case concerning whether Public Law 280 granted states the authority to tax in Indian country. ${ }^{228}$ The assimilationist views of the 1953 Congress that adopted the statute were out of sync both with prior federal policy and with subsequent developments. The Court in Bryan was somewhat more forthcoming than it lad been in Menominee Tribe about its consideration of post-enactment developments. In a footnote, the Court acknowledged commentary suggesting that general civil regulatory control of states over tribes would have "a devastating impact on tribal governments."229 It next stated that "[p]resent federal policy appears to be returning to a focus upon strengthening tribal self-government."230 Finally, the Court quoted a lower court opimion for the proposition that "courts 'are not obliged in ambiguous instances to strain to implement [an assimilationist] policy Congress has now rejected, particularly where to do so will interfere with the present congressional approach to what is, after all, an ongoing relationship." "231

224. For an overview of the Indian Reorganization Act of 1934, 48 Stat. 984 (codified as amended at 25 U.S.C. $\$ \$ 461-479$ (1988)), see HANDBOOK OF INDIAN LAW, supra note 7, at 147-51.

225. See Hawkins-Stafford Elementary and Secondary School Improvement Amendments of 1988, Pub. L. No. 100-297, tit. V, § 5203(f), 102 Stat. 385 (codified at 25 U.S.C. § 2502(f) (1988)) ("The Congress hereby repudiates and rejects House Concurrent Resolution 108 of the 83d Congress and any policy of unilateral termination of Federal relations with any Indian Nation.")

226. For example, both presidential candidates in 1960 disassociated themselves from it, the Kennedy and Johnson administrations only grudgingly implemented it, and President Nixon formally rejected it in 1970, only two years after Menominee Tribe was decided. See HaNDBook of INDIAN LAW, supra note 7, at 182-88. Congress formally restored tribal status to the Menominee in 1973. Menominee Restoration Act of 1973, Pub. L. No. 93-197, 87 Stat. 770 (codified at 25 U.S.C. $\S \S$ 903-903f (1988)).

227. H.R. ReP. No. 1924, 89th Cong., 2d Sess. 2 (1966).

228. See supra text accompanying notes 168-78.

229. Bryan v. Itasca County, 426 U.S. 373,389 n.14 (1976).

230. Id.

231. Id. (quoting Santa Rosa Band of Indians v. Kings County, 532 F.2d 655, 663 (9th Cir. 1975)). California v. Cabazon Band of Mission Indians, 480 U.S. 202 (1987), the other major Public Law 280 case, discussed at supra note 178, followed this same policy of preventing "the destruction of tribal institutions and values," id. at 208, when it distinguished between state "criminal/ 
In addition to the termination policy and the delegation of authority to states in Public Law 280, the cases discussed in Part I reveal another obsolete policy, that of allotinent-the breakup of reservations into allotments for individual Indians and surplus land for non-Indian homesteading. Allotment, arguably the most disastrous federal policy ever adopted for peaceful tribal Indians, destroyed most of the Indian land base. ${ }^{232}$ The Indian Reorganization Act of $1934^{233}$ restored tribal sovereignty as a federal policy and repudiated the allotment policy. It prohibited future allotments and protected the remaining allotments by extending into perpetuity the period in which the federal government would loold them in trust. It also halted the destruction of tribal landholding by encouraging the executive branch to maintain the integrity of reservations.

Although abandoned for half a century, the allotment policy continues to work extraordinary mischief. Solem, the reservation diminishment case, ${ }^{234}$ shows that the influx of non-Indian land owners has raised difficult questions concerning the location of reservation boundaries. Solem contains inany contradictory coinments about congressional intent. The driving force for its holding seems to have been policy considerations related to current demographics; ${ }^{235}$ again, the dynanic element seems crucial to judicial decisionmaking.

The Court in Solem noted "the obvious practical advantages of acquiescing to de facto dimimishment," explaining that state and local governinents are burdened when a predominately non-Indian area is still considered Indian country, and that a jurisdictional morass results when an area largely consisting of Indian allotments is held to be outside

prohibitory" laws, which apply in Public Law 280 jurisdictions, and "civil/regulatory" laws, which under Bryan do not.

In Rice v. Rehner, 463 U.S. 713, 730-31 (1983), discussed at supra note 195, the Court held that 18 U.S.C. $\$ 1161$ (1988), which requires liquor vendors in Indian country to operate "in conformity ... with the laws of the State," required an Indian vendor to comply with both state substantive liquor law and state licensing requirements. The Court in Rice refused to distinguish between substantive regulation and licensing requirements, even though the distinction appears analogous to the "prohibitory/regulatory" line drawn in Cabazon Band. Rice may be distinguished from Cabazon Band on two grounds: the delegation to state authority is narrower, and it arose in a context where, at least for the Justices, the need for state regulation is not obviously outmoded.

232. Indians lost more than two-thirds of their land base from 1887 to 1934, when Congress abandoned the allotment policy. See HANDBOOK OF INDIAN LAw, supra note 7, at 138. In addition to the surplus lands initially severed from the tribes, allotted lands werc often lost by individual Indians when their allotments became alienable, frequently through fraudulent land transactions. See A. Gibson, The American Indian: Prehistory to the Present 507-10 (1980). For a recent discussion challenging many of the conventional understandings of allotment, see McChesney, Government as Definer of Property Rights: Indian Lands, Ethnic Externalities, and Bureaucratic Budgets, 19 J. LEG. STUD. 297 (1990).

233. 48 Stat. 984 (codified as amended at 25 U.S.C. $\S \S 461-479$ (1988)).

234. 465 U.S. 463 (1984); see supra text accompanying notes 66-77.

235. Solem, 465 U.S. at $471-72$. 
Indian country. ${ }^{236}$ In Solem, the text of the surplus lands statute, its legislative history, and even subsequent treatment of the reservation by Congress, the courts, and the executive branch left the location of the reservation's boundaries uncertain. The only thing the Court found clear was what happened to the reservation after the surplus lands statute was enacted. Under the circumstances, concluded the Court, "it is impossible to say that the opened areas . . . have lost their Indian character."237 Although Solem provides little guidance for later cases, it does sensitively consider statutory evolution, current values, and coherence with the broad legal landscape.

The Mitchell cases ${ }^{238}$ also illustrate the Court's concern for other important considerations involving allotments. In the Mitchell cases, the plaintiff allottees had no alternative but to rely upon federal management of their lands ${ }^{239}$ and to seek dannages for mismanagement of timber allotments. As the dissenters in Mitchell I and the majority in Mitchell II noted, the only effective form of relief, both to compensate the victims and to deter future mismanagement, was an award of damages against the federal government. The holding in Mitchell $I$ that under the General Allotment Act the government has no monetary liability for mismanaging allotments was extremely harsh, but it was consistent with probable original congressional intent. One need not rest, however, upon intentionalism to support the result im Mitchell $I$. The right asserted there ran up against a canon cutting against the Indian law canons: an award of damages against the government requires a clear congressional waiver of sovereign immunity. ${ }^{240}$

236. Id. at $471 \mathrm{n} .12$. If a predominately non-Indian area is inside a reservation, it is in "Indian country" under the statutory definition. See supra note 63 . If an area is outside a reservation but consists of checkerboarded land ownership in which some parcels are Indian allotments, the allotments are still considered "Indian country" under the statutory definition. Id. The admimistration of government functions is made more difficult in either circumstance.

237. Id. at 480 . The Court noted that $55 \%$ of the allotments were on opened lands. Id. at 480 n.24. Tribal authorities and the Bureau of Indian Affairs have regulated these opened areas. About two-thirds of the tribe's members hived in the opened areas, and Indians inade up about half of the overall population of the areas. Id. at $479-80$.

238. See supra text accompanying notes $82-110$.

239. Allotments frequently have passed by intestate succession, leaving many allotinents held in small fractional shares by too inany individuals to allow effective manageinent by any of them. See generally Comment, Too Little Land, Too Many Heirs-The Indian Heirship Land Problem, 46 WASH. L. REV. 709 (1971) (authored by Ethel J. Williams) (analyzing potential solution to the "progressive fractionation" of Indian lands due to the heirship policies). The allotments are often too small in acreage for farming or ranching to be economically self-sustaining, and thus for practical reasons the federal government leases many adjoining allotments as one parcel. Some allotments, such as one in the middle of an allotted forest that is to be timbered, may be impossible for an individual to manage in any event. See generally HANDBOoK of INDIAN LAw, supra note 7, at 624-26; Chambers \& Price, Regulating Sovereignty: Secretarial Discretion and the Leasing of Indian Lands, 26 STAN. L. REV. 1061 (1974) (discussing the role the Secretary of the Interior should play in leasing Indian lands).

240. Although the sovereign immunity canon might be normatively questionable, see Sunstein, 
It appears that a more normatively attractive factor than sovereign immunity alone probably influenced the Court in Mitchell $I$ : the uncertain ramifications of holding the government financially responsible for fiduciary breaches under the General Allotment Act. With no express statutory duties available that could be extended by inplication or analogy, the Court would have been required to develop the fiduciary duties under the General Allotment Act on a case-by-case basis. The executive branch could fairly complain of lack of notice of these new, judicially constructed duties. Providing damages for their breach might seem like an unforeseeable, retroactive imposition of liability. It is not surprising that the Court refused to enter this unknown terrain, where potential government hability might be enormous and a flood of cases might appear inevitable. Although there were powerful normative reasons for awarding money damages in Mitchell $I$, other factors of an institutional nature, such as the need for manageable judicial standards, counselled caution.

How, then, could the Court in Mitchell II allow damages to these same plaintiffs? A significant difference between the two Mitchell cases is that in Mitchell II the federal government allegedly violated its own timber management statutes in ways that foreseeably harmed plaintiffs; it did not breach some general, undefined fiduciary duties supposedly arising from the General Allotment Act. Mitchell II simply holds the government responsible for violating express statutory duties and other responsibilities implicitly following from those duties. Under Mitchell II, judges are not required to create fiduciary duties out of whole cloth

supra note 221, at 506 (appendix labeling the sovereign immunity waiver canon "obsolete"), recent cases continue to repeat it. See supra text accompanying notes 102-06.

The most persuasive argument that Mitchell $I$ was wrong contends that the General Allotment Act, as a statute dealing with Indians, should have been broadly construed according to the Indian law canons notwithstanding the sovereigu immunity problem. See Newton, The Federal-Indian Trust Relationship After Mitchell, 31 CATH. U.L. REV. 635 (1982). Essentially, if the Tucker Act provides a waiver of sovereign immunity in these cases, as Mitchell II held despite contrary language in Mitchell $I$, the question in both Mitchell cases is simply whether some statute expressly or impliedly provides a cause of action for damages against the federal government for allotment mismanagement. The General Allotment Act provides no express cause of action, nor can an implied one be easily constructed based on probable original congressional intent. Nonetheless, the statute does use the word "trust" to describe the duties of the executive branch, and liberal construction of that word, according to the Indian law canons, could lead to finding an implied cause of action. Since assumedly the issue is not one of sovereign immunity but rather one of implied causes of action, the Indian law canons, not the sovereign immunity canon, should prevail.

Although not without force, this argument fails to recognize that whether the issue in the Mitchell eases is labeled as one of sovereign immunity or an implied cause of action, the practical question is the same: Should the federal treasury be subjected to damages? The federal courts have a tradition of opening the federal coffers to injured persons only when Congress has consented in a rather visible fashion. Furthermore, the General Allotment Act expressly imposed no substantial duties upon the executive branch around which one might construct a cause of action. It was through later developments, both statutory and practical, that the federal government ended up managing much allotted land. 
and define the elements of the cause of action for breach of those duties. This approach lessens judicial intrusion into executive affairs. Moreover, it seems difficult for the executive branch to complain about being held accountable to requirements that Congress imposed upon it.

When the Court in Mitchell II concluded that the federal timber manageinent statutes coinpelled compensation if breached, the Court was really saying that the circumstances in both Mitchell cases compelled the payment of compensation as a normative matter, but that only in the second case were judicially manageable standards available on which to base the award of damages. ${ }^{241}$ As the Court said in Mitchell II, "the statutes and regulations" at issue "establish a fiduciary relationship and define the contours of the United States' fiduciary responsibilities."242

Martinez, the tribal membership case, ${ }^{243}$ also demonstrates the interplay of the three factors identified above: the judicial preference for protecting Indian independence, an unenthusiastic approach to congressional intentions that seem out of sync with prior and subsequent developments, and enforcement of judicially manageable standards. The legislative history of the Indian Civil Rights Act indicates some congressional desire to preserve a sphere of tribal self-government while protecting Indians froin abuse. Unfortunately, the statute provides no help in mediating these cross-cutting concerns. The issue in Martinez-whether federal courts may hear claims about how a tribe chooses to define its

241. Another helpful way to understand the different outcomes of Mitchell $I$ and Mitchell $I I$ is to note that in Mitchell $I$ the government argued that it had not waived its sovereigu immunity. 445 U.S. at 537-38. The Court agreed and held that the Tucker Act, 28 U.S.C. $\$ 1491$ (1988), is " "only a jurisdictional statute" " that does not " "create any substantive right enforceable against the United States for money damages.' " 445 U.S. at 538 (quoting United States v. Testan, 424 U.S. 392, 398 (1976)). In Mitchell II, however, both the government and the plaintiffs agreed that the Tucker Act does constitute a waiver of sovereign immunity. See Note, Indians May Sue for Breach of Federal Trust Relationship: Umited States v. Mitchell, 26 B.C.L. REv. 809, 831 n.293 (1985). Presumably the government's abandonment of its position concerning the Tucker Act taken in Mitchell I helped the two "swing Justices"-Justice Marshall, the author of both Mitchell cases, and Justice Blackmun, the author of Testan-to take different positions in the two Mitchell decisions.

242. 463 U.S. at 224. Mitchell II is subject to a variety of readings. It might narrowly hold that damages are available only when the executive branch violates explicit statutory or regulatory duties to Indians. It could suggest more broadly that when statutes or regulations assigu the executive branch the role of "general manager" of Indian resources and provide a variety of specific managerial duties, the executive branch should be considered a trustee subject to those general duties of good business practices that are not inconsistent with federal statutes or regulations. This broader reading of Mitchell II still allows much more easily constructed judicial standards than those in Mitchell I. Many of the implicit responsibilities of the government as general manager can be constructed by extension or analogy froin express statutory and regulatory duties. Nonetheless, both the narrower and the broader readings of Mitchell $I I$ are consistent with the quotation in the text about the federal management statutes establishing the "contours" of federal responsibility. There are other plausible readings of Mitchell $I I$ as well, and my discussion of it and the other cases surveyed should be read as heuristic.

243. Santa Clara Pueblo v. Martinez, 436 U.S. 49 (1978); see supra text accompanying notes 114-39. 
own members-goes to the core of tribal sovereignty itself. The Court in Martinez took account of the fundamental threat to tribal existence posed by the precise issue before it, and considered as well the general pohicy of preserving tribal self-government, ${ }^{244}$ although, as in Bryan, the inost direct acknowledgeinent is buried in a footnote. ${ }^{245}$

The Court in Martinez lacked ready-inade standards for applying the rights guaranteed by ICRA in the tribal context. The lower federal courts that had assumed jurisdiction under ICRA had engaged in a painstaking, case-by-case process of atteinpting to apply AngloAmerican conceptions of civil rights in the tribal context without obliterating tribal traditions. ${ }^{246}$ As in Mitchell $I$, the Court in Martinez seened reluctant to commit the judicial resources necessary to inap such foreign terrain, in part because of the dubious capacity of federal judges to act effectively. Unlike in Mitchell $I$, however, the Court in Martinez acknowledged that these factors were being considered. ${ }^{247}$

What can be said of the cases discussed in Part I that exhibit less judicial sohicitude toward Indians than do Menominee Tribe, Bryan, Solem, Mitchell II, and Martinez? Oliphant, holding that tribal courts have no criminal jurisdiction over non-Indians, ${ }^{248}$ seems inconsistent with the tradition of protecting tribal rights. In that case, the treaty between the United States and the tribe was silent on tribal criminal jurisdiction, and no federal statute divested the tribe of that authority. If the canons of interpretation had any controlling power throughout federal Indian law, they should have led to a different outcoine in Oliphant.

244. 436 U.S. at 59-64 (noting Congress' intent to promote the "well-established federal 'policy of furthering Indian self-government" ") (quoting Morton v. Mancari, 417 U.S. 535, 551 (1974)).

245. The Court stated:

A tribe's right to define its own membership for tribal purposes has long been recognized as central to its existence as an independent political community. Given the often vast gulf between tribal traditions and those with which federal courts are more intimately familiar, the judiciary should not rush to create causes of action that would intrude on these delicate matters.

Id. at $72 \mathrm{n} .32$ (citations omitted).

246. See supra note 135 and accompanying text.

247. The Court stated:

By not exposing tribal officials to the full array of federal remedies available to redress actions of federal and state officials, Congress may also have considered that resolution of statutory issues ...., and particularly those issues likely to arise in a civil context, will frequently depend on questions of tribal tradition and custom which tribal forums may be in a better position to evaluate than federal courts. ... [T]ribes remain quasi-sovereign nations which, by government structure, culture, and source of sovereignty are in many ways foreign to the constitutional institutions of the Federal and State governments. As is suggested by the District Court's opinion im this case, efforts by the federal judiciary to apply the statutory prohibitions ... in a civil context may substantially interfere with a tribe's ability to maintain itself as a culturally and politically distinct entity.

Martinez, 436 U.S. at 71-72 (citations and footnotes omitted); see also id. at 73 n.32, quoted at supra note 245 .

248. See supra text accompanying notes 140-59. 
There was no evidence of any clear congressional intent to divest Indian sovereignty.

Oliphant, however, does share at least one feature with the cases discussed above. Had tribal courts been allowed to prosecute nonIndians, a key issue would have been the ineaning of ICRA in such cases. Should the rights guaranteed criminal defendants by ICRA be applied to a non-Indian defendant under the same definitions used by state or federal courts applying the Bill of Rights directly? If so, the strain on tribal resources would be enormous, and the tribal courts would be required to abandon traditional methods of resolving disputes. If ICRA's guarantees should be interpreted in light of the tribal context even for non-Indian defendants, the tribal courts-and the federal courts upon habeas corpus review-would have their hands full constructing these standards.

ICRA, moreover, does not incorporate some important protections that the Bill of Rights grants criminal defendants in state or federal court, such as trial by an "impartial jury"249 and, in many circumstances, free appointed counsel if a defendant cannot afford representation. ${ }^{250}$ This raises a serious question in Oliphant: if tribal courts have jurisdiction over non-Indians, what is the source of that jurisdiction? If it flows from congressional expectations, or perhaps is confirmed by the legislative history of ICRA, ${ }^{251}$ could a non-Indian defendant claim that the tribal court is operating under delegated federal authority ${ }^{252}$ and must

249. ICRA allows a criminal defendant in tribal court to request a trial "by jury of not less than six persons." 25 U.S.C. $\$ 1302(10)$ (1988). Compare this language with that of the sixth amendment: "In all criminal prosecutions, the accused shall enjoy the right to a speedy and public trial, by an impartial jury of the State and district wherein the crime shall have been committed ...." U.S. CONST. amend. VI. Since the drafting strategy of ICRA was to borrow verbatim the provisions of the Bill of Rights, the absence of language about an "impartial" jury could not have been inadvertent.

250. ICRA provides that a tribal court cannot deny a criminal defendant the right "at his own expense to have the assistance of counsel for his defense" 25 U.S.C. $§ 1302(6)$ (1988) (emphasis added). As originally enacted, ICRA permitted a tribal court to impose on a criminal defendant a penalty no greater than a term of six months or a fine of $\$ 500$, or both. Pub. L. No. 90-284, tit. II, $\S 202(7), 82$ Stat. 77, 77 (1968) (codified as amended at 25 U.S.C. \$ 1302(7) (1988)) (limits raised to $\$ 5,000$ or one year, or both, in 1986, Pub. L. No. 99-570, $\$ 4217,100$ Stat. 3207, 3207-146). The Constitution requires the availability of free defense counsel if an indigent criminal defendant ultimately receives any jail time. See Scott v. Illinois, 440 U.S. 367 (1979). Thus, the incarceration of an impecunious defendant without making free counsel available beforehand violates the Constitution if done by a federal or state court, but would not violate ICRA if done by a tribal court.

251. See supra text accompanying notes 152-53.

252. Cf. Settler v. Yakima Tribal Court, 419 F.2d 486, 489 (9th Cir. 1969) (decided before the effective date of ICRA; the court found that tribal court was developed in part as a federal agency), cert. denied, 398 U.S. 903 (1970); Colliflower v. Gariand, 342 F.2d 369, 378-79 (9th Cir. 1965) (also deeided prior to the enactment of ICRA; the court found tribal courts were historically "arms of the federal government"). Congress may delegate federal authority to a tribe to regulate non-Indians. See, e.g., United States v. Mazurie, 419 U.S. 544, 555-56 (1975) (Congress may grant tribes authority to license non-Indians to sell liquor in Indian country). 
comply with all constitutional guarantees notwithstanding the limitations of ICRA? Conversely, if tribal judicial power flows from inherent tribal sovereiguty, could Congress' failure to extinguish tribal jurisdiction amount to a denial of the non-Indian defendant's constitutional rights, at least in some situations that would have to be considered on a case-bycase basis? ${ }^{253}$

Oliphant's flat holding against tribal court criminal jurisdiction over non-Indians, therefore, may be supported by some of the same institutional factors underlying Martinez's flat rejection of the federal court's injunctive authority to enforce ICRA. It may be no coincidence that Oliphant and Martinez were decided two months apart. Although Oliphant can be more fully explained on a different basis, ${ }^{254}$ the difficulties of determining manageable judicial standards and the interest in avoiding problematic hitigation may be factors that the Court considered. As with all the factors evaluated in Part II, these considerations are unrelated to any evident congressional expectations.

From the standpoint of protecting Indian rights, avoiding obsolescent congressional expectations, and applymg manageable judicial standards, the most puzzling cases discussed in Part I are probably McClanahan and its progeny, concerning the state power to tax in Indian country independent of any delegation of federal authority. ${ }^{255}$ When a state attempts to tax an individual Indian (McClanahan) or a non-Indian company doing business in Indian country by contract with a tribe (Cotton Petroleum), the state's assertion of authority does not directly undermine the ability of the tribe to make and be governed by its own laws. Moreover, the taxes involved are nondiscriminatory and could not have been intended to destroy tribal independence or to disadvantage Indians selectively. These cases are unlike Worcester, where Georgia attempted to preempt tribal law, replace it with state law, and incorporate the Cherokee into the state.

Yet in many circumstances state taxes will undermine tribal financial resources. Indeed, im each of the cases involving non-Indians, it was assumed that the tax would be passed back to the tribe or would otherwise reduce the money available to the tribe. ${ }^{256}$ Thus, these state taxes

253. To be sure, there may be no federal action in this context that could invoke constitutional protections. Since Congress has divested tribal sovereignty to some extent under ICRA, however, perhaps the lines of divestment must withstand at least some rational basis inquiry.

254. See infra text accompanying notes 304-07.

255. See supra text accompanying notes 184-201.

256. See Cotton Petroleum Corp. v. New Mexico, 109 S. Ct. 1698, 1713 (1989) (Court assumed that state tax imposed on non-Indian oil and gas lessee placed some limit on profitability of Indian oil and gas leases); Ramah Navajo School Bd. v. Bureau of Revenue, 458 U.S. 832, 842 (1982) (Court stated that a state tax on a non-Indian contractor's gross receipts from school construction on reservation would deplete the funds available for Indian schools); White Mountain Apache Tribe v. Bracker, 448 U.S. 136, 149 (1980) (Court found that state taxes on non-Indian logging of Indian 
are impediments to the federal policy of tribal independence, which is manifested today in a desire to encourage tribal economic development. ${ }^{257}$

It would have been simple enough for the Court in these cases to start witlı Worcester's holding that state law does not apply in Indian country and then conclude that, absent a clear stateinent to the contrary by Congress, the rule of Worcester still holds, even thougli today reservation Indians are citizens of the state in which tley he and consumers of some state resources. Instead, McClanahan requires a case-by-case consideration of whetler the state tax is "preempted" by federal statutes and treaties, supposedly read generously to preserve tribal immunity. Since no federal statute or treaty expressly preempts the state law, these cases necessarily becoine unguided judicial excursions identifying and weighing the state interests in taxation and the federal policy on a particular matter (such as on-reservation oil and gas production in Cotton Petroleum) for a particular reservation. The Court seems to have ignored the value of manageable judicial standards embraced by many of the other cases. Contrary to the tradition of preserving Indian independence, tribes are disadvantaged in litigation about state taxation to the extent that McClanahan suggests tliat state law applies unless it can be shown to be preenipted. ${ }^{258}$

Recently, the Court in Cotton Petroleum may have attenipted to construct more inanageable judicial standards by suggesting that nonIndian contractors for tribes, like federal contractors, sliould not liave tax-exempt status, absent unusual circumstances. ${ }^{259}$ Cotton Petroleum clarifies little, however, since it did not purport to overrule any earlier

land would undermine the federal policy of permitting Indians to receive logging profits); Washington v. Confederated Tribes of the Colville Indian Reservation, 447 U.S. 134, 154-58 (1980) (Court assumed that allowing the state to tax cigarette purchases by non-Indians would take away market advantages enjoyed by tribal cigarette shops).

257. See, e.g., Pommersheim, Economic Development in Indian Country: What Are the Questions?, 12 AM. INDIAN L. REv. 195 (1984) (analyzing the goals and strategies of economic development in Indian country).

258. See Canby, The Status of Indian Tribes in American Law Today, 62 WASH. L. Rev. 1, 7 (1987) (stating that adoption of the preemption analysis in McClanahan effectively reversed the previous presumption that states do not have power over Indian tribes unless delegated by Congress). In Montana v. Blackfeet Tribe, 471 U.S. 759 (1985), the Court held that a tribe was immune from state taxation of activities in Indian country without clear word to the contrary from Congress. The Court interpreted McClanahan and Bryan v. Itasca County, 426 U.S. 373 (1976), as embracing this same presumption for the taxation of individual Indians. Blackfeet Tribe, 471 U.S. at 765-66. The Court did not explain how these flat presumptions can be made consistent with McClanahan's preemption analysis, which seemingly requires a particularized inquiry into the treaties, statutes, and relevant federal, state, and tribal interests on a case-by-case basis.

259. See supra notes 198-201 and aecompanying text. 
cases in which state taxes in rather similar circuunstances were held preeinpted. ${ }^{260}$ But in another sense Cotton Petroleum stands in stark contrast to most of the other cases discussed in Part I. By stating that "[s]tates and tribes have concurrent jurisdiction over the same territory"261 - that is, over lands within the reservation - the Court in Cotton Petroleum used the McClanahan preemption analysis to undermine dramatically the degree of tribal independence suggested by most of the other decisions.

As in many other cases, the Court in Cotton Petroleum considered the values of creating judicially inanageable standards and avoiding obsolescent policies, but used these saine values to markedly different effect. The Court used judicially managed standards to treat the tribes like the federal government and to treat contractors working for either the tribe or the federal government in a similar manner. The supposedly obsolescent policy avoided in Cotton Petroleum is the "thoroughly repudiated" doctrine of intergovernmental tax immunity - a doctrine never before repudiated in federal Indian law.

Cotton Petroleum also demonstrates that the Indian law canons are soinetimes honored in the breach. The Court noted that "ambiguities in federal law are, as a rule, resolved in favor of tribal independence," then failed to give the canons any force. No federal statute indicated whether the state could tax this oil and gas production in Indian country; thus, under the canons, the state-not the tribe or its contractor-should

260. See supra note 199 for a discussion of how the Court distinguished Cotton Petroleum from Ramah Navajo School Board and Bracker. The Court also distinguished Cotton Petroleum's facts from those in Montana v. Crow Tribe of Indians, 484 U.S. 997 (1988), stating that in Crow Tribe Montana's unusually large tax on coal extracted in Indian country inposed a "substantial burden on the Tribe." Cotton Petroleum, 109 S. Ct. at 1713 \& n.17. In the first decision in the courts of appeals since Cotton Petroleum, Hoopa Valley Tribe v. Nevins, 881 F.2d 657 (9th Cir. 1989), the Ninth Circuit narrowly interpreted Cotton Petroleum as not abandoning case-by-case adjudication as used in Ramah Navajo School Board. Id. at 659.

261. Cotton Petroleum, 109 S. Ct. at 1716. Earlier, the Court stated:

[A] multiple taxation issue may arise when more than one State attempts to tax the same activity. If a unitary business derives incoine from several States, each State may only tax the portion of that income that is attributable to activity within its borders. Thus, in such a case, an apportionment formula is necessary in order to identify the scope of the taxpayer's business that is within the taxing jurisdiction of each State. In this case, however, all of Cotton's leases are located entirely within the borders of the State of New Mexico and also within the borders of the Jicarilla Apache reservation. Indeed, they arc also within the borders of the United States. There are, therefore, three different governinental entities, each of which has taxing jurisdiction over all of the non-Indian wells. The federal sovereign has undoubted power to prohibit taxation of the Tribe's lessees by the Tribe, by the State, or by both, but since it has not exercised that power, concurrent taxing jurisdiction over all of Cotton's on-reservation leases exists. Unless and until Congress provides otherwise, each of the other two sovereigns has taxing jurisdiction over all of Cotton's leases.

Id. at 1713-14 (citations and footnote ounitted).

262. Id. at 1707 . 
have borne the consequences of the statute's ambiguity. ${ }^{263}$

Taken to its logical conclusion, Cotton Petroleum would seem to require the overruling of $\mathrm{McClanahan}$ itself. Since federal employees do not share the federal government's immunity from state taxation, ${ }^{264}$ after Cotton Petroleum it is hard to see why tribal employees, much less tribal inembers as in McClanahan, should be immune from state income taxation. Yet Cotton Petroleum gives no hint that McClanahan is in any danger on its own facts.

Cotton Petroleum is the most recent reminder that federal Indian law decisions are a chaotic lot. It may do us hittle good to demonstrate, as Part I has done, that congressional intent does not control these decisions, for perhaps there is no overall guiding principle to be found in them. Before we can assess that prospect, however, we must review some other factors that seemingly influenced the decisions under review.

\section{B. Civil Rights and the Concept of Political Community}

Another factor illuminating the cases in Part I is the value of protectimg civil rights by defining the scope of pohtical cominunity. This approach first appears in Cherokee Nation and Worcester, where Chief Justice Marshall saw tribes as self-governing political communities different in kind, not just in degree, from Anglo-American institutions of government. A half-century later, when federal Indian policy was strongly antagomistic to tribal independence, this tradition was carried on in one of the most interesting opinions in federal Indian law.

In Ex parte Crow Dog, ${ }^{265}$ an Indian leader named Crow Dog murdered the Brule Sioux chief, Spotted Tail, in Indian country. To avoid an ongoing feud, Spotted Tail's family resolved the matter according to tribal custom by accepting compensation froin Crow Dog's family. Federal

263. In the Indian Oil Act of 1927, ch. 299, § 3, 44 Stat. 1347, 1347 (current version at 25 U.S.C. $\$ 398$ c (1988)), Congress expressly provided that states could impose such taxes on production in Executive Order reservations, the kind of reservation in Cotton Petroleum. See Cotton Petroleum, 109 S. Ct. at 1710 . The 1938 statute that governed the mineral leasing at issue in Cotton Petroleum contained no such express congressional authorization of state taxation. See Indian Mineral Leasing Act of 1938, ch. 198, 52 Stat. 347 (codified at 25 U.S.C. $\$ \S 396 \mathrm{a}-396 \mathrm{~g}$ (1988)); see also Cotton Petroleum, 109 S. Ct. at 1710. The 1938 Act generally repealed the 1927 Act, and thus-independent of the canons-a good argument arises on the face of the statutes that Congress knew how to authorize state taxation and failed to do so. See Cotton Petroleum, 109 S. Ct. at 1710 (noting that the general repeal clause in the 1938 Act repealed all prior inconsistent acts). Even if the intervening partial demise of federal intergovernmental tax immunity and the particulars of the two statutes complicate the outcome, see id. at 1710-11, one would think that enough ambiguity exists for the canons to produce an outcome favorable to the Indian interest.

264. See Graves v. New York ex rel. O'Keefe, 306 U.S. 466 (1939) (no implied constitutional immunity from income taxation for the salaries of federal or state employees).

265. 109 U.S. 556 (1883). 
authorities were not satisfied, however, and Crow Dog was tried in federal court for murder and sentenced to death. ${ }^{266}$ In a revealing opinion, the Supreme Court granted a writ of habeas corpus on the ground that the federal court had no jurisdiction to prosecute Crow Dog.

At that time, Indian reservations were considered federal enclaves where federal criminal laws applied, except for a statutory exception denymg federal jurisdiction over crimes committed by one Indian against another Indian. ${ }^{267}$ The federal government argued that this exception had been impliedly repealed for the Sioux in an 1868 treaty $^{268}$ and in a later agreeinent einbodied in an 1877 federal statute. ${ }^{269}$ The statute provided that the Sioux "shall be subject to the laws of the United States."270 The treaty stated that the United States shall punish offenders according to federal law in two circuinstances: (1) "[i]f bad inen anong the whites, or among other people subject to the authority of the United States, shall commit any wrong upon the person or property of the Indians"; and (2) "[i]f bad men ainong the Indians shall coininit a wrong or depredation upon the person or property of any one, white, black, or Indian, subject to the authority of the United States, and at peace therewith."271 Under the treaty the Sioux could be seen as submitting to the authority of the United States. Since the 1877 statute seeins to mandate that conclusion, both treaty clauses could be read to fit Crow Dog's situation. Under the first clause, he could be a "bad inan" who victimized a Sioux Indian; under the second, he could be a Sioux Indian who committed a crime against "any one." Under either reading, he would be subject to federal authority.

The Court found no federal criminal jurisdiction under the treaty. It wrote that "it is quite clear froin the context that this does not cover the present case of an alleged wrong committed by one Indian upon the person of another of the same tribe."272 The Court read the treaty as involving two sovereign parties in a "we/they" relationship. From the federal perspective, the first clause governed crimes committed against the Sioux by "whites and their allies," and the second concerned crimes

266. For a brief account of the background of Crow Dog, see V. DeloRiA, JR. \& C. LYTLE, AMERICAN INDIANS, AMERICAN JUSTICE 168-69 (1983). A recent, extended discussion is found in Harring, Crow Dog's Case: A Chapter in the Legal History of Tribal Sovereignty, 14 AM. INDIAN L. REV. 191 (1989).

267. The current version of this statute, 18 U.S.C. $\S$ I152 (1988), extends into Indian country "the general laws of the United States as to the punishment of offenses" committed in federal enclaves. Id. It continues, however, to contain an exception for "offenses committed by one Indian against the person or property of another Indian." Id.

268. Treaty with the Sioux Indians, April 29, 1868, 15 Stat. 635.

269. Act of February 28, 1877, ch. 72, 19 Stat. 254.

270. Id. art. 8, I9 Stat. at 256.

271. Treaty with the Sioux Indians, art. I, 15 Stat. at 635.

272. Crow Dog, 109 U.S. at 567. 
committed against those persons by the Sioux. ${ }^{273}$ In essence, the Court concluded that the Sioux's independent political community remained intact not just in spite of, but in part because of, the treaty language.

Nor did the 1877 statute cliange the result. In fuller context, the statute, which ratified an agreement with the Sioux, provided: "[A]nd Congress shall, by appropriate legislation, secure to them an orderly government; they shall be subject to tlie laws of the Umited States, and eacli mdividual shall be protected $\mathrm{m}$ his rights of property, person, and life."274 This language could imdicate an intent to destroy the Sioux's independent pohtical commumity. For the Court, however, that interpretation was inconsistent with the nature of an agreement between sovereigus. The Court explained:

The pledge to secure to these people, with whom the United States was contracting as a distinct political body, an orderly government, by appropriate legislation thereafter to be framed and enacted, necessarily implies, having regard to all the circumstances attending the transaction, that among the arts of civilized hife, which it was the very purpose of all these arrangements to introduce and naturalize among them, was the highest and best of all, that of self-government, the regulation by themselves of their own domestic affairs, the maintenance and order and peace among their own members by the administration of their own laws and customs. ${ }^{275}$

For the Court, the Indians were "to be subject to the laws of the Umited States, not in the sense of citizens, but, as they liad always been, as wards subject to a guardian; not as individuals, constituted members of the political commumity of the United States, witli a voice in the selection of representatives and the framing of the laws, but as a dependent community" that "might become a self-supporting and self-governing society" under federal guidance. ${ }^{276}$ In Crow Dog, the Court strongly asserted the notion that preserving, even shoring up, the Indian political commumity was in fact a federal policy-indeed, was a federal policy of positive normative consequence.

At first glance, the principles in Crow Dog might seem indistinguishable from the wavering tradition of preserving Indian rights we identified earlier. A fundamental distinction can be drawn, however. Protecting Indian rights, includimg a right of self-determination, could be seen simply as preserving cultural umqueness and allowing a racial minority breathing room from the assimilatiomist pressures of the broader society.

273. Id. at 567-68.

274. Act of February 28, 1877, art. 8, 19 Stat. at 256.

275. Crow Dog, 109 U.S. at 568.

276. Id. at 568-69. Crow Dog contains two essential policy presumptions: tribal independence and reforming the Indians' "savage nature." See infra note 284. Apparently the first was considered an important component of bringing about the second. 
Yet Crow Dog, even more than Cherokee Nation and Worcester, seems to make a stronger assertion concerning Indian tribes. Tribes are not simply culturally distimct sub-communities in which persons of color aggregate by virtue of shared heritage, values, interests, and experiences; mstead, tribes are juridical, political communities empowered by law to regulate "their own domestic affairs." 277 In federal Indian law, the "we/ they" distimction is not primarily cultural (between the dominant white society and minority sub-communities that include the Native American community) but sovereign (between the United States and each tribe).

The difference has profound consequences. It may be, as William Eskridge $^{278}$ and Cass Sunstein ${ }^{279}$ have suggested, that judges do-and should-embrace a canon that requires a clear legislative statement before disadvantaged groups like racial minorities can be harmed by positive law. Whatever the merits of this proposed canon, it is more than an expansion of the well-established canon that presumes no federal invasion of tribal sovereignty without a clear congressional statement. The "disadvantaged groups canon" implicitly recognizes that racial minorities and other subordinated groups, though formally full members of the American political community, may have less opportunity than others to protect themselves in American legislatures. A canon designed to preserve tribal sovereignty, such as that flowing from Cherokee Nation, Worcester, and Crow Dog, has a fundamentally different premise. Tribal Indians are formally members of American society only to a limited extent, and they also owe the responsibilities of citizenship to their tribes. In this situation, pre-colonial group sovereignty and normative concern about colonization and its resultimg deprivations are important, distingnishing factors.

Worcester and Crow Dog illustrate the difference nicely. A United States citizen who is a member of a racial minority group is subject to the criminal jurisdiction of the federal and state courts. Under Worcester, however, state courts have no jurisdiction over an Indian who commits a crime in Indian country, absent some federal delegation of authority such as Public Law $280 .{ }^{280}$ In Crow Dog, a federal statute had expressly carved out of federal criminal jurisdiction those crimes where both the

277. Id. at 568.

278. Eskridge, supra note 221 , at 1032-34.

279. Sunstein, supra note 221 , at $472-73$.

280. Absent a delegation of authority from Congress, the only instance in which a state court may assert criminal jurisdiction over an offense that occurred in Indian country is if both the perpetrator and the victim are non-Indian. See United States v. McBratney, 104 U.S. 621,624 (1882). Since there is no federal statutory basis for this holding, and federal jurisdiction to prosecute the perpetrator wonld be consistent with federal statutory language, it is commonly assumed that McBratney was wrongly decided. See, e.g., Clinton, Criminal Jurisdiction over Indian Lands: $A$ Journey Through a Jurisdictional Maze, 18 ARIz. L. REV. 503, 524-26 (1976). 
victim and perpetrator were Indian. That statutory exception remains im effect today, ${ }^{281}$ although federal law has been modified as a result of $\mathrm{Crow}$ Dog so that federal courts may prosecute certain Indian-to-Indian crimes of major magnitude. ${ }^{282}$ Except for those crimes, tribal courts still have exclusive jurisdiction over Indian-to-Indian offenses. ${ }^{283}$

For the Court in Crow Dog, the concept of the Indian political commumity turned on more than formal notions of representation and practical notions of communal distinctiveness. In essence, the tribe's political distinctiveness made Crow Dog a civil rights case in a narrow sense infrequently considered today-tlie illicit expansion of sovereignty over a member of a different political commumity. ${ }^{284}$

Notions of the distinctive Indian political commumity endure today. For example, Martinez imdicates that tribes contmue to have plenary power over their own members absent congressional intervention. Moreover, tribes may tax even nonmembers who do busmess in Indian country. ${ }^{285}$ Yet the precise concern about civil rights in Crow Dog may seem archaic because Indians today are citizens of the United States as well as of the state in which they live. ${ }^{286}$ Even so, several of the cases discussed in Part I seem heavily infiuenced by the dual aspects of political community and civil rights.

281. 18 U.S.C. $\S 1152$ (1988).

282. Indian Major Crimes Act of 1885 , ch. $341, \S 9,23$ Stat. 362,385 (codified as amended at 18 U.S.C. $\S 1153$ (1988)).

283. See, e.g., D. Getches \& C. Wilkinson, supra note 5, at 414. Technically speaking, the relevant distinction is now meinber/nonmember rather than Indian/non-Indian. See supra note 140.

284. In an illuminating (and ethnocentric) passage, the Court explaimed:

It is a case where, against an express exception in the law itself, that law, by argument and inference only, is sought to be extended over aliens and strangers; over the members of a commumity separated by race, by tradition, by the instincts of a free though savage life, from the authority and power which seeks to impose upon them the restraints of an external and unknown code, and to subject thein to the responsibilities of civil conduct, according to rules and penalties of which they could have no previous warning; which judges them by a standard inade by others and not for them, which takes no account of the conditions which should except them from its exactions, and makes no allowance for their inability to understand it. It tries them, not by their pecrs, nor by the custoins of their people, nor the law of their land, but by superiors of a different race, according to the law of a social state of which they have an imperfect conception, and which is opposed to the traditions of their history, to the habits of their lives, to the strongest prejudices of their savage nature; one which measures the red man's revenge by the maxims of the white man's morality.

Crow Dog, 109 U.S. at 571.

285. See Kerr-McGec Corp. v. Navajo Tribe of Indians, 471 U.S. 195 (1985) (tribe may tax mineral lessee on reservation); Merrion v. Jicarilla Apache Tribe, 455 U.S. 130 (1982) (tribe may tax oil and gas produced on reservation).

286. In 1924, Congress granted citizenship to all "Indians born within the territorial limits of the United States." Act of June 2, 1924, ch. 233, 43 Stat. 253 (codified as amended at 8 U.S.C. $\S 1401$ (a)-(b) (1988)). Prior to that date, many Indians had obtained citizenship through the provisions of more limited statutes or treaties. See generally HaNDBOOK OF INDIAN LAW, supra note 7 , at $142-43$. 
Several cases have asked whether any umique Indian political community had survived the ravages of time and the fluctuations of federal policy. In Menominee Tribe, the Court essentially maintained the status quo $\mathrm{m}$ the face of a formal termination of tribal sovereignty, preserving a surviving Indian political community that Congress shortly thereafter formally restored to tribal status. In Solem, not only could the surplus lands statute have formally extinguished Indian sovereignty over what had been Indian lands, but the subsequent influx of non-Indian settlers into the area could also liave worked a de facto termination of the tribal political community. The Court in both Menominee Tribe and Solem was hesitant to find a destruction of the tribal political coinmunity merely by the enactment of federal legislation, and the communities in both cases had survived as a practical matter. ${ }^{287}$

If a discrete Indian political community exists, Crow Dog suggests that it has authority to regulate all "doniestic affairs."288 Martinez is a bold, modern example of this principle. ${ }^{289}$ As the Court in Martinez noted, defining a group's own membership is at the core of the authority of a political community. ${ }^{290}$ Yet the ineinbership rule at issue in that case looks, at least to many Anglo-Americans, like indefensible gender discrimination. ${ }^{291}$ Thus, Martinez presents a situation, unlike Crow Dog, in which a judicial concern for Indian civil rights might undermine the policy favoring preservation of surviving Indian political comnunities.

The result in Martinez suggests a variety of conflicting conclusions. In one sense, the tension between civil rights and political community may be more illusory than real. When Martinez married outside her tribe after the passage of the tribe's membership ordinance, she was on notice that children of the marriage would not qualify for membership. If she did not agree with the membership rule, she had at least three alternatives: resign from tribal membership, marry within the tribe, or cliange the rule by appropriate tribal decisionmaking mechanisms. In

287. Although, unlike in Solem, see supra text accompanying notes 66-77, Menominee Tribe failed to note any consideration of the nature of the Menominee political community following formal termination, a brief for the tribe stressed that the Menominee had continued their group character after the implementation of the Termination Act. See Supplemental Brief for the Menominee Tribe at 9-13, Menominee Tribe of Indians v. United States, 391 U.S. 404 (1968) (No. 187). The brief states that it was filed, on the occasion of reargument in the case, in response to questions that arose in the initial oral argument. Id. at 1-2; see also C. WILKINSoN, supra note 6, at 75-76 ("the Justices showed considerable interest in whether Mestominee tribal existence survived termination").

288. See supra text accompanying note 275.

289. Santa Clara Pueblo v. Martinez, 436 U.S. 49 (1978).

290. See supra note 245 .

291. For an insightful discussion of Martinez from this and other perspectives, see Resnik, Dependent Sovereigns: Indian Tribes, States, and the Federal Courts, 56 U. CHI. L. REv. 671 (1989) (concluding that Martinez is a case eluding any simple answer). 
effect, the right asserted in Martinez is not a civil right within the Indian political community involved.

In another sense, however, the preceding discussion amounts to begging the question. ${ }^{292}$ Just how traditional was the tribe's rule? It was adopted at least in part to keep the tribe's membership from expanding rapidly so that tribal resources could be conserved. But there are many other, gender-neutral, ways to accomplish the same goal. To what extent, if any, did the federal government encourage the rule? The Secretary of the Interior had approved the tribal inembership ordinance; in addition, the federal government also had a financial interest im keeping tribal membership small, since for purposes of many federal programs, enrolled tribal membership status determines eligibility.

Perhaps the rule was based in part on the notion that male inembers are more likely than female members to live $\mathrm{m}$ and contribute to the tribal commumity when they are partners to a "mixed marriage." The Court in Martinez did not examine this assumption or any other plausible basis for the rule. The Court's failure to face the issue of gender discrimination leaves itself open to the feminist critique that a court may find itself more willing to prefer political commumity over civil rights when those asserting the riglits have traditionally been viewed as appropriate subjects of societal dommation. Paradoxically, however, these complexities may have provided the inipetus in Martinez to avoid entering uncharted domains without readily cognizable judicial standards. ${ }^{293}$

The Court recently provided inore evidence of the tension between civil rights and the notion of an Indian political community. Mississippi Band of Choctaw Indians v. Holyfield ${ }^{294}$ concerned twin children of an unmarried couple who were both members of the same tribe and lived on the reservation. The motlier had left to give birtl elsewhere, and both parents had consented to the children's adoption through a state court. The parents apparently were attempting to avoid the strictures of the Indian Child Welfare Act of 1978 (ICWA), ${ }^{295}$ which requires that a tribal court ratlier than a state court control the adoption of Indian children domiciled on a reservation. ${ }^{296}$ The state court assumed jurisdiction

292. See id. at $705-12$ for a more thorough analysis.

293. See supra text accompanying notes $246-47$. I agree with Vine Deloria, Jr. and Clifford Lytle that Martinez was "a very difficult case that involved two explosive contemporary issues: the status of women within the tribe and the right of a tribe to determine its own meinbership." $V$. DeLORIA, JR. \& C. LYTLE, supra note 266, at 133. One could attribute the Court's decision either to a plausible assessment of congressional intent, but see supra text accompanying notes 114-39, or to a faith in tribal court enforcenent of ICRA (about which the Court probably knew nothing). It seems more rcasonable to conclude that practical factors, such as those discussed in the text, had more outcome-determinative weight.

294. 109 S. Ct. 1597 (1989).

295. 25 U.S.C. $\S \S 1901-1903$ (1988).

296. Holyfield, 109 S. Ct. at 1601 (citing 25 U.S.C. $\$ 1911$ (1988)). 
and placed the children with a non-Indian family. By the time the case reached the Supreme Court, the children had lived with that family for three years. Both Indian parents had urged the Court to leave the children with the non-Indian family. ${ }^{297}$ The Court acknowledged the painful situation, ${ }^{298}$ but nonetheless concluded that under the language and legislative history of ICWA the adoption decree had to be vacated and the matter transferred to the tribal court for resolution.

In reaffirming the authority of the Indian political community, as recognized by Congress in ICWA, did Holyfield deny civil rights to the Indian parents? According to Holyfield, Congress had definitively resolved the tension between political commumity and civil rights in this situation.

ICWA, as interpreted in Holyfield, assumes that a tribal political community must be able to protect against its own eventual destruction. In considering ICWA, Congress examined starthing statistics showing that state social agencies and courts were removing Indian children from their families and placing them in non-Indian settings at sucl rapid rates that the long-terin survival of Indian culture was threatened. ${ }^{299}$ ICWA says, in essence, that the Indian political community should decide the hard questions of custody and adoption of tribal children in the absence of any pressure to assimilate. If they disagreed, the Indian biological parents in Holyfield had a choice: they could have avoided ICWA by clianging their domicile to somewhere off the reservation or by resigning their tribal membership. ${ }^{300}$ If they and others like them wish to retain the benefits of tribal membership, they must act as tribal citizens in a way that avoids undermining the tribe's survival. ICWA establishes that with tribal citizenship come responsibilities as well as rights. ${ }^{301}$

297. Id. at 1611 (Stevens, J., dissenting).

298. Id. (opinion of the Court).

299. Id. at 1599-602.

300. The statute provides that the tribe has exclusive jurisdiction over adoption proceedings "involving an Indian child who resides or is doiniciled within the reservation." 25 U.S.C. § 1911(a) (1988). "Indian child" is defined as a child who is "either (a) a ineinber of an Indian tribe or (b) is eligible for ineinbership in an Indian tribe and is the biological child of a ineinber of an Indian tribe." 25 U.S.C. $\S 1903$ (4) (1988). Thus, Indian parents could defeat ICWA jurisdiction by renouncing their tribal inembership so long as the child herself was not somehow already a member of the tribe. Moreover, even in that circumstance, perhaps the child, or the parents on her behalf, could renounce her membership. If the child remains an "Indian child," however, exclusive tribal jurisdiction is absent if the child is domiciled off the reservation (as she would be if living with a parent who had changed domicile to somewhere off the reservation). In that circuinstance, there can be state court jurisdiction over adoptions, and although there is a presumption that the state court should transfer the matter to a tribal court for resolution, either parent may effectively veto that transfer and kcep the matter in state court. See 25 U.S.C. $\$ \S 1911(b), 1912$ (1988).

301. It may seem harsh that Congress has required tribal Indians to choose between their civil rights as American citizens and membership in the tribal political coinmunity in this context. Would courts allow Congress to subject other American citizens to sucl tragic choices? A more careful analysis may suggest, however, that the tension between United States citizenship and tribal 
In addition to providing the tribe with the authority to regulate its domestic affairs, the notion of pohitical community protects tribes and their inembers from regulation by outsiders. Crow Dog is a prime exainple. McClanahan and Bryan, as cases protecting Indians from state taxation absent clear congressional approval, stand for the same proposition..$^{302}$ As explained earlier, these cases are difficult to reconcile with the relevant statutory language and congressional intent. They make sense, lowever, if the Court's goal is to retain for the tribe the ability to regulate its own "domestic affairs" and to avoid the imposition of taxation scheines adopted by others and ill-suited to the tribal situation. They stand for the proposition that tribal Indians living in Indian country are citizens of the United States first (under the plenary power doctrine), the tribes second, and the states third, and then only to the extent that Congress chooses.

At first glance, Cotton Petroleum, which considered a non-Indian contractor for a tribe coinparably situated to a federal contractor, might seem similar in the way it defines the relevant (here, non-Indian) political coinmunity. Since the practical effect of the tax in Cotton Petroleum apparently largely fell on the tribe and not on the non-Indian contractor, ${ }^{303}$ lowever, the similarity between McClanahan and Cotton Petroleum looks like one of forin and not substance.

The flip side of the "we/they" approach of Crow Dog is illustrated by Oliphant's holding that tribes cannot criminally prosecute nonIndians. Indeed, the Court in Oliphant relied extensively upon Crow Dog concerning the inequity of judging people "by a standard inade by others and not for thein." ${ }^{304}$ For the Court, "[t]hese considerations, apphed here to the non-Indian rather than Indian offender, speak equally strongly against the vahidity of respondents' contention that Indian tribes, although fully subordinated to the sovereignty of the Uinited States, retain the power to try non-Indians according to their own customs and procedure." ${ }^{305}$ Conventional sources of law, sucl as treaty and

membership is more apparent than real. Tribal Indians are citizens of the United States and the states in which they live, and they are members- "citizens"-of their tribes as well. Other American citizens are citizens of only the first two sovereigns. The choice the parents had in Holyfield was whether to retain citizenship in all three sovereigns, with the attendant benefits and burdens, or to resign from the third to escape certain burdens at the cost of certain benefits. In this sense, they had more options of citizenship than other American citizens.

302. Bryan v. Itasca County, 426 U.S. 373 (1976), is discussed at supra text accompanying notes 168-78. McClanahan v. Arizona Tax Commission, 411 U.S. 164 (1973), is discussed at supra text accompanying notes 184-93. See also Montana v. Blackfeet Tribe of Indians, 471 U.S. 759 (1985) (tribe subject to state taxation only upon clear showing of congressional intent).

303. Cotton Petroleum Corp. v. New Mexico, 109 S. Ct. 1698, 1724-25 (1989) (Blackmun, J., dissenting).

304. Ohphant v. Suquamish Indian Tribe, 435 U.S. 191, 210-11 (1978) (quoting portions of Crow Dog, 109 U.S. at 571, discussed at supra note 284).

305. Id. at 211. 
statutory language and legislative intent, support Oliphant only weakly. ${ }^{306}$ The dual notion of political community and civil rights is the strongest rationale for the Court's decision. Like Menominee Tribe and Solem, Oliphant is also consistent with a concern for the practical realities of political comnunity; as a result of the obsolescent allotment policy, only about fifty of the 3,000 residents of the reservation were nembers of the tribe. ${ }^{307}$ Indeed, it is precisely these practical realities that give credence to the civil rights concern.

The Court recently decided a case that brought together all the strands of political community and civil rights identified above. In Brendale v. Confederated Tribes and Bands of Yakima Indian Nation, ${ }^{308}$ a tribe sought to zone land within the reservation that was owned in fee simple by non-Indians. From the tribe's perspective, the ability to impose uniform land use regulation throughout its territory is at the heart of its sovereiguty. But such tribal regulations create civil rights problenis along the lines of Oliphant for the non-Indian fee holders. As in niany of the cases discussed previously, the problen resulted from the present effects of the General Allotnient Act, which led to an influx of non-Indian fee holders on that reservation.

The attempt to resolve the issue in Brendale splintered the Court. Justice White, jomed by Chief Justice Rehnquist and Justices Scalia and Kennedy, concluded that the tribe had no regulatory power over any non-Indian fee lands. ${ }^{309}$ For these Justices, the allotnient process had impliedly repealed the tribe's treaty-based autlority to regulate land use throughout the reservation. Nor did the tribe's inherent sovereignty, independent of the treaty, permit such regulation; it governs only internal tribal matters and relations with nonmembers who consent to the tribe's authority through conduct sucli as commercial transactions. Justice White did conclude that the tribe had a cognizable interest in being free fron1 activities on non-Indian fee land that "imperil the political integrity, economic security or the health and welfare of the tribe." 310 Although a creature of federal law, this right would be enforceable only by asserting it to local zoning authorities, whose decision would then be subject to challenge in state or federal court. ${ }^{311}$

Thus, four Justices believed that the county, not the tribe, was the

306. See supra text accompanying notes 140-59.

307. Oliphant, 435 U.S. at 193 n.1. The Court did not go beyond noting the demographics, but a reader of the opinion cannot help but suspect that they powerfully influenced the way the Court viewed the case; see also infra note 466.

308. 109 S. Ct. 2994 (1989).

309. Id. at 2999-3009 (White, J., concurring in part and dissenting in part).

310. Id. at 3008.

311. Id. 
correct political community to zone non-Indian fee lands on allotted reservations. According to this view, tribal sovereignty has no geographical component. The tribal political community is nierely an aggregation of menibers who as "neighbors often have a protectable interest in what is occurring on adjoining property." ${ }^{312}$ Non-Indian fee holders, as persons outside that political community, are subject to its regulation only by consent.

Justice Blackmun, joined by Justices Brennan and Marshall, took a dianietrically opposite approach. He assumed that, absent word from Congress, inherent tribal sovereignty was geographical in nature and survived except when inconsistent with overriding national imterests. ${ }^{313}$ Inherent sovereignty allowed the tribe to zone non-Indian fee lands when activities there iniplicate a significant tribal interest. These Justices stressed that, since the tribe concededly had exclusive jurisdiction to zone Indian land on the reservation, the tribe was the only sovereign that could establish a comprehensive zoning plan. The Justices also asserted that "[t]his fundamental sovereign power of local governments to control land use is especially vital to Indians, who enjoy a unique historical and cultural connection to the land." ${ }^{314}$ For these Justices, the tribal political coniniunity extended beyond a menibership hist to include significant aspects of geography, and apparently the civil rights of the non-Indian fee holders were deenied less important than those of criminal defendants, ${ }^{315}$ which had tipped the balance the other way in Oliphant.

The swing votes in Brendale-Justices Stevens and O'Connor, in an opinion by Justice Stevens-approached the definition of the Indian political coinmunity at a more concrete level. ${ }^{316}$ For thein, a tribe's presuniptive authority to exclude noninembers from the tribe's territory necessarily included the lesser power to regulate land use throughout that territory. The Justices defined the issue as whether the tribe's "virtually absolute power to exclude has been either diminished by federal statute or voluntarily surrendered by the Tribe itself." ${ }^{317}$ Concluding that the General Allotment Act provided no clear guidance, Justice Stevens attenipted to find a solution consistent both witl the circumstances of the case and the probable expectations of Congress had it considered the issue.

Justice Stevens wrote that "just as Congress could not possibly have intended in enacting the [General Allotment] Act that tribes would

312. Id.

313. Id. at 3017-27 (Blackmun, J., concurring in part and dissenting in part).

314. Id. at 3022 .

315. Id. at 3020 (asserting that civil jurisdiction has always been part of Indian tribal sovereignty).

316. Id. at 3009-17 (Stevens, J.).

317. Id. at 3009 . 
maintain the power to exclude bona fide purchasers of reservation land from that property, it could not have intended that tribes would lose control over the character of their reservations upon the sale of a few, relatively small parcels of land."318 Thus, for Stevens and O'Connorbut not for any of the other Justices-it became critical to examine the reservation in detail. One area of the reservation had traditionally been closed to the general public, and the other area had not been similarly restricted since $1954 .{ }^{319}$ In Brendale, two portions of non-Indian fee land were at issue, one in the opened area, the other in the closed area. As the Court had done in Solem, the reservation dimimishment case, ${ }^{320}$ Justice Stevens stressed the contrasting circumstances of the two areas and concluded that the tribe could zone non-Indian fee lands in the closed, but not the opened, area. ${ }^{321}$

Brendale is an incoherent smorgasbord of concerns about political community and civil rights. Four Justices took a narrow view of the tribal political community and an expansive view of non-Indian civil rights; three Justices adopted precisely the opposite presumptions; and two Justices avoided broad rules of law and focused on the facts. As in our earher discussion of the values of avoiding obsolescence, using manageable judicial standards, and preserving Indian rights from inadvertent loss, we conclude this discussion of the values of civil rights and political community with a serious problem: Is there a way to aggregate the Court's decisions into some understandable construct? Or is federal Indian law a hopeless muddle? Further consideration of these matters requires an extended discussion of the conflicting nature of the important factors in the cases we have exammed.

318. Id. at 3014 .

319. While the case was pending, the closed area became more "open": the Bureau of Indian Affairs reopened roads in this area to the public. Id. at 3000 n.2. For convenience, I will continue to refer to this as the closed area.

320. See supra text accompanying notes 66-77.

321. Less than $1 \%$ of the land in the closed area (excluding land owned by lumber companies) was owned in fee. Traditionally, the tribe had limited entry into the closed area only to its members, to those with property or business interests there, and to short-term recreational users. The tribe had maintained this area for timbering, the major source of tribal revenue, and for the preservation of pristine areas, which provided a cultural and religious refuge. The fee land at issue in this area was, in fact, in the heart of the closed region and had been inherited by its owner from his mother, who had been a member of the tribe. In these circumstances, Justice Stevens concluded that the tribe retained the capacity, and thus the authority, to zone this non-Indian fee land. Brendale, $109 \mathrm{~S}$. Ct. at 3012-15. In the opened area, by contrast, Indians constituted less than $20 \%$ of the population, almost half the land was owned in fee, much of the land that remained Indian-owned had bcen leased to non-Indians, and the county was providing significant public services. Justice Stevens thought that the tribe had neither the capacity nor any special interest in exercising zoning authority over fee lands in this opened area. Id. at 3015-17. Thus, the other non-Indian land at issue in the case, which was located in the opened area, was beyond tribal regulatory power. Id. at 3012-17. 


\section{Uniformity and Formalism, Uniqueness and Contextualism}

All public law suffers from an inherent tension between formal rules and justice im individual cases. Part $I$ has suggested that formalism im interpretation, under which congressional expectations should control judicial construction, has not governed many important federal Indian law cases. Thus far in Part II, we have examined a variety of factors that coalesced in these cases in an eclectic fashion. Some of tle factors are dynamic, suclı as abandoning obsolescent congressional intent. Other factors are more static, sucll as preserving Indian riglits and the Indian pohitical commumity. Still otliers seem almost completely contextual: determining whether an Indian political commumity exists, developing manageable judicial standards, and protecting civil rights. At base, all the cases concern the degree to which Indian tribes and their members have a legally protected interest in umiqueness, or must have their claims treated uniformly witl those of non-Indians. The cases decided im the 1988 Term-Brendale (the zoning case), Cotton Petroleum (the state tax case involving a non-Indian 'tribal contractor), and Holyfield (the adoption case)-illustrate the problem well.

As Brendale suggests, the current Court is sharply divided on low to approach federal Indian law. Justices Marshall and Blackmun approacl Indian cases with a strong presuinption in favor of Indian umqueness, as did now-retired Justice Brennan. ${ }^{322}$ Another set of Justices, exemplified by Justice White's opimion in Brendale, defines the Indian political commumity narrowly. These Justices generally subject tribes to the same legal rules applicable to others. ${ }^{323}$ Occasionally, some Justices atteinpt to mediate the tension between uniformity and uniqueness by letting the context of the case govern the outcome, as Justices Stevens and O'Connor did im Brendale. Customarily, lowever, as Cotton Petroleum shows, Justice Stevens is a leader of the group for whom Justice White wrote in Brendale. ${ }^{324}$

Where a majority of Justices uses no colierent methodology, it is not

322. Indeed, Justice Brennan voted for the Indian interest in every case in which he participated that is discussed thus far in the text of this Article, and Justice Marshall voted against the Indian interest only when it ran up against the value of using manageable judicial standards in Mitchell $I$. In addition to joining Justice Marshall in Mitchell I, Justice Blackmun voted against the Indian interest only in Oliphant, where there were serious cross-cutting civil rights concerns.

323. Justice Rehnquist (now Chief Justice) epitomizes this position. Except for Martinez, where concern for manageable judicial standards perhaps influenced him, he voted against Indian interests in every non-unanimous case in which he participated that is mentioned thus far in the text of this Article.

324. Justice Stevens voted against Indian interests in every case in which he participated that is mentioned thus far in the text of this Article except for the Mitchell cases (where one might speculate that the normative attractiveness of allowing recovery held sway), Martinez (where perhaps manageable judicial standards controlled), and to some extent Brendale. 
surprising that incoherent cases like Brendale result. Moreover, in particular cases inore formal sources of legal interpretation will move some Justices froin one camp to another. In Holyfield, for example, Justices White, O'Connor, and Scalia jomed Justices Brennan, Marshall, and Blackmun in concluding that the tribal court had exclusive jurisdiction to resolve the Indian child adoption issue. The statutory language, which supported this result, ${ }^{325}$ probably swayed Justice Scalia, the leading textualist on the Court. ${ }^{326}$ In addition, the legislative history of the Act supported the outcome as well. ${ }^{327}$ This probably convinced Justices White and $O^{\prime}$ Connor, who are attracted to intentionalist interpretation. ${ }^{328}$ These factors were absent in Cotton Petroleum, where Justices White, O'Connor, and Scahia jomed Justice Stevens in holding that the non-Indian lessee-and, im effect, the tribe-were subject to state oil and gas production taxes.

In addition to the impact of overall presumptions about uniqueness or uniformity and the pull of formal sources of meaming in the case under review, the lesson to be drawn from Part II is that the Court will consider a variety of less formal factors in deciding Indian law cases. These factors include the availability of manageable judicial standards, the potential obsolescence of legislative intent, and the role of political community and civil rights. In a case hike Brendale, these factors not only fail to mandate any particular outcome, they are in great tension.

As to manageable judicial standards, even fairly formal rules such as those adopted by Justices White and Blackmun in Brendale leave substantial room for judicial development. ${ }^{329}$ Justice Stevens' contextual mquiry in Brendale imvites case-by-case litigation, for it asks whether in context a tribe has a significant interest in inposing, and the capacity to impose, comprehensive land use requirements. The knotty problem in Brendale results from the obsolete pohicy of allotment, but unfortunately

325. The key statutory term in Holyfield was "domicile," which the statute did not define. The majority opinion gave the term its generally accepted meaning in American law. Band of Choctaw Indians v. Holyfield, 109 S. Ct. 1597, 1605-08 (1989).

326. See infra note 361 and accompanying text.

327. See Holyfield, $109 \mathrm{~S}$. Ct. at 1599-1602, 1609-11 (legislative history discussion).

328. See, e.g., Saint Francis College v. Al-Khazraji, 481 U.S. 604 (1987) (White, J.) (42 U.S.C. $\S 1981$ (1982), which provides that all persons shall have certain rights equivalent to those "enjoyed by white citizens," must be interpreted in light of the definition of Caucasian that the enacting Congress understood, not our contemporary definition); Commissioner v. Engle, 464 U.S. 206, 214 (1984) (O'Connor, J.) ("sole task" of Court in statutory interpretation is to determine congressional intent).

329. White's Brendale opinion ascribes to tribes a federal right (enforceable in local zoning proceedings) to be free from uses of non-Indian fee land that "imperil the political integrity, economic security or the health and welfare of the tribe." Brendale v. Confederated Tribes \& Bands of Yakima Indian Nation, 109 S.Ct. 2994, 3008 (1989). Under Blackmun's view, the tribe could "exercise civil jurisdiction over non-Indian activities on tribal reservations where those activities ... implicate a significant tribal interest." Id. at 3018. 
no contemporary solution has successfully garnered a majority of the Court. No majority is willing to hold either that a tribe has zoning authority over the entire span of an allotted reservation regardless of other facts, or that non-Indian fee holders always have the right to be free from regulation by a sovereign-the tribe--about whose decisions they have no formal political say.

In the final analysis, the cases do not suggest any presumptive hierarchy for the values identified in this Part that affect judicial decisionmaking. Tribal sovereignty (the value of uniqueness) is much ballyhooed, but it nonetheless often yields to the value of uniformity. Although the great bulk of the Court's opinions interpreting statutes does suggest some general way to model statutory imterpretation, ${ }^{330}$ the Indian law cases seem too normatively diverse and too fact-bound to accommodate even some simple model of legal inquiry. It is easy to reject imtentionalism as a model, and it is possible to identify a variety of important factors that have trumped intentionalist values in particular cases. Nevertheless, it seems impossible to arrange those values in a way that consistently describes how the Court has proceeded when these values conflict. Although one or more of the factors explam each case we have examined, collectively the factors are so deeply divisive that they seemingly add up to nothing. Moreover, the prospects for developing a priority among these factors is inade all the inore difficult by the Court's repeated failures even to identify them, inuch less candidly evaluate their significance.

It seems time, therefore, to turn more fully to the role of theory in federal Indian law. How should one accommodate the cross-cutting currents of uniformity and uniqueness, of formalism and contextualism, that seem to influence federal Indian law so powerfully but so incoherently? Rather than propose general rules, Part III will suggest a different approach to Indian law problems that seeks to retrieve what is useful from these cross-currents and to identify what leads us astray. If we can sharpen the way we think about Indian law problems and accept some cases as paradigms for right decisions, we may be able to build a better approach for this area. But Parts I and II also lead to skepticism about the judicial capacity to resolve federal Indian law disputes. We need to evaluate the potential roles Congress can play as well. These inquiries require that we first assess and then consider alternatives to the formalist approaches now dominating federal Indian law theory.

330. See generally Eskridge \& Frickey, supra note 22. 


\section{III}

The Court, the Congress, AND the Tribes: Away

From a General TheOry of Federal INDIAN LAW ${ }^{331}$

Since the 1942 publication of Felix Cohen's Handbook of Federal Indian Law, ${ }^{332}$ the first general treatment of this field, most scholars have followed Cohen's example of promoting basic concepts that preserve tribal sovereignty while accommodating the modern American state. ${ }^{333}$ For most, the Court deserves generally high marks in protecting tribal rights from erosion, while Congress is the federal institution unost worthy of fear from the Indian perspective. The apotheosis of this Indian law faith is Charles Wilkinson's recent book, American Indians, Time and the Law, in which he seeks to identify "a principled and coinprehensive set of justifications for the field of Indian law."334 Wilkinson concludes that the Court's "decisions generally have been principled, even courageous." 335 The 1982 edition of the Handbook of Federal Indian $\mathrm{Law}^{336}$ is a compilation of the Court's doctrines that is syinpathetic to this faith.

Recently, however, a few scholars have taken a critical turn. ${ }^{337}$ They have suggested that the Court's performance in federal Indian law has been confused and imconsistent. ${ }^{338}$ More generally, some critics have attacked the Court's basic approaches, such as the trust relationship. ${ }^{339}$ Probably the most significant attack has been leveled at the plenary power doctrime. Critics argue that this doctrime lacks a constitutional

331. With apologies to Shiffrin, The First Amendment and Economic Regulation: Away from a General Theory of the First Amendment, 78 Nw. U.L. REV. 1212, 1255 (1984).

332. See F. COHEN, HandBooK of Federal Indian LAW (1942).

333. A useful bibliography is Fausett \& Royster, Courts and Indians: Sixty-Five Years of Legal Analysis: Bibliography of Periodical Articles Relating to Native American Law, 1922-1986, 7 LEGAL REFERENCE SERVS. Q. 107 (1987).

334. C. WILKINSON, supra note 6 , at 3.

335. Id. at 4.

336. See HANDBOOK OF INDIAN LAW, supra note 7.

337. A pathbreaking critique is R. BARSH \& J. HENDERSON, THE ROAD: INDIAN TRIBES AND Political LiberTy (1980). In addition, see the materials in CoMm. on NATIVe AMerican Struggles, National Lawyers Guild, Rethinking Indian Law (1982). These two books are the precursors of the introduction of the Critical Legal Studies perspective to federal Indian law.

338. See, e.g., Barsh, The Omen: Three Affiliated Tribes v. Moe and the Future of Tribal SelfGovernment, 5 AM. INDiAN L. Rev. 1, 1 (1977); Clinton, State Power over Indian Reservations: A Critical Comment on Burger Court Doctrine, 26 S.D.L. Rev. 434, $439-40$ (1981); Pelcyger, Justices and Indians: Back to Basics, 62 OR. L. Rev. 29, 30 (1983).

339. See Note, Rethinking the Trust Doctrine in Federal Indian Law, 98 HARV. L. REv. 422 (1984). 
basis, since the only express constitutional grant of legislative power concerning Indians merely provides Congress the authority to regulate commerce with the tribes. ${ }^{340}$ The absence of any general power to regulate tribes or individual Indians, ${ }^{341}$ coupled with an interpretation of the Indian commerce clause limiting it to commercial relations between tribes and non-Indians, ${ }^{342}$ invalidates many federal, and all state, intrusions upon tribal affairs. Moreover, the plenary power doctrine is inconsistent with the normative vision of the Bill of Rights and the fourteenth amendment, ${ }^{343}$ as well as with emerging principles of international human rights. ${ }^{344}$

A defender of the Indian law faith might respond ${ }^{345}$ that the critics have some good theoretical arguments, but have failed to sway the Justices, who continue to assume the validity of the plenary power doctrine and other longstanding approaches. Moreover, the Court, part of the government itself, can hardly be expected unilaterally to rid American society of the present effects of colonization, the very root of the government's power. Nonetheless, the Court has made practical judginents that soften the harshness of colonization: it has centralized power in Congress, not in the state legislatures (where local passions would be more prejudicial to Indians); through the use of canons, it has enforced only grudgingly congressional intentions to undermine tribes; and it has created a trust relationship that affords some protection against misconduct by the federal executive branch.

The emergence of this debate may be the most exciting development in the history of scholarship in federal Indian law. ${ }^{346}$ Nonetheless, it is

340. See supra note 8 and accompanying text.

341. See Ball, Constitution, Court, Indian Tribes, 1987 AM. B. Found. Res. J. 1, 46-55.

342. See Clinton, Isolated in Their Own Country: A Defense of Federal Protection of Indian' Autonomy and Self-Government, 33 STAN. L. REv. 979, 991-1001 (1981).

343. See Newton, supra note 10, at 241-88 (applying modern constitutional doctrine to tribal sovereignty and property conccptions).

344. See, e.g., Barsh, Indigenous Peoples: An Emerging Object of International Law, 80 AM. J. INT'L L. 369 (1986); Williams, The Algebra of Federal Indian Law: The Hard Trail of Decolonizing and Americanizing the White Man's Indian Jurisprudence, 1986 WIS. L. REv. 219; Conment, Toward Consent and Cooperation: Reconsidering the Political Status of Indian Nations, 22 HARv. C.R.-C.L. L. REv. 507 (1987) (authored by Rachel San Kronowitz, Joanne Lichtınan, Steven Paul McSloy \& Matthew G. Olsen).

345. See generally Collins, Indian Consent to American Government, 31 ARIZ. L. REV. 365 (1989), for a thoughtful response to the critical challenge.

346. Many scholars would disagree and cite the publication of Felix Cohen's treatise in 1942 as the most exciting development in the field. To be sure, Cohen did a remarkably good job of inposing coherence upon the untidy world of federal Indian law, as well as providing an invaluable source for research. But the very dominance of Cohen's treatise and of his modern day successors raises questions about whether federal Indian law scholarship fosters sufficient diversity of perspectives. The emergence of a contrary set of critics not only demonstrates new vigor in the field, but it also may prod the traditionalists to defend their positions. 
striking that both sets of contestants are often engaged in highly conceptual attempts to cabin judicial and legislative discretion by formal theory. Most scholars on both sides have considered the appropriate approach to theory to be "foundational" in nature: the theorist must identify the value or concept that can provide, through deductive reasoning, objectively right answers in the cases.

For defenders of the faith, these elemental concepts include congressional plenary power, inherent tribal sovereignty to the extent not formally annulled, the federal-tribal trust relationship, and Worcester's ban on state regnlation in Indian country. If appled mechanically, these concepts control discrete controversies. As for the first, Congress can do about anything it wishes. ${ }^{347}$ For modern purposes, the tribe is fully sovereign except to the extent a federal statute, agreement, or treaty says otherwise. ${ }^{348}$ The federal executive branch owes fiduciary duties to tribes, and states have no role in Indian country without congressional authorization. For critics, the correct approach to Congress' constitutionally enumerated powers invalidates the plenary power doctrine. Moreover, harmful distinctions involving Indians violate the Bill of Rights, and norms of international human rights should control treatment of Indians. On both sides of the argument, accepting the premise leads directly to the conclusion.

It is clear from Parts I and II, however, that foundational theorylike an intentionalist approach to statutory interpretation-is an unlikely candidate for resolving particular disputes in federal Indian law. In these cases, no single value is privileged, and the several values involved are too complex and cross-cutting, the facts of the cases too uneven, and the strands of doctrine too tenuous to aggregate into a foundational theory that can control future cases. ${ }^{349}$

The defenders of the faith are probably correct that the Court is unlikely to use any foundational theory to abandon the plenary power

347. The takings clause provides compensation for some congressional extractions of Indian property. See United States v. Sioux Nation of Indians, 448 U.S. 371, 407-24 (1980) (upholding Court of Claims finding that 1877 Act taking the Black Hills failed to provide fair equivalent value for lands, thus constituting a taking requiring just compeusation).

348. The only exceptions to this concept of tribal sovereignty would involve a limited loss of sovereignty that Chief Justice Marshall found, based on the original circumstances of colonization. See Worcester v. Georgia, 31 U.S. (6 Pet.) 515, 559 (1832) (tribes required to have exclusive government-to-government relationship with the European sovereign that "discovered" their regions); Johnson v. McIntosh, 21 U.S. (8 Wheat.) 543 (1823) (frequently interpreted as requiring tribes to engage in land transactions only with federal government).

349. For agreement on this proposition and an insightful discussion of the consequences of stuffing the unruly substance of federal Indian law into a few ill-fitting concepts, see Deloria, Laws Founded in Justice and Humanity: Reflections on the Content and Character of Federal Indian Law, 31 ARIZ. L. REV. 203 (1989). 
doctrine. But a leap of faith in their direction is nonetheless questionable. Sometimes the defenders' work seems too willing to call the glass half full rather than half empty, to attempt to gloss over a bad situation to win the next case. That approach belongs more to the advocate than to the scholar; it lacks the detachment and curiosity that ought to mark the boundary between lawyers promoting the interests of chents and scholars probing a field of law. ${ }^{350}$

If defenders of the faith successfully persuaded the Court to preserve what remains of tribal autonomy, the strategy would at least have the virtue of effectiveness. But, as Brendale (the zoning case) and Cotton Petroleum (the non-Indian contractor state tax case) inost recently indicate, today's Court finds hittle difficulty in avoiding the defenders' conceptual arguments and continumg the erosion of tribal independence. For example, writing just before Brendale, Richard Collins suggested that because the plenary power doctrine enables Congress to redress any abusive exercise of tribal power over nonineinbers, the principle that government decisions should be traceable to the "consent of the governed" actually supported allowing tribes to exercise geographical sovereignty over Indian country, including over nonmember fee land as in Brendale. ${ }^{351}$ My complaint is not that this is a poor argument, but that it ultimately has a doubly harmful effect upon tribal autonoiny: not only has the argument been unavailing, as Brendale shows, but it simultaneously re-ratifies the notion of plenary power.

I want to encourage a different, nonfoundationalist way of thinking about federal Indian law based upon recent scholarship on practical reasoning in law. Although this inquiry includes both critical and positive aspects, it assumes neither that federal Indian law inerits only vilification nor that the conceptualizations of Felix Cohen and his successors are the best ways to proceed. The critical impulse behind my inquiry is directed at the hardened conceptualisin of so much current scholarship in the face of the incoherence revealed in Parts I and II. ${ }^{352} I$ hope that a different

350. For a somewhat more extended discussion of the tension between scholarship and advocacy in federal Indian law literature, see Frickey, supra note 30, at 1207-15.

351. Collins wrote that under the plenary power doctrine "[t]he federal government, a government whose political support overwhelmingly favors the values of the non-Indian residents over those of their tribal hosts, provides an avenue of relief if tribal power over non-Indians becomes truly oppressive. Thus, plenary power gives democratic legitimacy to tribal jurisdiction over nonIndians." Collins, supra note 345 , at 386 . For a similar argument, see C. WiLkINSON, supra note 5 , at $117-18$.

352. Vine Deloria, Jr. has stated that " 'the Fallacy of Misplaced Concreteness'-the tendency to mistake the abstract for the concrete, the shift toward reification of concepts which depend for their validity on their ability to communicate observed facts"-is, unfortunately, "the hallmark of federal Indian law." Deloria, supra note 349, at 204. I agree, though no doubt some scholars in the field will think that this drastically overstates the case, or perhaps even fundamentally mistakes what the nature of legal scholarship should be.

I do not mean to suggest that every prominent scholar in federal Indian law always hews too 
inquiry might suggest ways of reconstructing federal Indian law to illuminate and to mediate this incoherence, and to face the concrete consequences of colonization in a inodern society.

My earlier work witl Daniel Farber ${ }^{353}$ and William Eskridge ${ }^{354}$ has suggested an approach we called "practical reason." This theory attacks legal problems froin a contextual framework-froin the ground up rather than by a descending inquiry from conceptual, formal theory. ${ }^{355}$ Although difficult to define, practical reason includes "a concern for history and context; a desire to avoid abstracting away the luunan component in judicial decisionmaking; an appreciation of the complexity of life; some faith in dialogue and deliberation; a tolerance of ambiguity, accommodation, and tentativeness, but a skepticisin of rigid dichotomies; and an overall lumility."356

Under this approach, the interpreter consults all potentially relevant sources of statutory meaning. These sources include statutory text, legislative expectations, statutory purposes, evolution of the statute over time, and coherence of the statute witl the broader public law. The interpreter will necessarily undertake this task with the preunderstandings resulting froin her own situation and experiences. For American judges and attorneys, inany of these preunderstandings consist of values shared in the American legal interpretive community-what inight be called that cominunity's web of beliefs. The interpreter's task is to approach the statute witl an open mind that constantly reevaluates her preconceptions, as well as all potential interpretations, in light of all sources of meaning. ${ }^{357}$

much to the foundationalist line. For suggestions urging more attention to context from an important scholar, see Clinton, Reservation Specificity and Indian Adjudication: An Essay on the Importance of Limited Contextualism in Indian Law, 8 HAMLINE L. REV. 543 (1985).

353. See Farber \& Frickey, Practical Reason and the First Amendment, 34 UCLA L. REv. 1615

(1987). Farber has returned to the inquiry in Farber, Legal Pragmatism and the Constitution, 72 MiNN. L. REv. 1331 (1988).

354. See Eskridge \& Frickey, supra note 22. Eskridge more fully evaluates the hermeneutical aspects of this inquiry in Eskridge, Gadamer/Statutory Interpretation, 90 Colum. L. REV. 609 (1990).

355. For citation to other legal scholarship adopting related approaches, see Farber \& Frickey, supra note 353, at 1645 n.129. More recent contributions include R. POSNER, THE Problems OF JuRisprudence (1990); Burton, Law as Practical Reason, 62 S. CAL. L. Rev. 747 (1989); Posner, The Jurisprudence of Skepticism, $86 \mathrm{MiCH}$. L. REV. 827 (1988). A link to feminist theory is developed in Bartlett, Feminist Legal Methods, 103 HARv. L. REv. 829, 849-63 (1990). For criticism of the overall approach from very different perspectives, see Hutchinson, The Three " $R$ ' $s$ ": Reading/Rorty/Radically (Book Review), 103 HARv. L. REV. 555 (1989); Schauer, Harry Kalven and the Perils of Particularism (Book Review), 56 U. CHI. L. REv. 397 (1989); Schlag, Missing Pieces: A Cognitive Approach to Law, 67 TEx. L. REV. 1195, 1223-25 (1989). For an assessment by a prominent critical scholar of the possibilities and pitfalls of pragmatism in federal Indian law, see Singer, Property and Coercion in Federal Indian Law: The Conflict Between Critical and Complacent Pragmatism, 63 S. CAL. L. ReV. 1201 (1990).

356. Farber \& Frickey, supra note 353, at 1646.

357. See Eskridge \& Frickey, supra note 22, at 352:

Because we always approach texts from the perspective of our own historically situated 
The interpretation that eventually results is likely to be the product of a congeries of supporting, interactive arguments, rather than a single deductive conclusion from one source of meaning. In this way, statutory "construction" takes on a somewhat literal ineaning and often consists of supporting arguments working like the "legs of a chair and unlike the links of a chain." "358

The importance of this model is not merely to rebut the notion that interpretation is mechamical or controlled by some foundationalist theory like intentionalism. One significant consequence of thinking about interpretation in this way is that statutes have a dynamic quality; they can mean different things over time and across contexts and interpreters. Thus, judges are not limited to static sources of statutory meaning, such as the statutory text, the context in which the statute was adopted, or the expectations of the legislature that enacted it. Judges should also consult post-enactment sources of meaning to attribute a functional ineaning to the statute in the context of current litigation. Such sources can include consideration of how the statute has evolved over timie, the nature of current values in the public law, institutional factors such as the goal of developing manageable judicial standards, and coherence with the current legal landscape in general. Another important result of the model is that criticizing a judicial interpretation mvolves not the assertion that the Court was wrong in some absolute sense, but that the Court failed to exercise practical reasoning and did not reach the interpretation that a full consideration of the problem should suggest to American-trained judges.

The very antiformalism of practical reasoning makes it impossible to break it down into discrete eleinents and summarize precisely how it operates. Nonetheless, some core attributes can be apphed to federal Indian law. The remainder of this Part seeks to identify some inquiries that arise if federal Indian law is subjected to "practical legal studies."359

horizon, we tend to project our 'preunderstandings' onto the text, viewed as a whole. That is essential to interpretation, because the preunderstandings are conditioned by tradition and, hence, help us link our horizon with that of the text. But ... a true dialogue with the text requires the interpreter to reconsider her preunderstandings as she considers the specific evidence in the case, and then to formulate a new understanding, which in turn is subject to reconsideration.

358. Farber \& Frickey, supra note 353, at 1644 (quoting R. SUMmers, INSTRUMENTALISM AND AMERICAN LEGAL THEORY 156 (1982)). For a more elaborate examination of this perspective on interpretation, see infra text accompanying notes 383-435.

359. Jay Feinman coined this term and developed some interesting potential connections between it and critical legal studies. See Feinman, Practical Legal Studies and Critical Legal Studies, 87 MICH. L. REv. 724 (1988); see also Eskridge, supra note 354 (evaluating Gadamerian hermeneutics against critical legal challenges); Singer, supra note 355 (assessing critical and complacent pragmatism). Feinman has returned to the topic and undertaken work on examining the nature and roles of paradigms in legal reasoning. See Feinman, The Jurisprudence of Classification, 41 STAN. L. Rev. 661 (1989). 


\section{A. Intentionalism in Federal Indian Law}

Practical legal reasoning rejects foundational theories of law-theories that begin with some first principle and attempt to resolve all cases by reasoning deductively from it. Instead, practical reasoning assunies that the world of facts and law is too unruly, and our values too complex and divisive, to allow foundational theory to control when it matters most-when it leads to a result that strikes judges as simply unacceptable in context. Accordingly, a practitioner of practical reason would reject any suggestion that the incoherence described in Parts I and II should be remedied by adopting nitentionalism as the foundational niethodology for federal Indian law cases.

But even those unwilling to embrace antiformalism unreservedly should question whether the Court's performance in federal Indian law would be improved through a rigid intentionalist approach. The literature on the faults of intentionalisn as foundational interpretive niethodology is now rich, ${ }^{360}$ and for our purposes a short review should suffice.

Some broad empirical and normative concerns undermine intentionalism as foundational theory. How can a large, diverse, bicameral Congress have a discermible "imtent" on narrow issues that arise later in litigation? Even if Congress did, how often will such an intent correspond to the President's understanding when he signed the bill into law? Since such actual intent seems so unlikely, courts must construct intent from legislative documentary sources, such as committee reports, statements made during congressional debate, and comments offered at hearings. How reliable are these materials? Is it likely that they accurately reflect the intentions of the persons responsible for them, who, in any event, may not have carefully considered the problems arising under the statute? Could some comments have been made strategically to skew later judicial interpretation? Are not powerful interest groups the niost likely to have access to legislators and staff members for skewing legislative history? For some of these and other reasons, even one current member of the Supreme Court, Justice Scalia, has argued against intentionalism in statutory interpretation. ${ }^{361}$

I would not abandon consideration of legislative intent. Legislative expectations have a normative salience in a democracy, and in many cases they may reflect a thoughtful attempt to promote public values. Moreover, some critics overestimate the difficulty of discerning original legislative expectations, as well as the frequency with which legislative

360. See sources cited supra note 22.

361. For general evaluations of intentionalism, with citations to Justice Scalia's many attacks upon it, see Eskridge, The New Textualism, 37 UCLA L. REv. 621 (1990); Farber \& Frickey, supra note 22, at 437-53; Zeppos, Legislative History and the Interpretation of Siatutes: Toward a FactFinding Model of Statutory Interpretation, 76 VA. L. REv. 1295 (1990). 
history is abused in ways that judges cannot identify and ameliorate. ${ }^{362}$ As a matter of overall statutory interpretation methodology, then, congressional expectations should be part of the equation. ${ }^{363}$ Nevertheless, relying upon legislative intent as the foundation for statutory interpretation is misguided, for both empirical and normative reasons.

As already suggested, a primary einpirical problem is that intentionalism requires asking a counter-factual and difficult question in many cases. It is unlikely that Congress ever anticipated, inuch less had some expectation about, the precise issue being litigated. In addition, enough surprising things happen in the legislative process to reduce our confidence about imaginatively reconstructing what probably would have happened on issues that never were directly confronted. ${ }^{364}$ Moreover, it seems unlikely, if not impossible, that judges can perform this historical inquiry-for which they have no formal training-without their own experiences and values influencing the process. ${ }^{365}$ Thus, intentionalism lacks the objectivity and predictability that are important selling points of any foundational theory.

To accept the proposition that even the discermible intentions of an adjourned legislature should control interpretation requires a normative theory of legislation that compels that conclusion. The constitutional separation of powers need hardly restrict the judiciary's powers so severely. ${ }^{366}$ In any event, a cross-cutting normative matter is the inappropriateness (for example, the absurdity, or impracticality, or disproportionate harshness) of intentionalist outcomes in some cases. Even relatively clear legislative expectations may have been uninformed, or proved wrong by developments arising after the enactment of the statute. In addition, imaginative reconstruction could result in giving politically powerful interest groups victories in the courts-after all, we would probably guess that had the issue come to a head, Congress would have tipped to the more powerful political factions-that they did not achieve in the legislative process. ${ }^{367}$

362. See Farber \& Frickey, supra note 22, at $437-53$ (critiquing the attack led by Justice Scalia on the consideration of legislative history as part of judicial interpretation).

363. See Eskridge \& Frickey, supra note 22, at 356-58 (suggesting the importance that judges place on considering Congress' original expectations).

364. For example, the prohibition on gender discrimination in employinent included in title VII of the Civil Rights Act of 1964 was strategically inserted as a floor amendinent by an opponent of the whole bill. See C. Whalen \& B. Whalen, The Longest Debate: A Legislative History of THE 1964 CIVIL RighTS ACT 115-17 (1985).

365. Indeed, even professional historians acknowledge that their own views influence their construction of history. See Eskridge, supra note 22, at 1510.

366. See id. at 1498-1511.

367. See Macey, Promoting Public-Regarding Legislation Through Statutory Interpretation: An Interest Group Model, 86 CoLUM. L. REv. 223 (1986) (suggesting a presumption that statutes promote the public good rather than the private interest). 
This general criticism of intentionalism as foundationalist theory is particularly telling in federal Indian law. As acknowledged in Bryan (the Public Law 280 tax case), the federal-tribal connection is an "ongoing relationship," not a one-shot legislative resolution of a narrow problein. To resolve today's controversies inechanically from Congress' probable expectations concerning, for example, the termination statutes and the allotment and surplus lands statutes would cause extraordinary hardship and difficult practical problems of implementation. Menominee Tribe (the termination case), Solem (the reservation diminishment case), and Mitchell (the allotinent mismanageinent sovereign immurity case) indicate the magnitude of such difficulties. In federal Indian law, a practical perspective calls upon judges to fuse the contemporary horizon with past congressional expectations, not to ignore the former in misguided allegiance to the latter. ${ }^{368}$

Even if legislative intentions are considered only one factor in statutory interpretation, however, they may be of such significance in a democracy that they should presuinptively control interpretation when they are clear. An assessment of the cases in light of any such nornu of legislative suprenacy must include at least three inquiries.

First, it becomes critical to define precisely what this norm entails. Daniel Farber's careful evaluation suggests that, even from a conventional perspective, the norm inerely requires judges not to disobey clear legislative orders. ${ }^{369}$ Even if this proposition is accepted, ${ }^{370}$ it begs the question of how to identify legislative signals that constitute "orders" (mandatory instructions for the context under hitigation) that are "clear." The Court did not disobey any clear legislative directives concerning the facts of any of our cases. In no case was there clear, specific statutory language or authoritative legislative history diametrically opposed to the Court's interpretation in the context before it. The only "clear" legislative intent in these cases emerged from general statutory language that fit the facts under litigation and from an imaginative reconstruction of what the enacting Congress would probably have said about the issue had it been forced to address it.

Menominee Tribe (the termination case) seems to come the closest to flouting clear legislative directives because the general statutory language easily captured the facts under litigation and there was legislative history "on point." ${ }^{371}$ But the legislative history involved-comments by

368. For elaboration, see infra text accompanying notes 384-85.

369. See Farber, supra note 22, at 283-94.

370. Cf. Eskridge, Spinning Legislative Supremacy, 78 GEo. L.J. 319 (1989) (questioning Farber's theory and arguing that the norm of legislative supremacy is less important than Farber suggests).

371. See supra text accompanying notes $55-57$. 
the tribe's counsel at a hearing, and the differences in various billsreveals neither widespread congressional consideration nor authoritative congressional intent. The statutory language generally supports a holding contrary to that in Menominee Tribe, but it says nothing in particular about treaty rights, inuch less hunting and fishing. Had the Termination Act or authoritative congressional committee reports stated that "all rights under all treaties are hereby abolished," the Court would almost surely liave gone the other way. Is it certain, however, that most members of even the Termination Era Congress would have thouglit it appropriate to shirk every single solemn treaty promise made to the tribe in one unilateral, general swoop?

There are a variety of normatively attractive reasons that might prompt us to ask the imaginative reconstruction question in Menominee Tribe by allowing the enacting Congress foresiglit into the future. ${ }^{372}$ These reasons include the evolving relationship between tribes and the federal government and the remarkable inability Congress lias shown to predict the direction of that evolution witl any accuracy. It inay seen clear what the 1953 Congress would have done had it squarely confronted the issue in Menominee Tribe. But what if the miaginative reconstruction question were prefaced as follows: "If the termination policy turns out to be a flop and is effectively abandoned by the executive brancl in short order, and if the Menominee suffer extraordinary hardship because of it, would you nonetlieless desire . . .?" It takes some uncliaritable assuinptions about Congress to be convinced that the Menominee lose under this form of miaginative reconstruction. It also takes a lighly strict approach to the separation of powers to consider this form of imaginative reconstruction inadmissible.

This analysis suggests a second inquiry for evaluating tle cases from the perspective of legislative supremacy-whether that norm can accommodate the consideration of post-enactinent developments. I find it impossible to think about Menominee Tribe, Solem, and Mitchell without considering the abject failure of the termination and allotment policies. Indeed, it is hard to forget that five years after the Menominee Tribe decision, Congress reinstated the tribe's federally recognized status, ${ }^{373}$ soinething that probably would have been inuch more difficult to do liad Menominee Tribe been decided differently. As explained below, one of the great insiglits of hermeneutics is that the interpreter camiot avoidindeed, slould not try to avoid-bringing her own conteinporary horizon to bear upon the interpretive problem. ${ }^{374}$ Froin that liorizon, I cannot be

372. See Eskridge \& Frickey, supra note 22, at 357-58.

373. See supra note 226.

374. See infra text accompanying note 386 . 
certain that the Court in Menominee Tribe disobeyed a clear legislative command.

Moreover, even relatively conventional statutory interpretation theory incorporates post-enactment developments in several important circumstances. For example, Daniel Farber and I have argued that, in all but crystal-clear cases of legislative intent, the interpreter should discount the strength of the probable legislative intent by the consequences of following it. ${ }^{375}$ In addition, Farber has suggested a version of statutory cy pres under which courts inay redirect statutory meaning when changed circumstances prevent the statute froin achieving the enacting legislature's goals. ${ }^{376}$ The previously examined cases do no violence to the norm of legislative supremacy when they sanction such modification. ${ }^{377}$ In addition, the Supreme Court's actual practice in statutory interpretation, for which Parts I and II provide evidence, reveals that in

375. We made this suggestion because "[r]ational decisionmaking under uncertainty requires that we take those consequences into account in choosing between risky alternatives." See Farber \& Frickey, supra note 22, at 462.

376. See Farber, supra note 22, at 310-14. As Farber explains, this approach is consistcnt with a realistic appraisal of legislative supreinacy because it promotes what a rational legislature would have chosen to do if it had considered the problem, and because it does not violate any specific legislative directive to the contrary. "Because the doctrine is one that rational legislators themselves would favor, courts that engage in this type of dynamic interpretation can propcrly claim to be impleinenting rather than frustrating the legislators' design." Id. at 310-11 (footnote omitted).

377. Cases like Solem and Mitchell involve clearly obsolete original legislative expectations concerning the allotment process, which was set in motion almost a century earlier. Although much less time had passed between the enactment of the statutes in question and the decisions in Menominee Tribe and Bryan, the original congressional expectations concerning the termination process and Public Law 280 were nonetheless clearly obsolete as well. Eskridge's theory of dynamic interpretation, see Eskridge, supra note 22, easily accoininodates these outcomes, but more conventional approaches work as well. Farber's cy pres analogy, see supra note 376 and accompanying text, seems wholly apposite. In addition, considering the Draconian ramifications of contrary interpretations in these cases, the notion of discounting probable legislative expectations by their consequences also seeins compatible with the outcomes in these cases. See supra text accompanying note 375 . The decisions also secm consistent with the model of statutory interpretation as practical reasoning proposed in Eskridge \& Frickey, supra note 22, undcr which legislative expectations are factored into statutory interpretation, but evolutive and other practical concerns can sometimes control nonctheless.

The hardest decision to square with relatively conventional notions of legislative suprcmacy is not Menominee Tribe, but Martinez. The rapid obsolescence of the termination policy supports the outcome in Menominee Tribe. In Martinez, by contrast, only a decade separated the cnactment of ICRA and the decision, and the policy of ICRA was no more inconsistent with the American public law tradition at the time of the decision than it was when ICRA was enacted. Nonetheless, Martinez did not violate a direct congressional comınand. The practical factors supporting Martinez, see supra text accompanying notes $243-47$, make the deeision supportable (but not obviously correct) under the Farber \& Frickey "discounting" theory and under the Eskridge \& Frickey practical reasoning model, if not under the Farber cy pres theory.

Froin the above, it is obvious that scholarship bearing my name has danced around the legislative supremacy norm in a variety of ways. At least in part, my meanderings are attributable both to my own ambivalence about the importance and reach of the norm and to the consequences of joint authorship (under which commentary tends to drift toward a median point somewhere between the somewhat conflicting views of joint authors). 
some important cases even more expansive evolutive and practical concerns have outweighed indications of original legislative expectations. ${ }^{378}$ Thus, dynamic interpretation im federal Indian law can claim important normative and einpirical support, even froin relatively conventional perspectives.

Third, the meaning of the legislative suprenacy norm in federal Indian law cannot be divorced froin the plenary power doctrine. In the usual case outside federal Indian law, the Constitution imposes significant side constraints upon legislative policy. Within those constraints, incorporating legislative expectations into the statutory interpretation calculus furthers our systein's respect for legislative authority without unduly fostermg legislative interference with personal liberty. ${ }^{379}$ Moreover, in the ordinary case, constitutional values not only provide rights to protect against legislative abuse, but they also establish background norms that inform the way judges approach interpreting the statute. ${ }^{380}$

In federal Indian law, there are usually no significant side constraints upon Congress. This judicial deference at the constitutional level could also have led to a tradition of absolute judicial fealty to original congressional expectations at the interpretative level. As Parts I and II demonstrate, however, quite the contrary has resulted. What the Court has given with one hand (plenary power) it has at times softened with the other (the canons). Protection of tribal interests from Anglo-American intrusion could, therefore, be considered an underenforced constitutional norm. ${ }^{381}$

Why, then, do the canons often seein so hollow, as in Cotton

378. See Eskridge \& Frickey, supra note 22, at $328-32,342-43,346-47,358-60,371-72$ (discussing United Steelworkers v. Weber, 443 U.S. 193 (1979)); id. at 343-45, 347-48, 358-60, 37172 (discussing Bob Jones Univ. v. United States, 461 U.S. 574 (1983)); id. at 372-75 (discussing Bryan v. Itasca County, 426 U.S. 373 (1976)). For a discussion of the tension between intentionalisn and evolutive values, see $i d$. at 378-84.

379. See Eskridge \& Frickey, supra note 22, at 356.

380. For elaboration, see Eskridge, supra note 221; Sunstein, supra note 221.

381. See Sager, Fair Measure: The Legal Status of Underenforced Constitutional Norms, 91 HARV. L. REV. 1212 (1978) (arguing that certain constitutionally based clainis, which are "underenforced" because of institutional concerns, are nonetheless legitimate). In this light, Hampton v. Mow Sun Wong, 426 U.S. 88 (1976), is particularly informative because it deals with federal discrimination against aliens, another class of persons over which Congress has plenary power. In Mow Sun Wong, the Court invalidated a century-old Civil Service Commission rule which prohibited the employnent of aliens in any federal civil service position. The Court assumed that the Congress and the President had the power to adopt the rule. Nevertheless, the Court concluded that the Civil Service Conımission had no legitimate interest in pronulgating the rule that outweighed the harm it caused. The very existence of plenary power in Mow Sun Wong seemingly led the Court to ensure that it was an appropriate entity operating within a current horizon that had exercised the power. Note also that, analogously to federal Indian law, there is a favorable canon of interpretation in federal inınigration cases "of construing any lingering ambiguities in deportation statutes in favor of the alien." INS v. Cardoza-Fonseca, 480 U.S. 421,449 (1987). For an excellent discussion of plenary power in inınigration law, see Motonura, Immigration Law After a Century of 
Petroleum $?^{382}$ From the perspective of practical reason, the best justifications for them-their correlative relationship to the plenary power doctrine, their connection to the American public law tradition, their sliorthand way of mediating the Anglo-American and Indian horizons, their notions about comparative institutional coinpetence-may not be apparent to judges and litigators. The next Section analyzes how a candid assessment of these factors might better address contemporary federal Indian law problems.

\section{B. Using Practical Reason to Reconsider Federal Indian Law}

The preceding discussion shows that conventional intentionalist interpretation fails to explain federal Indian law as a descriptive inatter and cannot be justified as a normative matter. As an alternative, practical legal reasoning is a better way of approaching the field. Practical legal reasoining describes what the Court lias done in statutory interpretation cases in general and in federal Indian law decisions in particular. Moreover, there are powerful normative reasons for preferring the eclectic approach of practical reason to foundational alternatives. Considering limitations of space and the complexity of a practical reasoning analysis, lowever, a full evaluation of federal Indian law from a practical, antiformalist perspective must await another day. Indeed, without more information, the global exploration demanded by practical reasoning cannot be fully undertaken for the cases discussed in Parts I and II. Nonetlieless, some useful and suggestive mquiries can be made at this tinne, beginning with a summary of the methodology and then an attempt at its application in federal Indian law.

\section{Practical Legal Reasoning: An Overview}

In addition to rejecting foundationalist theory, practical reason

Plenary Power: Phantom Constitutional Norms and Statutory Interpretation, 100 YALE L.J. 545 (forthcoming 1990).

In another sense, however, the analogy to aliens is inapposite, and federal Indian law takes on a different constitutional dimension. Aliens who enter the United States submit themselves to congressional power under the Constitntion. Tribes, in contrast, were sovereign groups before the Constitution was drafted. The Constitution, moreover, does not even purport to grant Congress anything other than the power to regulate commerce with them. It is difficult to demonstrate that tribes and their members have consented to their legal status. See generally Collins, supra note 345. Thus, many aspects of federal Indian law are "extra-constitutional" in nature and unilateral in character, which may help explain why the Supreme Court has sometimes exhibited solicitude to Indian grievances, often throngh the use of the canons. In addition to the obvious normative attractiveness of ameliorating some harshness in this manner, the callons help accommodate obsolescent congressional expectations both with the current situation (in which tribes remain sovereigus, despite the expectations of some long-adjoumed Congresses) and with our tradition of leaving tribes with some capacity of self-determination.

382. See supra text accompanying notes 262-64. 
includes a variety of positive aspects. ${ }^{383}$ For present purposes, three metaphors can be deployed to illuminate some of the central features of this theory: the web of beliefs in the legal interpretive community, the relative strengths of a cable and a chain, and the hermeneutical circle.

Practical reason assumes that interpretation, whether constitutional, statutory, or common law, has a situated nature, not an abstract one. It is rooted in the context of the case, as sculpted by the advocates. More generally, it is situated in the American legal interpretive community. It follows that legal interpretation is greatly influenced by the cluster of values-the web of behefs-shared in the legal interpretive community.

For advocates, the task is to engage in a contmuing conversation, comparing plausible interpretations against the web of behefs in the legal interpretative community. The conversation necessarily has a contextual orientation, as participants attenipt to solve the problem at hand rather than to construct foundationalist theory. Although suggested interpretations cannot be objectively vahidated, the eclectic method of practical reason suggests that some answers are better than others: they better match the context, they fit better with the legal community's web of beliefs, and they better accommodate the often competing factors found in our traditions. Argument tends to be cumulative rather than linear, for an argument that draws some support from several values resonating im the legal interpretive community will usually be stronger than one that follows deductively froin only one value. The metaphor of the cable and the chain is illuminating: a cable draws its strength from the cumulative effect of its inany strands, but a chain is ouly as strong as its weakest link.

The difficult task of the judge is to engage and to guide the advocates in this dialogue and, ultimately, to conclude the conversation. Under the hermeneutical perspective informing practical reason, judges inevitably bring their own horizon (their backgrounds, their values, their current context) to the interpretive project. They must, however, look beyond their own horizon and fuse the various horizons involved in the case, such as those of the court, the preunderstandings embodied in the text of any statute or other source of positive law involved, and the perspectives of the legislature that enacted any relevant positive law. ${ }^{384}$ An

383. Again, I will borrow, with only infrequent attribution, from Eskridge, supra note 354; Eskridge \& Frickey, supra note 22; Farber \& Frickey, supra note 353.

384. 'Interpretation involves the 'fusion of horizons,' the way in which the 'old and new are always combining into something of living value." " Eskridge, supra note 354, at 623 (quoting H.-G. GADAMER, TRUTH AND METHOD 306 (J. Weinsheimer \& D. Marshall trans. 2d rev. ed. 1989)). Eskridge, supra note 354 , at $621-24$, provides some general discussion of the fusion of horizons, and the remainder of his article incorporates the metaphor into both a general analysis of statutory interpretation and a consideration of a specific interpretive problem.

This is not the place for an extended description and assessment of hermeneutics. I am relying here upon Eskridge, supra note 354, who in turn assessed the work of Gadamer. Although I am not purporting to explain precisely what is explicit or implicit in Gadamer's hermeneutics, a few words 
illuminating inetaphor at this point is the "herineneutical circle": "[a] part can only be understood in the context of the whole, and the whole cannot be understood without analyzing its various parts." 385

Hermeneutics assumes that there is no objectively valid interpretation eubedded in the positive law. Indeed, one cannot even interpret positive law in the abstract; one must have soine concrete context upon which to focus. That context, in turn, sharpens the critical aspects of practical interpretation, enlightening the relevant preunderstandings and horizons and requiring their reconsideration as applied to the facts at hand. Interpretation, then, can becoine a contextually driven transforming event from which behefs in the legal interpretive coininunity evolve.

It follows that judicial interpretation involves creativity and choice ainong competing arguinents and values. Judicial interpretation is driven not by a single, foundational value, but by a complex, interactive assessment and reassessinent of a multitude of factors- $a$ "to and fro moveinent" that continuously tests potential interpretations against the legal interpretive cominunity's web of beliefs. ${ }^{386}$ Because of its antiformakist nature, practical reasoning is better understood by exainining "paradigm cases"-those that serve as worthy examples of the technique-than by more abstract descriptions. Practical reason assumes that we can often learn more froin examining these "paradigm cases," in

of clarification may be in order. Gadamer's hermeneutics can be viewed as a description of the way people inevitably carry out interpretation. At this descriptive level, as I briefly discuss and as Eskridge has more fully explained, hermeneutics is strikingly different from foundationalist and rationalistic methods of interpretation-such as literalism or intentionalism-that judges say they are following. For example, hermeneutics suggests that the fusion of horizons is inevitable; under intentionalism, the current horizon is ordinarily considered inadmissible. This conflict between hermeneutics and foundational interpretive theory as a descriptive matter is an important one for students of statutory interpretation. See generally Eskridge \& Frickey, supra note 22, at 345-84. In my view, hermeneutical insights can also be useful as informing a practical reasoning approach. In Part III, I am using hermeneutics to suggest some qualities that ought to inform the process of interpretation in federal Indian law.

385. Eskridge \& Frickey, supra note 22, at 351.

386. Consider one explanation of the dynamics of legal interpretation from this perspective: Because we always approach texts from the perspective of our own historically situated horizon, we tend to project our "preunderstandings" onto the text, viewed as a whole. That is essential to interpretation, because the preunderstandings are conditioned by tradition and, hence, help us link our horizon with that of the text. But the hermeneutical circle suggests that a true dialogue with the text requires the interpreter to reconsider her preunderstandings as she considers the specific evidence in the case, and then to formulate a new understanding, which in turn is subject to reconsideration. For Gadamer, the essential lesson of the circle metaphor is the hermeneutical attitude: "[A] person trying to understand a text is prepared for it to tell him something." The "to and fro movement" involved in the hermeneutical circle is not just the interpreter's movement from a general view of the statute to the specific evidence and back again; rather, it requires her to test different understandings of the text in an ongoing effort to determine its proper interpretation.

Eskridge \& Frickey, supra note 22, at 352. 
which there is some play between the law, context, and the commumity's web of beliefs, than from foundational theory.

Althougli eclectic, practical reason is not purely ad hoc. Therefore, it is not impossible to aggregate it into generalized theory. Theory, even broad theory, will likely grow over time from paradigmatic cases im a field. It will not be foundationalist, but it might be considered "mid-level theory," providing principles which help reconcile the abstract, sometimes conflicting values in the legal interpretive community's web of beliefs with the concrete settings of the world. In this way, paradigmatic cases help us understand the content of our public law traditions. For exainple, our first amendment tradition may be better illuninated by assessing New York Times v. Sullivan ${ }^{387}$ or Cohen v. California ${ }^{388}$ than by foundational first amendment theory.

Like foundational theory, practical reason requires its users to make a leap of faitl. Practical reason inakes some charitable assumptions about the coinpetency of advocates, who must frame the context and the dialogue. So, too, judges must not only be open-minded, but they must also have the capacity and energy to engage in the complex, hard work of critical interpretation. Unfortunately, tradition and the legal interpretive cominunity's web of beliefs could also produce their share of hidebound or narrow-minded outcoines. ${ }^{389}$ These problems are especially vexing when federal Indian law is viewed froin a practical perspective.

\section{Caring About Context}

American judges-and often the advocates as well-find federal Indian law peculiarly foreign. Few members of the American legal interpretive commumity know anything about federal Indian law, and even fewer know anything about the realities of Indian life and culture. Even "liberal" judges and lawyers might well have only an abstract sympathy for Indian causes that may be trumped by more concrete factors that

387. 376 U.S. 254 (1964), used as a paradigmatic first amendment case in Farber \& Frickey, supra note 353 , at $1631-39$.

388. 403 U.S. 15 (1971), used as a paradigmatic first amendment case in Farber, Civilizing Public Discourse: An Essay on Professor Bickel, Justice Harlan, and the Enduring Significance of Cohen v. California, 1980 DukE L.J. 283.

389. Even if all these problems can be overcome, a behever in practical reason must answer the objections that this method is illegitimate because it involves too much lawmaking by judges and cannot produce objectively valid results. But all interpretation requires judicial creativity, and the counter-majoritarian difficulty should be understood as one of the important preunderstandings shared in the legal interpretive community (and therefore infiuencing judges) rather than some litmus test of methodology. Legislative supremacy is one of our most important values, but we also value the apparent meaning of statutory text (which is all that is formally enacted into law and which provides a source for some certainty in law) and the need to accommodate particular decisions with the broader, evolving public law. One premise of practical reasoning is that it cannot produce objectively valid results, but then agaim neither can intentionalism. For further discussion, see Eskridge, supra note 354; Eskridge \& Frickey, supra note 22. 
conflict with these causes, such as concerns about protecting the civil rights of non-Indians who hive in Indian country. A simple, but potentially devastating question, is whether there is any web of behiefs in the American legal interpretive community concerning federal Indian law. Moreover, even if there is such a web, it may be hopelessly polluted by our history of colonization and our current lack of understanding of Indians. The acontextual nature of foundational theory in federal Indian law exacerbates these problenis. As Vine Deloria, Jr. has put it, "what is missing in federal Indian law are the Indians." 390

A practical approach to federal Indian law would start with a heightened concern for context. In this respect, my thinking about federal Indian law has been heavily influenced by a recent article by Frank Pommersheim. ${ }^{391}$ This article brilliantly translates, into language understandable to the American legal interpretive community, why niembers of that community should care about the tribal context and why we should avoid undermining it when we proinote other values.

Pommersheim is one of the few non-Indian legal scholars-and, unfortunately, there are very few Indian legal scholars-situated to undertake this task. Drawing upon the ten years he lived and worked on the Rosebud Sioux Reservation as an attorney and college professor, Poinmersheim weaves a picture of the reservation not just as a place of poverty and despair, but also as a place of hope and a broadening range of choices. He also eloquently explains that, regardless of historical circumstances, tribal Indians have been committed to remaining "indelibly Indian," "a people apart" resisting "full incorporation into the doninant society around thein." 392 He presents compelling arguinents for these propositions based on his own experiences, not from the abstract perspective of soine anthropologists, historians, or well-ineaning liberals engaged in a little pro bono work. Pomniersheim helps us see beyond the innage of the reservation that one glimpses from the highway and provides a vision of the hunian values at stake in federal Indian law disputes. Poununershein also helps us understand that a sensitivity to the tribal context does not require a coniplete rejection of nodernity or progress. ${ }^{393}$

Pommersheim's approach stands in stark contrast to most attenipts to examme the context of federal Indian law. Conipare the frequently

390. Deloria, supra note 349, at 205.

391. See Pommersheim, The Reservation as Place: $A$ South Dakota Essay, 34 S.D.L. Rev. 246 (1989).

392. Id. at 249.

393. Id. ("Indians and their tribes must encounter and transform modern social, economic, and political conditions in order to achieve a meaningful and flourishing future; an encounter and transformation that must be governed by wise choice and mediated through deeply held cultural values."). 
quoted dictum of Justice Black attempting to justify caring about the reservation context:

It may be hard for us to understand why these Indians cling so tenaciously to their lands and traditional way of life. The record does not leave the impression that the lands of their reservation are the most fertile, the landscape the most beautiful or their homes the most splendid specimens of architecture. But this is their home-their ancestral home. There, they, their children, and their forebears were born. They, too, liave their memories and their loves. Some things are worth more than money and the costs of a new enterprise. ${ }^{394}$

The quotation is eloquent-and hollow. Although an attempt at sensitivity, it can easily be read as saying that these odd people, with their quaint ways, want to reinain in their horrible conditions and continue to he like their primitive ancestors for peculiar reasons, and perliaps courts ouglit to be broad-minded enough not to dismiss their unusual preferences. Frained in such terms, the sympatlyy or guilt regarding tribal Indians that many members of the American legal interpretive community feel is too vague and abstract to withstand any balancing against inore concrete concerns. For example, the seeming unfairness (to any person who cares about equal protection along the lines of Carolene Products theory ${ }^{395}$ ) of subjecting non-Indians to regulation by a tribe in which they have no political riglits inay take precedence over the abstract notion of Indian sovereignty. It should coine as no surprise tliat-as in Oliphant and Brendale, and in Cotton Petroleumwhat is familiar (Carolene equal protection concerns, or the tax treatinent of federal contractors) will trump what is strange and unknown (tribal sovereignty and the reservation context).

The tribal context illuminates wliy tribal Indians wish to remain distinct and self-governing with a geographically defined sovereignty. In teaching federal Indian law, I have found that my students and I approach the cases im a different, inore sophisticated way after reading Pominerslieim's essay at the beginning of the course. For example, issues of reservation diminislinent have a inore meaningful quality when one has read Pommersheim's discussion of the cultural centrality of land to Indian people. ${ }^{396}$ This perspective does not guarantee support for tribal

394. Federal Power Comm'n v. Tuscarora Indian Nation, 362 U.S. 99, 142 (1960) (Black, J., dissenting).

395. The reference is, of course, to United States v. Carolene Products Co., 304 U.S. 144, 152 n.4 (1938), which provides the basis for the elegant theory of representation reinforcement developed in J. Ely, DEMocracy AND Distrust (1980).

396. See Pomniersheim, supra note 391, at 250-62. By focusing on Pommersheim's work, I do not mean to slight the efforts of others, particularly Indian scholars, who have performed important translations of context. See, e.g., V. Deloria, $\mathrm{J}_{\mathrm{R}}$ \& \& C. LYTle, The Nations Within: The Past AND FUTURE OF AMERICAN INDIAN SOVEREIGNTY (1984) (among other things, providing an analytical and historical perspective on the relationship between the Indians and their land). It 
positions in concrete disputes, but it does help enrich and expand the process of practical reasoning.

\section{Traditions, Horizons, and Paradigms}

Standing alone, context is an incomplete coinponent of practical reasoning. Without more, every case would turn on its unique facts, and often there would be no way of resolving conflicts between sincere and thoughtful adversaries. Our legal traditions provide structure and continuity to interpretation and illuminate many of the preunderstandings that inust be incorporated into it. Is there a tradition in the American legal interpretive commumity concerning federal Indian law issues? If so, from a nornative perspective is it worth retrieving?

The federal Indian law tradition defies simple attempts at explanation. For example, im part to justify establishing a clains commission to pay compensation for the historical taking of Indian lands, Felix Cohen wrote:

Every American schoolboy is taught to believe that the lands of the United States were acquired by purchase or treaty from Britain, Spain, France, Mexico, and Russia .... As for the original Indian owners of the contiment, the common impression is that we took the land from them by force and proceeded to lock them up in concentration camps called "reservations."

Notwithstanding this prevailing mythology, the historic fact is that practically all of the real estate acquired by the United States since 1776 was purchased not from Napoleon or any other emperor or czar but from its original Indian owners. ${ }^{397}$

For Cohen, our tradition of buying rather than confiscating Indian lands establishes that compensation should be paid in the (apparently rare) situations when "[w]e have fallen . . from the high national standards we set [for] ourselves." 398

By 1946, Congress liad enbraced soine of this tradition by enacting the Indian Claims Commission Act, ${ }^{399}$ which made compensation available in some circumstances for the taking of Indian lands prior to August $13,1946 .{ }^{400}$ The tradition apparently died on that date, however. In

would be especially harmful and ironic if new attention to the tribal context resulted in giving the writings of non-Indians a privileged status, as I have earlier noted. See Frickey, supra note 30, at 1212. I have focused on the Pommersheim essay because it is recent, short, and seems to resonate with my students.

397. Cohen, Original Indian Title, 32 MINN. L. REv. 28, 34 (1947).

398. Id. at 42.

399. See Indian Claims Commission Act of 1946, ch. 959, § 1, 60 Stat. 1049 (codified at 25 U.S.C. $\$ \$ 70-70 w(1988)$ ) (expired Sept. 30, 1978).

400. See id. ch. 959, $\S 12,60$ Stat. at 1052 (codified at 25 U.S.C. $\S 70 \mathrm{k}$ (1988)); see also Indian Claims Commission Act of 1946, ch. 139, 63 Stat. 102 (codified as amended at 28 U.S.C. $\S 1505$ (1988)) (addressing post-1946 claims). 
Tee-Hit-Ton Indians v. United States, ${ }^{401}$ the Court held that a post-1946 federal taking of Indian aboriginal land interests was not compensable in federal court. The Court concluded that land held in original Indian title-aboriginal title never formally ratified by Congress as an AngloAmerican title through treaty, agreement, or statute-was not "property" for purposes of the fifth amendment's taking clause. In a none too subtle slap at Cohen, Justice Reed's majority opinion stated:

Every American schoolboy knows that the savage tribes of this continent were deprived of their ancestral ranges by force and that, even when the Indians ceded millions of acres by treaty in return for blankets, food and trinkets, it was not a sale but the conquerors' will that deprived them of their land. ${ }^{402}$

On its facts and reasoning, Tee-Hit-Ton was outrageous. ${ }^{403}$ More important for our purposes, however, is the essential hollowness of both the Cohen and the Reed formulations of the federal Indian law tradition. Both grossly oversimplify the history and read like advocacy. Moreover, both approaches assume that the return of lands to the Indians is unthinkable (Cohen's, in saying we should pay the Indians for uncompensated takings of land; Reed's, in denying any need to do so). A contextual approach, on the other hand, would suggest that the land has far more significance to Indians than money does. ${ }^{404}$

If we are ever to iniprove upon the Cohen-Reed debacle, we must take more coinplete account of both tradition and context. Because John Marshall is the creator of much of whatever constitutes our federal Indian law tradition, examining his opinions might reveal many aspects of that tradition-indeed, might illuminate what it means to function as an Anglo-American judge in this area.

On one reading, Chief Justice Marshall avoided the critical interpretation of practical reason, relying instead upon Anglo-American preunderstandings. In his first important federal Indian law opinion,

401. 348 U.S. 272 (1955).

402. Id. at $289-90$.

403. Even if Justicc Reed's theory of conquest had made sense of much of what occurred in the continental United States, the case before him dealt with aboriginal title in Alaska, where no Seventh Cavalry had ever fought it out with natives. As Nell Jessup Newton has wryly put it, "[t]he only sovereign act that can be said to have conquered the Alaska native was the Tee-Hit-Ton opinion itself." Newton, supra note 23, at 1244.

404. The experience with the Black Hills claim makes this clear. After recovering a substantial judgment in the proceedings that culminated in United States v. Sioux Nation of Indians, 448 U.S. 371 (1980), the tribes involved have refused to take the money, insisting instead on the return of land. As the money accrues interest in the federal treasury, these natives continue to press their claim for land in Congress. Senator Bradley has introduced legislation that would return sotne public lands in the Black Hills to thetn. See Sioux Nation Black Hills Act: Hearing on S. 1453 Before the Select Comm. on Indian Affairs, 99th Cong., 2d Sess. (1986). 
Johnson v. McIntosh, ${ }^{405}$ Chief Justice Marshall seemingly held ${ }^{406}$ that European nations obtained legal title to North America simply by virtue of their explorers' discovery of the contiment. Tribes possessed only a right of occupancy that was subject to defeasance by the European sovereign holding legal title either through purchase or conquest. In his second major opinion, Cherokee Nation v. Georgia, ${ }^{407}$ Chief Justice Marshall demied that a tribe was a foreign sovereign under international law, relegating its status to a "doinestic dependent nation" confined to a paternalistic wardship under the federal government. In the third important case, Worcester v. Georgia, ${ }^{408}$ he held that states had no sovereignty over Indian country, a conclusion beneficial to tribes but perhaps compelled mostly by the Chief Justice's federalist perspective. As a collection, these cases may well suggest that Chief Justice Marshall was more concerned with centralizing in the federal government all important powers over Indians and their lands than with the normative consequences of colonization.

There is some truth in this conclusion, which may help explain much of the hollowness of the tradition of preserving Indian sovereignty. Nonetheless, Chief Justice Marshall's opmions reveal more hermeneutical spirit and help establish a more normatively attractive vision of our federal Indian law tradition than this conclusion suggests.

John Marshall could not ignore his role as Chief Justice of the highest court of a colonizing government. Unlike Justice Reed in Tee-HitTon, ${ }^{409}$ however, he at the very least acknowledged the normative contingency of colonial preunderstandings. The doctrines of discovery, conquest, and original Indian title, though justified because they were "indispensable to that system under which the country has been settled, and ... adapted to the actual condition of the two people," were perhaps "extravagant ... pretension[s] ... opposed to natural right, and to the usages of civilized nations." 410 In Cherokee Nation, Chief Justice Marshall deplored Georgia's attempt to destroy the Cherokee's sovereignty, ${ }^{411}$ and by Worcester he seemed to express serious qualms about

405. 21 U.S. (8 Wheat.) 543 (1823).

406. For revisionist readings of this case that are more respectful of tribal sovereignty, see Ball, supra note 341, at 23-29; Henderson, Unraveling the Riddle of Aboriginal Title, 5 AM. INDIAN L. REV. 75, 87-96 (1977).

407. 30 U.S. (5 Pet.) 1 (1830); see supra text accompanying notes 209-14.

408. 31 U.S. (6. Pet.) 515 (1832); see supra text accompanying notes $215-17$.

409. See supra text accompanying notes 401-04.

410. McIntosh, 21 U.S. (8 Wheat.) at 591-92.

411. Chief Justice Marshall began his opinion in Cherokee Nation as follows:

This bill is brought by the Cherokee nation, praying an injunction to restrain the state of Georgia from the execution of certain laws of that state, which, as is alleged, go directly to annihilate the Cherokees as a political society, and to seize, for the use of Georgia, the 
the normative basis for the colonization of North America. ${ }^{412}$

Ultimately, Chief Justice Marshall tried to do the best he could to approach colonial preunderstandings critically, to reinain true to his position in the colonizing government while accommodating a different perspective. In Worcester he stated:

[P]ower, war, conquest, give rights, which, after possession, are conceded by the world; and which can never be controverted by those on whom they descend. We proceed, then, to the actual state of things, having glanced at their origin; because holding it in our recollection might shed soine light on existing pretensions. ${ }^{413}$

As described in Cherokee Nation and Worcester, where Chief Justice Marshall's vision seems to have matured while considering Georgia's attempt to incorporate the Cherokee, the "actual state of things" was a blend of history and normative nuance that would surprise someone like Justice Reed.

First, Chief Justice Marshall wrote that the notion that the discovery of North America and settlement of its sea coast alone gave Europeans authority over Indians and the right to occupy their lands was an "extravagant and absurd idea," that "did not enter the mind of any inan."414 Instead, under international law concepts used by European

lands of the nation which have been assured to them by the United States in solemn treaties repeatedly made and still in force.

If courts were permitted to indulge their sympathies, a case better calculated to excite them can scarcely be imagined. A people once numerous, powerful, and truly independent, found by our ancestors in the quiet and uncontrolled possession of an ample domain, gradually sinking beneath our superior policy, our arts and our arms, have yielded their lands by successive treaties, each of which contains a solemn guarantee of the residue, until they retain no more of their formerly exclusive territory than is deemed necessary to their comfortable subsistence. To preserve this remnant, the present application is made.

30 U.S. (5 Pet.) at 15.

412. Chief Justice Marshall wrote:

America, separated from Europe by a wide ocean, was inhabited by a distinct people, divided into separate nations, independent of eacl otler and of the rest of the world, having institutions of their own, and governing themselves by their own laws. It is difficult to compreliend the proposition, that the inhabitants of either quarter of the globe could have rightful original claims of dominion over the inhabitants of the otlier, or over the lands they occupied; or that the discovery of either by the other slould give the discoverer rights in the country discovered, which annulled the pre-existing right of its ancient possessors.

After lying concealed for a series of ages, the enterprise of Europe, guided by nautical science, conducted some of her adventurous sons into this western world. They found it in possession of a people who had made small progress in agriculture or manufactures, and whose general employment was war, liunting, and fisling.

Did these adventurers, by sailing along the coast, and occasionally landing on it, acquire for the several governments to whom they belonged, or by whom they were commissioned, a rightful property in the soil, from the Atlantic to the Pacific; or rightful dominion over the numerous people who occupied it? Or has nature, or the great Creator of all things, conferred these rights over hunters and fishermen, on agriculturalists and manufacturers?

Worcester, 31 U.S. (6 Pet.) at 542-43.

413. Id. at 543 .

414. Id. at $544-45$. 
nations to sort out their respective rights to colonize new worlds, the European colonizers simply had "the exclusive right of purchasing such lands as the natives were willing to sell." ${ }^{\prime 15}$ Note that conquest, mentioned in Chief Justice Marshall's first opinion as a legitimate means of obtaining Indian land, was conspicuously absent in the reformulation of law found in the third opirion.

Second, he noted that the early colonial charters revealed that the colonizers were notivated in part by the object of converting the Indians to Christianity. Chief Justice Marshall stressed that conversion would be better acconiphished "by conciliatory conduct and good example; not by extermination." ${ }^{\prime 16}$

Third, Great Britain, fron which the United States inherited its tradition, considered the tribes to be "nations capable of nuaintaining the relations of peace and war; of governing themselves, under her protection; and she nrade treaties with then, the obligation of which she acknowledged."417 Thus, "our history furnishes no exaniple . . . of any attempt on the part of the crown to interfere with the internal affairs of the Indians, farther than to keep out the agents of foreign powers, who, as traders or otherwise, might seduce them into foreign alliances."418 Accordinig to the Chief Justice, the United States had continued to carry on this tradition of respecting tribal sovereignty. ${ }^{419}$

Chief Justice Marshall's reconstruction of Anglo-American preunderstandings $\dot{n} 1$ hight of the Cherokee Nation's plight cannot be fully satisfactory from the tribal perspective. Note, however, how equally unpalatable it is fron the perspective of the unilateral colonizer, like Justice Reed in Tee-Hit-Ton. Practical interpretation nust be critical rather than inechamical im identifying and evaluating preunderstandings and in fusing horizons, but it cannot escape the boundaries imposed by operating within a legal interpretive conımunity in the AngloAmerican legal tradition; indeed, in this case, it operated within the federal governinent itself. This situatedness can have profoundly conservative influences, but that seems inevitable. ${ }^{420}$ Every year in my class, I ask the students to put themselves in Chief Justice Marshall's shoes. Was he a racist? Could you have done better in the circumstances? I have yet to get a response that struck nie as both niore normatively attractive than Chief Justice Marshall's work and capable of surviving in his interpretive coinununity.

415. Id. at 545 .

416. Id. at 546.

417. Id. at 548-49.

418. Id. at 547.

419. Id. at 549-50 (stating that Congress followed this tradition to keep peace with the Indians and to prevent their siding with Great Britain during the colonies' struggle for independence).

420. For a thoughtful discussion, see Eskridge, supra note 354. 
Chief Justice Marshall again used his contextual sensitivity when he turned more squarely to the dispute involving the Cherokee. The tribe's treaties with the Umited States did not expressly reserve sovereignty for the tribe. As discussed earlier, the Chief Justice examined the circumstances under which the earliest treaties had been negotiated, found their spirit to be consistent with tribal sovereignty, and created a canon to interpret them so they did not covertly destroy tribal self-government. ${ }^{421}$

This did not end the matter, however, because Chief Justice Marshall was writing in 1832, and the treaties he focused on had been entered into in 1785 and 1791. In the intervening years, eastern tribes like the Clierokee had lost much of their military strength, the federal government was operating on the assumption that it had plenary power over tribes, and Andrew Jackson, a noted non-behever in tribal sovereignty, was elected President. In a series of treaties with the United States after 1791, the Cherokee lost an increasingly larger proportion of their original land base. ${ }^{422}$

Chief Justice Marshall could have concluded that, regardless of what the first treaties suggested, the circumstances surrounding the negotiations of the later treaties implicitly diminished or destroyed tribal sovereignty. Instead, he treated the first treaties (read against the canon of clear statement about invasions of tribal sovereignty) as controlling the case, in effect establishing a sovereign-to-sovereign relationship that could be destroyed only by a clear statement in a later treaty. ${ }^{423}$ Again, Chief Justice Marshall's opinion in Worcester exemplifies an important liermeneutical insight: imterpretation requires an encounter with a specific context, which can have a transforming effect. ${ }^{424}$ His encounter with the Cherokee context in his second and third opinions seemingly transformed federal Indian law from the largely unilateral colomialism of his first opinion.

Chief Justice Marshall's contextual inquiry demonstrates two important aspects in which the federal Indian law tradition contains respect for tribal sovereignty. First, it shows that the canons of interpretation, which Marshall established, are not necessarily lollow or resultoriented conceptualisms. In many modern cases, the canons are nientioned in form but ignored in substance, probably because they have no contextual linkage and therefore appear rather quaint and silly, like old maxims in equity. For mstance, im Cotton Petroleum the Court mouthed

421. See supra text accompanying notes 215-17.

422. For an overview of the several treaties involving the Cherokee, see C. ROYCE, THE CherokeE Nation of INDIANS (1975).

423. See Collins, supra note 345 , at 375-76.

424. See generally Eskridge, supra note 354 (evaluating Gadamer's theory of hermeneutical interpretation). 
the canons, but did not engage in interpretation consistent with them, apparently because the majority saw no relevant difference between a non-Indian coinpany contracting with a tribe and one employed by the federal government. ${ }^{425}$ Chief Justice Marshall's work stands in stark contrast.

In practical reasoning, canons can serve a critical interpretive role. They constitute a shorthand method of identifying the relevant public law tradition-indeed, of promoting a critical evaluation of the judge's own preunderstandings. ${ }^{426}$ For example, rather than simply assuming that tribal and federal contractors should be on the saine footing, the canons suggest that doubts should be resolved in favor of tribal independence. The Court in Cotton Petroleum should have worked lard to identify reasons why our tradition may suggest a contrary result and then honestly assessed thein. The canons are part of a tradition to be incorporated-indeed, they should tip us off that the rest of that tradition reinains to be identified and evaluated-and not simply treated as maxims to be quoted as a matter of opmion drafting.

Second, Chief Justice Marshall's approach encourages critical assessinent of colomial preunderstandings by ineasuring Indian interests from their strongest historical perspective, even if (as was the case in the Cherokee dispute) in the contemporary circumstances they seem weaker. Essentially, in critically balancing the interests of the colonizing governinent and the victions of colonization, Chief Justice Marshall decided that it should not count against Indian interests that colonization was taking a toll. ${ }^{427}$

In effect, the Chief Justice undertook indirectly what he eschewed directly. As a formal inatter, he continued to assume that he could not entertain fundamental challenges to colonization. As a functional matter, he apparently allowed his normative qualms about colonization to lead him to create a method of interpretation that presuined tribal sovereignty to be substantial as a inatter of law even if weak as a matter of fact. This approach has the practical effect of avoiding judicial decisions that find inplicit diminishinent of tribal sovereignty. Chief Justice Marshall forced the Congress, as the governmental branch politically accountable for the implementation and consequences of colonization, to destroy the sovereignty of tribes overtly if sovereignty was to be lost at all. He atteinpted to keep the states-where local pressures are likely to be extraordinarily hostile to tribal independence-out of the business of

425. See supra text accompanying notes 259-64.

426. See Eskridge, supra note 354, at 620-24; Eskridge, supra note 221; Sunstein, supra note 221.

427. For an interesting discussion of the Court's sometime protection of Indian interests against the ravages of time, see C. WILKINSON, supra note 6 , at 32-52. 
colonization altogether. ${ }^{428}$

Chief Justice Marshall thus mediated a fascinatimg tension among positivisn1, situatedness, and norms. From the positivist perspective, he was operating under a Constitution that lacks language attenıting either to deprive tribes of sovereignty or to incorporate them into the United States unilaterally. Its only express grant of congressional power involves the regulation of commerce with tribes. Yet by the $1820 \mathrm{~s}$ and 1830s, colonization was well-rooted entpirically and, in Anglo-American society, normatively as well. Situatedness, not positivisn, was thus the primary barrier to Chief Justice Marshall's use of norms gleaned fronı the higher, natural law. ${ }^{429}$ By a critical evaluation of the preunderstandings of colonization and a clever assessnent of conparative institutional coinpetence, he inelded higher-law norms with the situatedness surrounding him.

Chief Justice Marshall's opinion in Worcester provides a useful paradigm for considering what it means to "do federal Indian law." By this I do not nrean that it conld not have been improved, or that I am attracted to all the consequences that follow froin it, or that Chief Justice Marshall was soniehow free of Anglo-American ethnocentrisin. What I do nean is that it illuminates the core issues in federal Indian law and how one of our greatest jurists attenipted to cope with thein. It reveals a judge whose hands were on the wheel, atteinpting to nediate clashes of values and perspectives, to evaluate critically preunderstandings as best he could from his own situation, rather than siniply drifting along with dominant sentinients or taking general legal concepts from other areas and forcing then into the corpus of federal Indian law. It shows a judge who could modify his views over time, for exainple, about conquest as a valid inethod of defeasing original Indian title. Moreover, it reveals a jurist who courageously challenged the politically accountable branches to promote a result that critically undercut the preunderstandings of those branches. Because of the strident states' rights and anti-Indian views of the southern states and President Jackson, the decision in Worcester iniperiled our very constitutional structure, to say nothing of the Court as an institution. ${ }^{430}$

428. Chief Justice Marshall's sensitivity to institutional nuance suggests that modern scholars interested in comparative institutional competence and public choice might find fertile ground in federal Indian law.

429. This contrasts with Chief Justice Marshall's approach to the slave trade, which he thought obviously violated "the law of nature," see The Antelope, 23 U.S. (10 Wheat.) 66, 120 (1825), but which in his day had been protected by positive constitutional provision, U.S. CoNST. art. I, $\S 9$, and was rooted in American practice. Protecting tribal sovereignty may be "extra-constitutional," see supra note 381, but invalidating slavery would have been "contra-constitutional."

430. See, e.g., Burke, The Cherokee Cases: A Study in Law, Politics, and Morality, 21 STAN. L. REV. 500, 500, 509 (1969). 
To be sure, in legitimating federal control over tribes and providing for the orderly acquisition of Indian lands, the work of Chief Justice Marshall is not pristine enough normatively for the international human rights theorist. From a practical perspective, however, it inay well reflect the inost that can be expected. Indeed, as Tee-Hit-Ton and other cases indicate, later generations of jurists have frequently lost touch with this tradition. Froin the perspective of practical reason, retrieving Chief Justice Marshall's inethodology might protect tribal self-determination more than any formal, conceptual theory could.

Chief Justice Marshall's tradition is, of course, not the only one in our history. Robert A. Williams, Jr., has eloquently detailed the discourse of domination that took root in many non-Indians durimg the colomial period and thereafter, ${ }^{431}$ and that seemed to have descended undiluted upon Justice Reed in Tee-Hit-Ton. ${ }^{432}$ Milner Ball has explaimed how contemporary American visions of equality-the value of umformity over umqueness ${ }^{433}$-intrude upon any critical dialogue about Indian self-determination in the late twentieth century. ${ }^{434}$ It is pointless to ignore these realities by calling them irrelevant, as some foundationalist theories do. But practical reason requires critical analysis of preunderstandings and tradition and a fusion of horizons, not blind incorporation of our past. A retrieval of Chief Justice Marshall's inethod, an appreciation of the normative unattractiveness of the coinpetimg tradition of colomization, and a nuanced assessinent of the values of uniformity and uniqueness are goals with the virtue of confronting what ails us, rather than obviating the obvious. ${ }^{435}$

431. See Williams, Documents of Barbarism: The Contemporary Legacy of European Racism and Colonialism in the Narrative Traditions of Federal Indian Law, 31 ARIz. L. REV. 237 (1989); Williams, Jefferson, the Norman Yoke, and American Indian Lands, 29 ARIz. L. REV. 165 (1987). Professor Williams has now collected and expanded his work in R. WILLIAMs, THE AMERICAN INDIAN IN Western Legal Thought: The Discourses of CoNQuest (1990).

432. See supra text accoinpanying notes 401-04.

433. See supra text accompanying notes 322-28.

434. See Ball, Stories of Origin and Constitutional Possibilities, 87 MiCH. L. REV. 2280, 2306-19 (1989).

435. Context and tradition will only lead to practical reasoning if they are components in a true dialogue. There are siguificant factors inhibiting such a dialogue in federal Indian law today, affecting both the Indians' ability to communicate their perspective and the non-Indians' presumptions about what Indians are likely to say. Although tribes are often effectively represented in federal litigation, their advocates must often make concessions based on the current state of the law, concessions that can too easily be confused with the true Indian feelings on an issue.

When attorneys representing the Sioux Nation in United States v. Sioux Nation of Indians, 448 U.S. 371 (1980), conceded that no legal theory existed under which the courts could order the federal government to return the Black Hills, the lawyers were accurately acknowledging the state of federal law. When the attorneys obtained a substantial judgment for the taking of the Black Hills, their chents refused to take the money, instead asserting a right to a return of the land. Less vivid barriers to judicial understanding of the Indian perspective arise every day, for example, when an advocate for a tribe bases a claim on the federal-tribal trust relationship, as in the Mitchell cases. It ought to go without saying that litigation of that sort does not necessarily mean that Indians approve 


\section{The Court, the Congress, and Contemporary Federal Indian Law}

To a great extent, Parts I and II suggest that the Court has often engaged in soine degree of practical reasoning in federal Indian law disputes. Part I deinonstrates that foundational theory has not controlled many important cases, and Part II indicates that a variety of practical considerations probably influenced these decisions. Yet inuch can be said in criticism of the Court's performance.

At a minimum, these opinions routinely lack candor about the consideration of practical factors. Of all the cases discussed, Bryan, the state tax case under Public Law 280, came closest to acknowledging that evolutive factors were controlling, yet that discussion was buried in a footnote. ${ }^{436}$ Often, as in Menominee Tribe, the termination case, the Court failed to admit that any fusion of horizons was occurring. ${ }^{437}$ Solem, the reservation diminishment case, is perhaps the most curious of all, with the Court cycling back and forth between obfuscation (pretending that congressional intent was the governing factor) and candor (admitting that in context no such intent could be discerned and that evolutive considerations were controlling). ${ }^{438}$

These opinions as a whole create httle confidence that the Court even recoginzes the extent to which practical reasoning is influencing its decisions. Still less do the opinions provide hope that the Court's methodology contains the best elements of practical reasoning: open-inindedness, critical assessinent of traditions and preunderstandings, and fusion of horizons. These problems are not unique to federal Indian law, ${ }^{439}$ but they are of greater impact here, where the context, tradition, and preunderstandings are often more opaque than in areas less foreign to the Justices. These difficulties suggest an even more fundainental problem with practical reasoning in federal Indian law than the substantial impedinents already identified. The methodology might sinuply be beyond the capacities of American judges. ${ }^{440}$

Practical reasoning can look inipressive indeed when a scholar

of domestic dependent nationhood status and plenary congressional power. Moreover, there is incredible diversity within and across tribes about all manner of issues, and tribes exist in quite diverse situations. Thus, it is a mistake to assume that there is one Indian perspective on a problem. Finally, as my colleague Gerald Torres has eloquently explained, fitting the actual condition of Indian groups into Anglo-American legal constructs may often produce a distorted dialogue. See Torres \& Milun, Translating Yonnondio by Precedent and Evidence: The Mashpee Indian Case, 1990 DUKE L.J. 625 (forthcoming 1990).

436. See supra text accompanying note 231 .

437. See supra text accompanying notes 223-31.

438. See supra text accompanying notes 66-77.

439. See Eskridge \& Frickey, supra note 22, at 364-71.

440. See generally Weisberg, The Calabresian Judicial Artist: Statutes and the New Legal Process, 35 StAN. L. Rev. 213, 253 (1983) (suggesting that judicial capacity is too limited to implement antiformahism in any thoughtful manner). 
spends months carefully evaluating one interpretive issue. ${ }^{441}$ In dozens of pages, such scholarship can meticulously discuss preunderstandings and traditions, contexts and horizons, engaging $i m$ the to and fro movement of construction of meaning. It is quite another thing to expect the same from overworked American judges. All these judges lack the time, some may lack the ability, and all may end up depending too much on counsel, who may construct the case madequately. The Supreme Court-which controls its agenda and has the help of a swarm of law clerks and, sometimes, good counsel-might be able to exercise practical reason in fields of law that are most familiar, where traditions, preunderstandings, and context may be most apparent and understandable to members of the legal interpretive community. But in federal Indian law, doubts about judicial capacity suggest that everyone might be better off with some ineasure of formalism, even if it masks practical reasoning to some extent.

The Court's modern decisions that we have examined provide no paradigms for rebutting this challenge. Although the reader who lacks independent knowledge of federal Indian law may feel overwhelmed by the sheer number of cases we have seen, one last retreat to the Court's corpus of opinions will produce useful examples of practical reasoning. In two contemporary areas of controversy, the Court reached decisions that are paradigms of practical reasoning and that may provide substantial methodological guidance.

In Williams v. Lee, ${ }^{442}$ the Court held that a tribal court has exclusive jurisdiction over a suit brought by a non-Indian business operating in Indian country agamst a reservation Indian for alleged failure to pay for goods sold on credit. What about the flip side of the problein, where an Indian plaintiff brings suit against a non-Indian defendant in tribal court for a cause of action that arose in Indian country? Oliphant, which held that tribal courts lack criminal jurisdiction over non-Indians, ${ }^{443}$ suggests that subjecting the non-Indian civil defendant to the tribal court raises such serious civil rights questions that perhaps jurisdiction is inconsistent with the tribe's domestic dependent nation status. Since Williams v. Lee seetningly prohibits the non-Indian from seeking state judicial relief against the tribal court action, she will naturally look to the federal courts.

In two cases that are good examples of practical reasoning, the Supreme Court has addressed federal jurisdiction and adjudication of such controversies. In National Farmers Union Insurance Co. v. Crow

441. See, e.g., Eskridge, supra note 354.

442. 358 U.S. 217 (1959), discussed at supra notes 181-83 and accompanying text.

443. See supra note 143 and accompanying text. 
Tribe of Indians, ${ }^{444}$ a non-Indian defendant school district and its insurance company attempted to avoid a tribal court default judgment by obtaining federal injunctive rehef. They asserted federal question jurisdiction, contending that the issue of tribal court civil jurisdiction over non-Indian defendants was a question of federal common law. ${ }^{445}$ The Court unanimously agreed, but nonetheless held that the federal district court inust require the exhaustion of tribal judicial remedies on the jurisdictional issue before considering any relief. ${ }^{446}$

The Court found some formal reasons to distimguish Oliphant. ${ }^{447}$ More important for our purposes, the Court sensibly concluded that, consistent with federal policy encouraging tribal self-government, the tribal court should be the institution that, $\dot{m}$ the first instance, considered whether it may appropriately exercise jurisdiction in the circumstances. The Court acknowledged that the tribal court was the more competent institution to consider the traditional and contextual factors bearing on any such jurisdiction, and that the exhaustion requirement also promoted the efficient administration of justice. ${ }^{448}$

Two years later, in Iowa Mutual Insurance Co. v. LaPlante, ${ }^{449}$ the Court used similar reasoning when a non-Indian company, upon losing its motion to dismiss a suit against it in tribal court, brought a federal declaratory judgment action based on diversity of citizenship. The Court

444. 471 U.S. 845 (1985).

445. Id. at $850-53$.

446. Id. at 853-57.

447. First, in civil cases there are no federal statutes expressly providing federal jurisdiction, as is true for many crines committed by non-Indians in Indian country. Second, it was not clear that the branches of the federal government had long shared the assumption that tribal court civil jurisdiction over non-Indians was unavailable, as the Court had assumed about crininal jurisdiction in Oliphant. Id. at 854-55.

448. The Court stated:

[T]he existence and extent of a tribal court's jurisdiction will require a careful exannination of tribal sovereignty, the extent to which that sovereignty has been altered, divested, of diminished, as well as a detailed study of relevant statutes, Executive Branch policy as embodied in treaties and elsewhere, and administrative or judicial decisions.

We believe that examination should be conducted in the first instance by the Tribal Court itself. Our cases have often recognized that Congress is committed to a policy of supporting tribal self-government and self-determination. That policy favors a rule that will provide the forum whose jurisdiction is being challenged the first opportunity to evaluate the factual and legal bases for the challenge. Moreover the orderly administration of justice in the federal court will be served by allowing a full record to be developed in the Tribal Court before either the inerits or any question concerning appropriate relief is addressed. The risks of the kind of "procedural nightmare" that has allegedly developed in this case will be minimized if the federal court stays its hand until after the Tribal Court has had a full opportunity to determine its own jurisdiction and to rectify any errors it may have made. Exhaustion of tribal court renedies, noreover, will encourage tribal courts to explain to the parties the precise basis for accepting jurisdiction, and will also provide other courts with the benefit of their expertise in such matters in the event of further judicial review.

Crow Tribe, 471 U.S. at 855-57 (footnotes omitted).

449. 480 U.S. 9 (1987). 
held that the federal district court could not exercise jurisdiction until the tribal court had the opportunity to determine its own jurisdiction. Regardless of the basis for federal jurisdiction, the Court held that "unconditional access to the federal forum would place it in direct competition with the tribal courts, thereby impairing the latter's authority over reservation affairs," and would infringe "upon tribal lawmaking authority, because tribal courts are best qualified to interpret and apply tribal law."450 LaPlante is particularly supportive of tribal courts, concluding that the federal district court must stay its hand until tribal appellate review is complete. ${ }^{451}$

Taken together, Crow Tribe and LaPlante represent an effective exercise of practical reason. Neither of the alternative fornal concepts that could have resolved the dispute-that tribal courts have the sovereignty to hear these cases, or that authority is precluded under Oliphant-appears practical at present. The federal courts, including the Supreme Court, have very hittle experience with the structure, operation, and outcomes of tribal court systems. Generalizing a formal theory of tribal court jurisdiction might ignore important contextual differences. Essentially, the Supreme Court has given tribal courts the chance to show that they can fairly and effectively hitigate civil disputes involving non-Indian defendants. The task of accommodating Anglo-American procedural and substantive values while preserving Indian traditions of dispute resolution is a daunting one, ${ }^{452}$ but the Court has given tribal courts the breathing room to undertake the effort. In this context, at least, at some point forinalism may follow function. Moreover, as LaPlante noted, ${ }^{453}$ if the Supreme Court gets it wrong (or even if the Court gets it right), Congress can change the result.

Crow Tribe and LaPlante seein to be effective paradigms of what "doing federal Indian law" in the modern context is all about. ${ }^{454}$ The cases approach the probleins with respect for the tradition of Indian sovereignty, avoid adopting formal concepts that sweep away potential contextual concerns, and ultimately place the dispute where the best case for tribal sovereignty can develop, in a case-by-case, contextual inanner consistent with Indian tradition and contemporary circumstances. These

450. Id. at 16.

451. The Court stated that "[t]he federal policy of promoting tribal self-government encompasses the development of the entire tribal court system, including appellate courts." Id. at 16-17.

452. For enhightening guidance on how tribal courts might attempt to construct a contcxtual legitimacy for adjudicating such cases, see Pommersheim, The Contextual Legitimacy of Adjudication in Tribal Courts and the Role of the Tribal Bar as an Interpretive Community: An Essay, 18 N.M.L. REV. 49, 59-71 (1988).

453. 480 U.S. at 17 n.9.

454. For a good contextual analysis of the implications of these decisions, see Pommersheim, The Crucible of Sovereignty: Analyzing Issues of Tribal Jurisdiction, 31 ARIz. L. REV. 329 (1989). 
cases also suggest that important federal Indian law issues need not be judicially divisive: Crow Tribe was a unanimous decision, and LaPlante involved only one partially dissenting Justice. The votes of that Justice, however, illustrate the contemporary Court's fundamental problems with federal Indian law cases.

Justice Stevens, who wrote Crow Tribe, partially dissented in LaPlante. He agreed that the federal district court in LaPlante should not interfere with tribal court proceedings. Since both the federal court and the tribal court had jurisdiction, however, he behieved that the federal court should proceed to the merits of the dispute regardless of what the tribal court did. ${ }^{455}$ As in Cotton Petroleum, where Justice Stevens saw no reason to treat contractors with tribes differently from federal contractors, in LaPlante he saw no reason to treat parallel hitigation in federal and tribal courts any differently from parallel hitigation im federal and state courts, where the federal courts need not wait for state proceedings to be exhausted. Federal proceedings "would imply no disrespect for the Blackfeet Tribe or for its judiciary. It would merely avoid what I regard as the anounalous suggestion that the sovereignty of an Indian tribe is in some respects greater than that of the State of Montana, for example." 456

Once again, we are back to the conflict between uniqueness and uniformity which plagues federal Indian law issues. ${ }^{457}$ For Justice Stevens, the thought that a contractor with a tribe has greater state tax imnunity than one who contracts with the federal government, or that tribal courts deserve more deference than state courts, is simply ridiculous: tribal governments stand below the federal and state governments. With all due respect, this instinct cannot make up by virtue of symmetry what it lacks in practical reasoning. Justice Stevens' approach contains little of the critical perspective, tradition, and contextual and institutional sensitivity that one finds in Chief Justice Marshall's important cases. These factors require that we, like Marshall, seriously investigate the Indian claim to uniqueness and critically assess the utility of legal uniformity.

County of Oneida v. Oneida Indian Nation ${ }^{458}$ serves as the final recent paradigmatic decision. The Oneida claimed that in 1795 their ancestors had transferred land to the State of New York in violation of federal common law and the federal Trade and Intercourse Act of

455. LaPlante, 480 U.S. at 20-22 (Stevens, J., concurring in part and dissenting in part).

456. Id. at 22.

457. See supra text accompanying notes $322-30$.

458. 470 U.S. 226 (1985). 
$1793,{ }^{459}$ which outlawed any land transaction with a tribe without federal approval. Justice Powell, for a bare majority of five Justices, con. cluded that the tribe had a federal common law cause of action to enforce its aboriginal title to these lands; that no federal statute of limitations apphed; that it would be inconsistent with federal policy to borrow a state statute of limitations; and that the defense of laches was unavaila. ble, in large part because the defendants had not asserted it in the court of appeals. ${ }^{460}$ Accordingly, as the inajority held, the Oneida inay pursue their nearly 200 -year-old claim!

Not surprisingly, four Justices disputed this remarkable holding, and, also not surprisingly, Justice Stevens wrote the dissent. Again, Justice Stevens complained that the Court was deviating from uniform Anglo-American legal principles. For him, the decision was "an unprecedented departure from the wisdom of the coininon law," which required the adjudication of causes of action within a reasonable tine, especially for causes of action concerning land titles. ${ }^{461} \mathrm{He}$ would have applied laches and barred the claim. ${ }^{462}$

Whether the Oneida should have been time-barred is, in fact, a surprisingly complex factual inatter ${ }^{463}$ which the inajority elided. Much of Justice Powell's opinion is written in conventional, formal style that may detract from the essential contextual components of the controversy. An untraditional penultimate paragraph in Oneida, however, provides the most solid foundation for the decision.

Justice Powell began by noting the tradition of preserving tribal rights, and then observed that the Solicitor General had urged affirmance of the judgment the Oneida had won below. Justice Powell continued: "[The Solicitor General] recognized, as we do, the potential consequences of affirnance. [He] observed, however, that 'Congress has enacted legislation to extinguish Indian title and claims related thereto in other eastern States, ... and it could be expected to do the same in New York should the occasion arise.'. . . We agree that this litigation inakes abundantly clear the necessity for congressional action." 464

When fully considered, Oneida seems true to the tradition of John Marshall. Rather than applying generally applicable legal doctrine developed to fit Anglo-American problems, the Court critically assessed

459. 1 Stat. 329 (1793).

460. Oneida, 470 U.S. at $233-45$.

461. Id. at 256 (Stevens, J., dissenting).

462. Id. at 262 .

463. See Clinton \& Hotopp, Judicial Enforcement of the Federal Restraints on Alienation of Indian Land: The Origins of the Eastern Land Claims, 31 ME. L. REv. 17, $42-49$ (1979) (providing a variety of reasons why tribes were effectively unable to assert aboriginal title claims until recently).

464. Oneida, 470 U.S. at 253 (quoting Brief of the United States as Amicus Curiae at 20) (citations omitted). 
the legal preunderstandings in this context. Ultimately, it decided to approach the issue of precluding the Oneida's cause of action grudgingly, and it refused to go further than a technical reading of formal law required. As Chief Justice Marshall did, the Court expected Congress to carry the burden of resolving the consequences of colonization, even in the contemporary context-indeed, one might say, especially in the contemporary context. John Marshall faced situations in which the Court accoinmodated colonization by necessity; no other entity was as well situated to rationalize the underlying premises of colonization, such as original Indian title, the exclusive tribal-federal relationship, and the sovereignty of tribes. Chief Justice Marshall's own situatedness essentially required him to incorporate some aspects of colonization into American public law. Today, however, it is difficult to see why the Court should give any special solicitude to argnments for expanding the influence of colonization, especially when Congress has authority to take that perspective into account.

Cases like Crow Tribe, LaPlante, and Oneida suggest that the present Court can sonetimes perform practical reasoning in federal Indian law. Justice Stevens' dissents in LaPlante and Oneida, as well as his majority opinion in Cotton Petroleum, also denionstrate that the hold of practical reasoning is fragile at best. That Justice Stevens-who often epitomizes the practical reasoner in other cases ${ }^{465}$ - has uncritically adopted the Anglo-American preunderstanding of legal uniformity im these disputes is especially troubling. It seens safe to say that foundationalist arguments of the Indian law faith have had no sway with him. Sonie retrieval of the tradition of John Marshall, and some greater respect for the multiple factors in these cases, may hold more promise.

Finally, it is essential to note what practical reasoning in federal Indian law is not. It is not blind acceptance of the Indian position in a case. Indeed, an appreciation for context, a critical assessment of asserted preunderstandings, and a fusing of horizons may work against Indian advocates in some circunistances. ${ }^{466}$ For example, since practical

465. See, e.g., McNally v. United States, 483 U.S. 350, 362-77 (1987) (Stevens, J., dissenting) (meaning of the word "fraud" in criminal statute subject to evolutive interpretation); United States v. Locke, 471 U.S. 84, 117-29 (1985) (Stevens, J., dissenting) (statute requiring filing of claim "prior to Dec. 31" should be interpreted using coinunon sense to mean "by the end of the year").

466. Few would accuse Vine Deloria, Jr. of being insensitive to the interests of Indian selfdetermination. Yet consider his contextual assessinent of Oliphant:

The facts of the situation make the Indian argunent not only moot but demonstrate that it was based on an idea of sovereignty having little relation to actual reality.

The Port Madison Reservation where the tribe lived contained 7,276 acres, $63 \%$ of which, or approximately 4,584 acres, was owned by non-Indians. While 2,928 non-Indians lived on the reservation, only fifty Indians resided there. The factual situation, therefore, was somewhat bizarre. The attorneys for the Indians were arguing that fifty Indians, $1.7 \%$ of the reservation population, should have basic municipal jurisdiction over nearly 3,000 non-Indians, more than $98.3 \%$ of the population of the reservation. The doctrine of Indian 
reasoning takes tradition seriously (although not blindly), this approach is unlikely to produce any outright rejection of broad congressional power in federal Indian law. Yet, from the perspective of practical reasoning, the continuation of expansive (although not plenary, in the sense of absolute) congressional authority can help empower the Indian position in some cases. The Court in Oneida, for example, accoinplished a practical result by keeping the controversy alive despite the pressures of general legal principles, and essentially transferred it to the political arena. The background of congressional power also makes it easier for the Court to reach certain outcoines favorable to tribes, as in Crow Tribe and LaPlante. The Court in these cases had the luxury of allowing tribes breathing room to experiment with expansive tribal sovereignty without risking any substantial long-term costs (as might occur if, for example, the experiment was a failure, but no case that might restrict tribal sovereignty made its way to the Court for many years).

Congressional power also seems somewhat less pernicious from the contemporary viewpoint. From the Indian perspective, Supreine Court decisions, not congressional action, have produced the inost significant losses in the last two decades. ${ }^{467}$ Indeed, in 1987 Charles Wilkinson wrote that Congress had adopted no legislation over significant Indian opposition since the Indian Civil Rights Act of $1968 .{ }^{468}$ Congress' 1988 statute providing for some state cooperative role concerning reservation gambling operations ${ }^{469}$ weakens Wilkinson's point only shightly; the statute was a compromise between competing tribal and state interests, and not a unilateral imposition upon tribes of the states' point of view. ${ }^{470}$

sovereignty, perhaps relevant for a large reservation such as the Navajo with millions of acres of land and over 100,000 residents, was expected to control the court's thinking in defiance of the actual facts. Surely, here was an imstance of a doctrine run amok.

When attorneys and scholars come to believe that doctrines have a greater reality than the data from which they are derived, all aspects of the judicial process suffer accordingly.

Deloria, supra note 349, at 215 (footnotes omitted); see Climton, supra note 352, at 581-87 (Oliphant should have been decided on its facts, leaving open the question of tribal criminal jurisdiction over nonmembers in other settings).

467. See Ball, supra note 341, at 55-59.

468. See C. Wilkinson, supra note 6 , at 83.

469. Indian Gaming Regnlatory Act, 25 U.S.C. $\$ \S 2701-2721$ (1988). Among other things, the statute creates a federal National Indian Gaming Commission, id. $\S 2469$ (1988), and requires tribes and states to negotiate compacts governing certain gambling activities on Indian land. Id. $\$ 2710$ (1988).

470. The Court's decision in California v. Cabazon Band of Mission Indians, 480 U.S. 202 (1987), discussed at supra note 178, thus worked a practical result-by leading to a congressional accommodation of competing state and tribal interests rather than the unilateral inposition of nonIndian values.

Although it is impossible to know whether its suggestions will meet with any success, a recent major report of the Special Committee on Investigations of the Senate Select Committee on Indian Affairs reinforces the plausibility of taking a more berign view of Congress and Indian Affairs. The report calls for a new federalism for tribes, under which the federal Bureau of Indian Affairs would be abolished, with its funding and functions going to the tribes themselves. See SPECIAL COMM. ON 
One important lesson is that judicial decisions protecting tribal autonomy give tribes important bargaining chips for negotiation with federal and state governments. ${ }^{471}$ Legal scholars have, perhaps, too long assumed the primacy of judicial resolution of the continuing normative and empirical problems associated with our history of colonization. ${ }^{472}$

\section{CONCLUSION}

As this century draws to a close, federal Indian law occupies a place of renewed, if not unprecedented, importancc. Yet the Supreine Court's performance has frequently been disappointing. Foundationalist approaches have proved too hollow or too abstract to accommodate our colomal heritage with the human values of the late twentieth century. It may be time to abandon foundationalist theory, while accepting foundationalist concepts for what they can accomplish.

Both the traditional concepts and their newer, more critical competitors, such as international human rights norms and analogies to individual rights doctrines, will frequently be plausible presumptive doctrines. Indeed, Third World pressures related to international human rights could eventually change federal attitudes about tribal Indians. Given our traditions, however, courts are unlikely unilaterally to embrace these new concepts, just as they have never fully embraced the unilateral preunderstandings of colonization.

The antiformahist alternative of practical reason may hold more hope. The nature of practical reason makes it impossible to predict exactly how it would change federal Indian law, but some implications

INVEstigations of The Senate SElect Comm. ON INDian AfFairs, S. ReP. 216, 101st Cong., 1st Sess. 18 (1989). It may well be that the report will fade away. Even should that occur, the presence in the Senate of legislators with these views could at least help prevent the passage of future legislation harmful to tribes.

471. In this light, consider Williams v. Lee, 358 U.S. 217 (1959), discussed at supra text accompanying notes 181-83. Williams held that tribal courts have exclusive jurisdiction over a collection action on a debt owed by a reservation Indian to a non-Indian for a transaction entered into in Indian country. Ironically, fron the standponit of elenientary law and economics, the holding in Williams v. Lee appears to harm Indians; reducing the conventional enforceability of lending agrecnents will presumably make credit less available to tribal Indians. With Williams on the books, however, tribes may find ways to bargain away tribal court exclusive jurisdiction if states offer something deenied more valuable in return.

472. Vine Deloria, Jr. has suggested that it is ironic that, while some legal scholars were busy conceptualizing tribal sovereignty,

the practical world of Indians and members of Congress were working out a method for resolving disputes that accepted as a historical fact the sovereignty of Indian tribes. The difference here is actually immense, but it may escape the notice of people trained to believe that law reigns suprenie in the field of political institutions. Negotiation allows people to give and take, and they do not agree unless they feel they have done their very best to represent their case. The enotional feeling which participation in decision-nuaking provides generates a sense that solne measure of justice has been done.

Deloria, supra note 349, at 218. 
are clear. Practical reason would make some decisions that are difficult to defend on conventional grounds much easier to justify. Indeed, although the opinions poorly reflect it, the Court's refusal to follow obsolescent congressional expectations in Menominee Tribe (the termination case), Solem (the reservation diminishment case), Mitchell II (the allotment mismanagement sovereign immunity case), and Bryan (the Public Law 280 state tax case) are consistent with attention to context, a critical approach to preunderstandings, and the fusing of horizons-all endeavors that practical reason encourages. In other cases like Martinez (the tribal meinbership civil rights case), Oliphant (the tribal criminal jurisdiction case), and Cotton Petroleum (the non-Indian contractor state tax case), the Court's simphistic answers may evaporate under the scrutiny of practical reason, and much more information and analysis may be required. The general point emerging from these cases is that practical reason asks the questions relevant to understanding and reconstructing the legal treatment of tribal Indians as they are situated today. In a field where the Court has almost never even explicitly overruled a precedent, ${ }^{473}$ it is too late to rely upon the conceptualisins of old, and probably even past the tinie to rely upon conceptuahism, but nonetheless it is too soon to fall into the abject pessimism that critique is all there is.

473. See Frickey, supra note 30, at 1213. 